\title{
EDUCAÇÃO AMBIENTAL NA SERRA DO ITAPETY \\ MOGI DAS CRUZES - SP \\ CONSTRUINDO UMA AGENDA 21 LOCAL
}

MARIA HENRIQUETA ANDRADE RAYMUNDO

Dissertação apresentada à Escola Superior de Agricultura "Luiz de Queiroz", Universidade de São Paulo, para obtenção do título de Mestre em Recursos Florestais, com opção em Conservação de Ecossistemas Florestais.

\author{
PIRACICABA \\ Estado de São Paulo - Brasil \\ Março - 2002
}




\title{
EDUCAÇÃO AMBIENTAL NA SERRA DO ITAPETY \\ MOGI DAS CRUZES - SP \\ CONSTRUINDO UMA AGENDA 21 LOCAL
}

\section{MARIA HENRIQUETA ANDRADE RAYMUNDO}

\author{
Bióloga
}

Orientador: Prof. Dr. DALCIO CARON

Dissertação apresentada à Escola Superior de Agricultura "Luiz de Queiroz", Universidade de São Paulo, para obtenção do título de Mestre

em Recursos Florestais, com opção em Conservação de Ecossistemas Florestais.

\author{
PIR A C I C A B A \\ Estado de São Paulo - Brasil \\ Março - 2002
}




\section{Dados Internacionais de Catalogação na Publicaçăo (CIP) DIVISĀO DE BIBLIOTECA E DOCUMENTAÇĀO - ESALO/USP}

\section{Raymundo, Maria Henriqueta Andrade}

Educaçăo ambiental na Serra do ltapety, Mogi das Cruzes - SP, construindo uma Agenda 21 local / Maria Henriqueta Andrade Raymundo. - Piracicaba, 2002.

169 p. : il.

Dissertaçao (mestrado) - E Escola Superior de Agricultura Luiz de Queiroz, 2002. Bibliografa.

1. Educaçıo 2. Proteçıo ambiental 3. Psicologla ambiental 4. Sociologia 1. Titulo

CDD 333.707

"Permitida a cópia total ou parcial deste documento, desde que citada a fonte - $O$ autor" 


\section{DEDICATÓRIA}

Ao Caio Vinícius, minha doce criança, responsável pelo meu crescimento e pelas transformações das dores e tristezas em força, alegria e satisfação;

À minha querida vó Henriqueta, com orgulho pela sua vida de bons exemplos de coragem e amor;

Aos meus queridos pais, Elza e Luiz sempre dedicados, responsáveis pela minha formação;

Ao Marcos Sorrentino, ser humano excepcionalmente admirável, exemplar em suas ações pessoais e profissionais estabelecidas com ética, sabedoria, carinho, sinceridade, coragem e muita dedicação;

À Cristina Gaiotto, irmã querida, guerreira e generosa, dedicada intensamente ao meu crescimento pessoal $e$ profissional;

Ao Faustino José Ferreira, pela magia do amor intenso e feliz, transformando toda sua sensibilidade e carinho em generosas condições para realização desta pesquisa. 


\section{AGRADECIMENTOS}

Ao Marcos Sorrentino, professor, orientador, amigo, por confiar em minha capacidade, permitindo a realização desta pesquisa;

Ao meu orientador Dálcio Caron, por tornar possível a viabilização do mestrado, sempre preocupado com meu bem estar, atencioso e generoso;

À minha família: Elza, Luiz, Henriqueta, Cristina, Luiz Antonio, Cidinha, Zezé, Erasmo, Cláudio e Isabel pela extremada compreensão e apoio nesta pesquisa;

Ao Faustino José Ferreira, que propiciou as condições materiais e sentimentais para realização deste projeto;

À Ana Paula Coati e Milena Coati, amigas, irmãs e família encontrada e formada em Piracicaba, com a mais pura e doce receptividade e doação;

Aos ministrantes do curso para os alunos universitários, todos dedicados com extrema abdicação e atenção: Sueli Antonia Nicolau, Jurandyr Ferraz de Campos, Vitor Arai, Vivian G. de Oliveira, Marcus Vinícius Monteiro dos Santos; Rosana Martins, José Roberto Manna de Deus; Marcos Sorrentino e Antonio Vitor Rosa;

Ao professor Pedro Tomasulo, pela atenção e realização de palestra para todos os grupos da pesquisa;

À admirável vereadora Sonia Sampaio, com a ética da política séria e competente, juntamente com seus brilhantes assessores Rudnei de Oliveira, Cid Câncer e Eliseu Piacentin, pelo apoio logístico e disponibilização de documentos;

Ao José Roberto Manna de Deus, meu amigo de coração, por "tudo", incluindo o carinho e empenho nas atividades que se envolveu, além de propiciar parte da logística deste trabalho; 
Ao Marcio Lunardi, meu amigo fiel, que viabilizou tantas vezes, de forma desprendida, as atividades desta pesquisa deixando seu carro disponível;

À minha prima Marilda Miani, pelo carinho e generosidade presenteando-me com o computador fundamentalmente necessário neste trabalho;

Às amigas, irmãs e companheiras de mestrado, Vivian Gladys e Lilian Vendrametto, pela união e solidariedade em todas as etapas do mestrado;

À Alecsandra Tassoni, estagiária e amiga de todas as horas, das mais engraçadas às mais tensas; sempre atenciosa e dedicada;

À Daniela Soares, estagiária e amiga, pelo carinho e dedicação constante na organização do material bibliográfico;

Aos queridos estagiários desta pesquisa e também do Programa de Uso Público do Parque, pela dedicação e desprendimento;

Ao Cemasi, por entender e permitir meu afastamento para a conclusão do mestrado, além de propiciar apoio logístico;

À Vivian Moreno e Anderson Pagoto, pela colaboração paciente e disposição em várias atividades desta pesquisa;

A professora Carmem Lúcia Rodrigues, pela atenção nas leituras na fase final deste trabalho, apontando varias recomendações com grandes estímulos;

A professora Eda Tassara, pela gentileza e dedicação na leitura deste trabalho, com reflexões e recomendações;

Aos promotores de justiça: Dr. Marcus Vinícius Monteiro dos Santos, Dr. Fernando de Oliveira Castro e Dr. Ricardo Augusto Montemor, pelas atenciosas e dedicadas colaborações;

Ao Marlon de Melo, estagiário e amigo sempre dedicado e atento às necessidades do projeto;

Ao professor Valter de Morais, pela paciente e cuidadosa revisão final do texto;

Às amigas carinhosas e dedicadas, Celly, Berta e Angelita sempre presentes nas tarefas desta pesquisa;

Á Claudinéia Clemente, pela colaboração nas diversas atividades, disponibilizando materiais e facilitando meu acesso na Universidade Braz Cubas; 
Á Organização Bio Bras: Nadja e Adriana pelos documentos cedidos e apoio material;

Ao Fernando pela colaboração empenhada no auxílio à formatação gráfica deste material;

À Comissão da Agenda 21 da Serra do Itapety, pelo empenho e força na realização das atividades, acreditando ser o caminho para nossa conquista de uma vida melhor;

À todos os sujeitos desta pesquisa, pela disposição, atenção e colaboração;

Por fim, agradeço ao "Novo Encanto" na minha vida, que surgiu maravilhosamente numa tempestade, trazendo-me novo brilho e inspiração, com todo carinho e dedicação, tornou possível o complementar essencial desta pesquisa. 


\section{SUMÁRIO}

Página

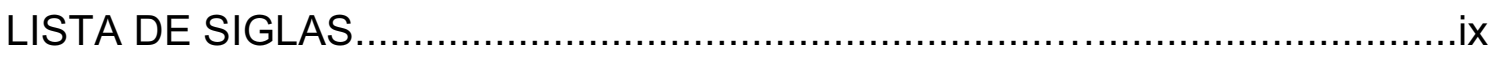

RESUMO

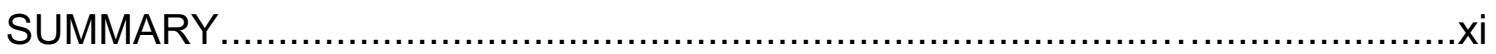

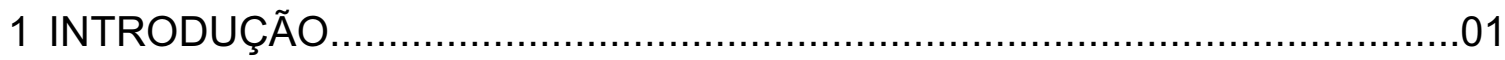

1.1 Apresentação

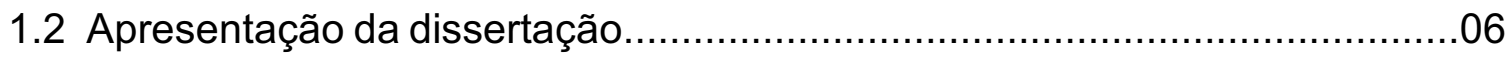

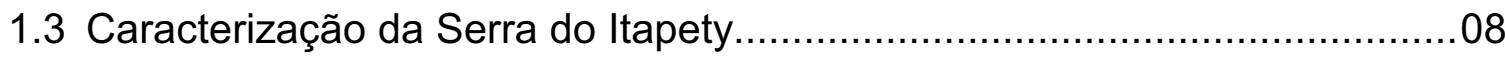

1.4 Educação ambiental e participação....................................................12

1.5 Agenda 21 local e educação ambiental....................................................19

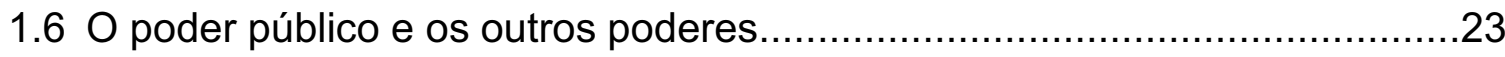

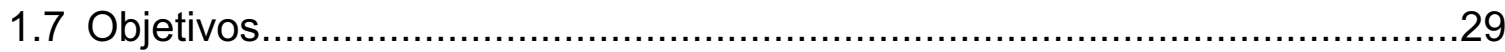

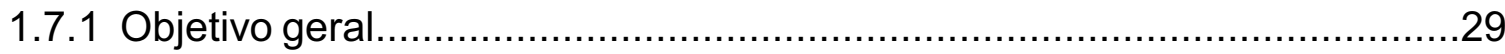

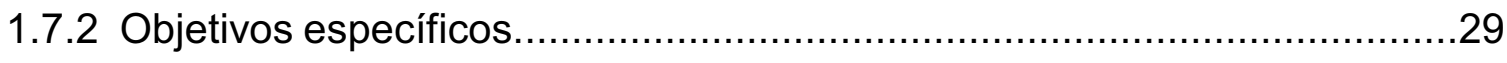

2 METODOLOGIA

2.1 Metodologia qualitativa e intervenção social............................................30

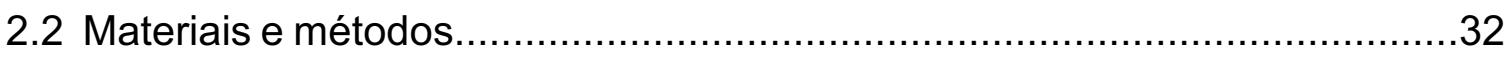

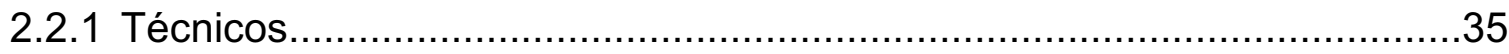

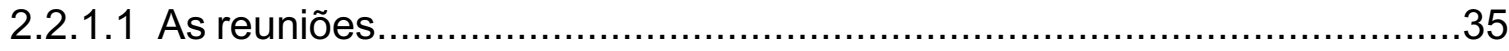

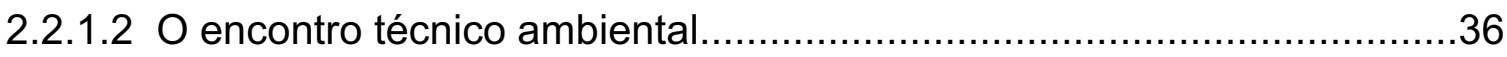

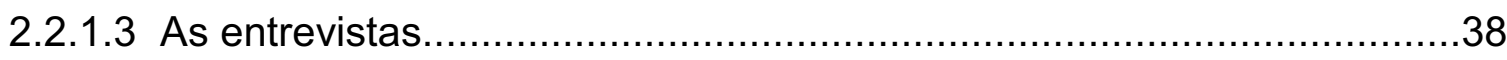

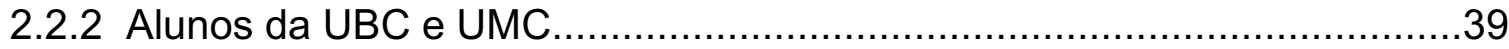

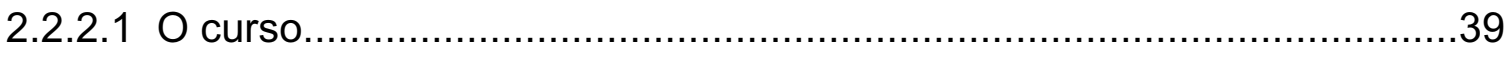

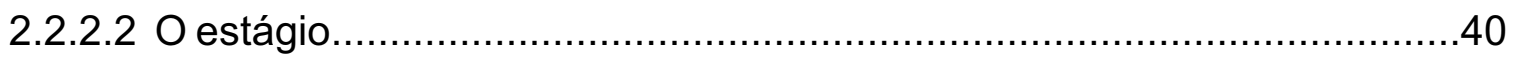




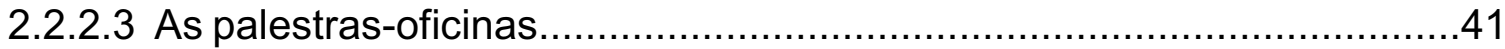

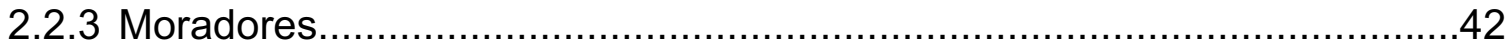

2.2.4 Professores dos ensinos fundamental e médio de Mogi das Cruzes........43

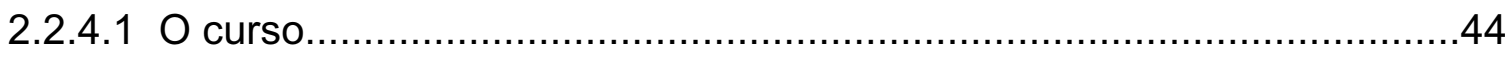

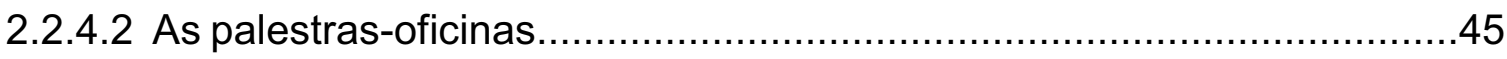

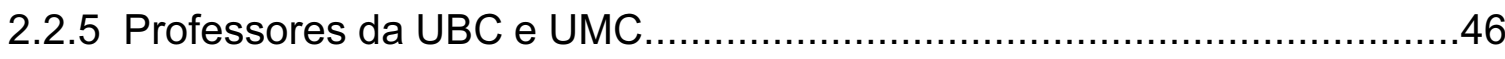

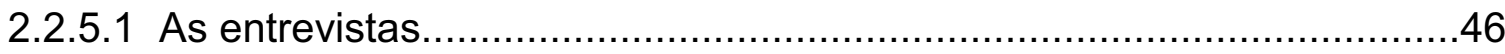

2.2.6 Vereadores da Câmara Municipal de Mogi das Cruzes..........................47

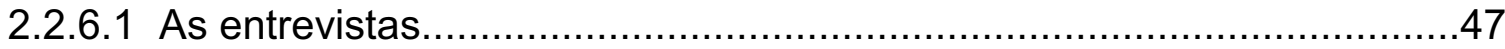

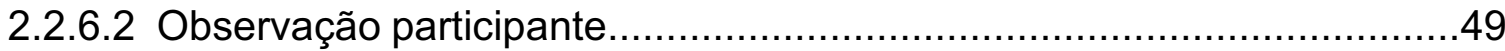

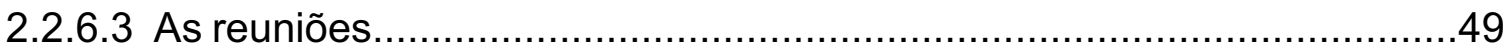

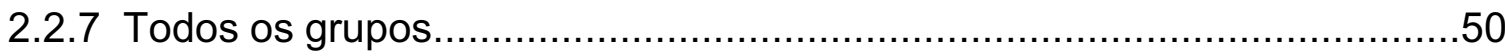

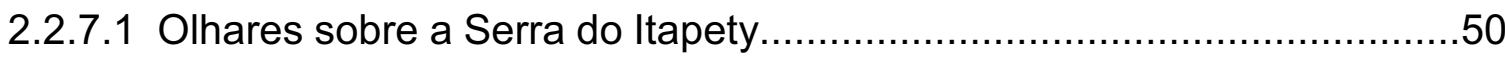

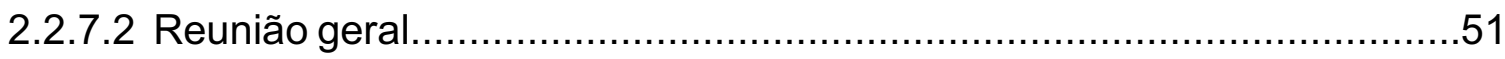

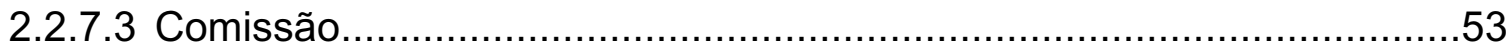

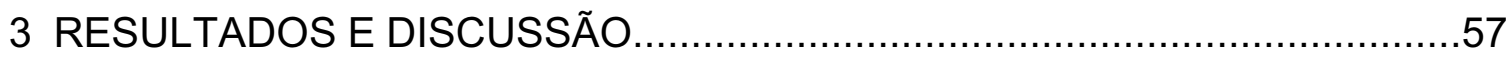

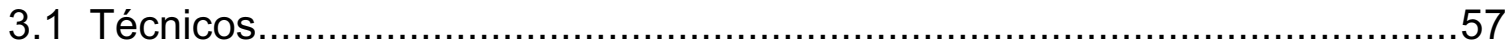

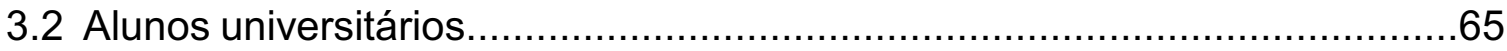

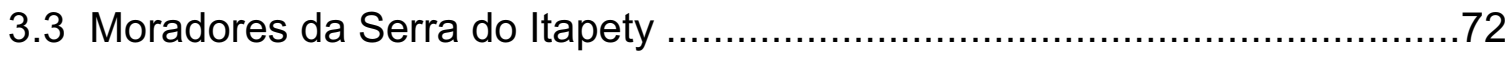

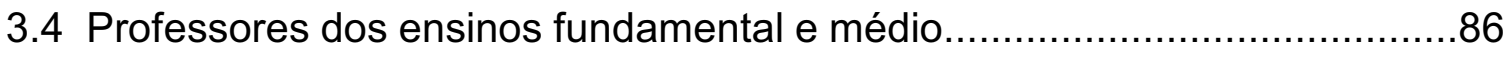

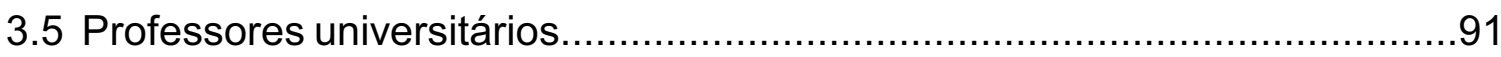

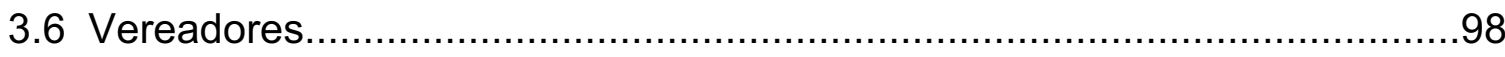

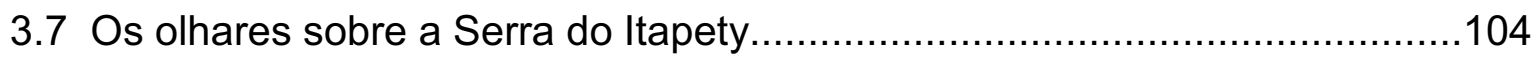

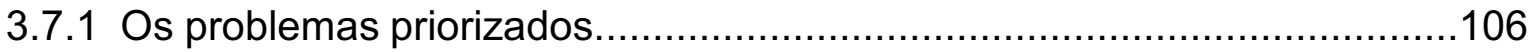

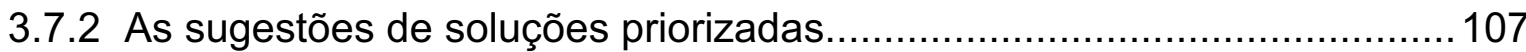

3.7.3 A Comissão da Agenda 21 da Serra do Itapety..................................... 109

3.7.3.1 A sistematização dos olhares sobre a Serra do Itapety......................... 112

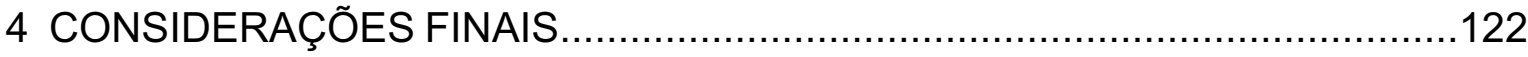

4.1 Das manifestações dos grupos à construção da Agenda 21.......................122

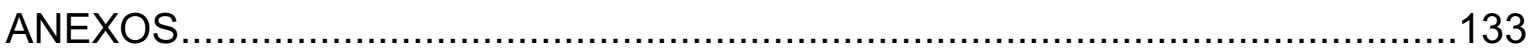

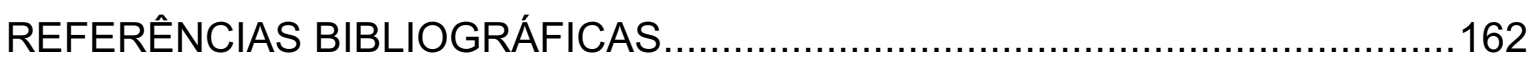




\section{LISTA DE SIGLAS}

CEMASI - Centro de Monitoramento Ambiental da Serra do Itapety

CEV - Comissão Especial de Vereadores da Agenda 21 Local de Mogi Das Cruzes

ONG - Organização Não Governamental

UBC - Universidade Braz Cubas

UMC - Universidade de Mogi das Cruzes 


\title{
EDUCAÇÃO AMBIENTAL NA SERRA DO ITAPETY MOGI DAS CRUZES - SP CONSTRUINDO UMA AGENDA 21 LOCAL
}

\author{
Autora: MARIA HENRIQUETA ANDRADE RAYMUNDO \\ Orientador: Prof. Dr. DÁLCIO CARON
}

\section{RESUMO}

\begin{abstract}
Esta pesquisa é construída a partir da deflagração de processos educativos geradores de participação, visando a melhoria da qualidade de vida e conservação de recursos naturais, históricos e culturais da Serra do Itapety, uma área de Mata Atlântica, existente no município de Mogi das Cruzes, SP. Variados segmentos da sociedade civil e poder público se envolveram para elaborar uma Agenda 21 local, possibilitando a realização de uma pesquisa qualitativa, percorrendo o caminho do fortalecimento de sujeitos que constróem sua própria história. São analisadas as formas de participação dos diferenciados atores e a compreensão que os moradores da Serra do Itapety têm sobre suas realidades. Os resultados configuram-se numa diversidade de olhares técnicos, acadêmicos, políticos e populares, entre outros, que entrelaçados organizam-se reflexivamente para a viabilização das sugestões, ações e desejos apontados pelos envolvidos na construção da Agenda 21 Local.
\end{abstract}




\title{
ENVIRONMENTAL EDUCATION IN THE ITAPETY MOUNTAIN RANGE, CITY OF MOGI DAS CRUZES, SÃO PAULO STATE, BRAZIL, AS A WAY TO CONSTRUCT A LOCAL AGENDA 21
}

\author{
Author: MARIA HENRIQUETA ANDRADE RAYMUNDO \\ Adviser: Prof. Dr. DÁLCIO CARON
}

\section{SUMMARY}

A research technique is built based on educational process that aims public involvement to develop subsidies for better conditions of the quality life for the community, as well as the conservation of natural, historical and cultural resources of the Itapety Mountain Range - a Atlantic Forest area, located the municipality of Mogi das Cruzes, São Paulo State, Brazil. Different sectors of civil society and government are involved to create a local Agenda 21. This situation permits the development of a qualitative research, resulting in a series of actions that aims to create a stronger conscientiousness of the importance of natural resources and the quality of life. The level of comprehension of local residents of Itapety Mountain Range about their environment and the ways and reasons of participation of other people in the process of building up the Agenda 21 were analised. The result of this analysis shows the existence of a wide range of opinions, perceptions and sugestions, defined as technical, academical, political and popular views. These views interwoved in a reflexive approach should produce a viable construction of the local Agenda 21. 


\section{INTRODUÇÃO}

"O predomínio da razão e da objetividade na história das idéias como pressupostos epistemológicos, definidores da natureza humana, impôs uma ontologia e uma epistemologia negativas da subjetividade e dos seus correlatos, como afetividade e imaginação. Nessa perspectiva analítica, subjetividade é da ordem das paixões, considerada uma variável independente da natureza humana que pode e deve ser anulada para garantir a plena participação racional na sociedade e, consequentemente, manutenção da ordem social. Já no paradigma da positividade, a subjetividade deixa de ser força incontrolável, antagônica

à participação racional e objetiva e passa a ser constituinte dela. O que equivale a afirmar que não há participação sem subjetividade, nem subjetividade sem participação. Ambas são fenômenos da mesma substância, de forma que, para mudar a qualidade da participação, é preciso mudar a ontologia da subjetividade."

(Bader Sawaia)

\subsection{Apresentação}

A subjetivação de meu projeto tem nome de "Caio Vinícius", aquele que sempre me faz ver cores, flores e amores nos encantos e dores da realidade, como reação aos sabores e dissabores da vida, numa construção dia a dia do futuro, que não é amanhã, e sim agora. 
$\mathrm{Na}$ tentativa de entender o mundo particular do meu filho, deixei de lado a idéia do teatro, da dança, ou da publicidade e fui, aos 23 anos, para um curso de Biologia, julgando que passaria a entender tudo acerca de neurônios.

No meio do caminho, atordoada com a fisiologia e anatomia neurológica, fui me desviando desta busca, que para mim tornava-se irracional, diante da felicidade traduzida pela bela melodia que o silêncio de meu filho suscitava.

Com o aval desta felicidade, e como uma mocinha má, fui à luta, procurando aquilo que realmente me interessava participar, profissional e pessoalmente.

Já conhecia o Parque Natural Municipal da Serra do Itapety desde a infância, como quase todo mogiano da minha idade, isso não bastasse, no curso de Biologia ninguém escapava de uma aula de zoologia ou ecologia naquelas matas. Assim, depois de anos, voltei ao Parque e fiquei maravilhada, não com o estudo, mas com o Parque em si.

Após aquela aula, passei a visitá-lo constantemente, por tantos e pretensos motivos: alegria, tristeza, aula, piquenique, caminhadas, enfim, por tudo e por nada.

Não me contentando, tratei de conseguir um estágio no Parque, através do Centro de Monitoramento Ambiental da Serra do Itapety - CEMASI instituição de pesquisa em conservação da biodiversidade e educação ambiental - pertencente a Universidade Braz Cubas (UBC) e Universidade de Mogi das Cruzes (UMC), instituições privadas do município.

$\mathrm{Na}$ hora de optar pela área em que gostaria de estagiar: fauna, flora ou educação ambiental? Mesmo sem ter noção do que representava, escolhi imediatamente educação ambiental. Fui pela intuição e simpatia.

Assim, houve uma química perfeita: beleza, tranqüilidade, harmonia, floresta, gente, educação, e talvez aquilo de que mais entenda, conversar. Tratava-se de educação ambiental conservacionista, voltada principalmente para crianças e adolescentes, visando à conservação do Parque, área de Mata Atlântica. 
Após 6 meses de estágio, fui convidada para trabalhar como assistente do coordenador técnico da instituição, um jovem aparentemente "maluco", sobre quem eu lia nos jornais locais por curiosidade, desde minha adolescência.

Claro que aceitei imediatamente, também sem noção exata do que teria a fazer.

O meu primeiro trabalho foi administrativo, burocrático, ficando por 10 dias alojada no Parque (junto de meu filho), para colocar em ordem um trabalho atrasado de 2 anos.

Não via problemas nisto, o melhor estava chegando, meu coordenador, bem articulado política e tecnicamente, criador do CEMASI, responsável direto pelo envolvimento da Prefeitura Municipal de Mogi das Cruzes nos trabalhos de conservação do Parque, foi mostrando-me, na teoria e na prática, os caminhos e descaminhos em torno da problemática ambiental mogiana.

Foram 3 anos ao lado de José Roberto Manna de Deus (coordenador técnico), que me fez crescer e enxergar sempre o que queria para minha vida, e também para vida do Parque e de toda a Serra do Itapety.

Nestes 3 anos, pude fazer um detalhado levantamento histórico das ações políticas e acadêmicas do município para a Serra.

Participei administrativamente da elaboração do Plano de Manejo da área e me envolvi ativamente nos inúmeros encontros e confrontos existentes - cada um com uma longa história - para sua conservação. Envolvendo Polícia Militar, Bombeiros, Prefeitura Municipal, Câmara Municipal, Imprensa, ação judicial, Ministério Público em várias reuniões.

E a educação ambiental conservacionista? Esta eu abandonei quando iniciei os trabalhos com José Roberto.

Depois de tantas brigas pela Serra do Itapety e também pelo CEMASI, resolvi buscar um pouco de fundamentação teórica, fazendo um curso de especialização em Educação Ambiental.

Voltei então para a educação ambiental conservacionista, desta vez em outra área, longe da Serra do Itapety, como consultora da Votorantim Celulose e 
Papel- VCP. Foi uma boa experiência, além de propiciar uma bolsa que me permitia pagar o curso de especialização.

Paralelamente, continuava com alguns trabalhos com José Roberto, como organização de cursos em conservação e manejo de áreas naturais protegidas, palestras para alunos universitários e algumas outras atividades.

Após 2 anos com a VCP, tive a oportunidade de voltar ao Parque, desta vez como coordenadora do seu Programa de Uso Público. Função que desempenho até hoje pelo CEMASI.

Cheia de sonhos e desejos, feliz por voltar àquela área, da qual tivemos que nos afastar por motivos políticos durante 1 ano e meio, iniciei um trabalho de educação ambiental com os visitantes e também com os alunos universitários estagiários do Programa.

Nesta época, eu já conhecia Marcos Sorrentino, responsável pelo meu despertar na educação ambiental.

Logo que ouvi falar dele (1994), quis saber mais. $\mathrm{Na}$ primeira oportunidade ao vê-lo em palestra, fiquei encantada e concluí: é isso o que eu quero, em que acredito, de que preciso!

A partir daí passei a acompanhá-lo em tudo que me era possível; ler tudo que escrevia. E em minhas modestas palestras e reuniões, era inevitável, eu precisava falar dele e indicá-lo como leitura obrigatória para quem quisesse trabalhar com educação ambiental, não a conservacionista.

Encontrei aí os empecilhos das correntes da educação ambiental. Não fui bem aceita, pois falava de amor, de paz, de política, de cidadania, e o CEMASI não estava me compreendendo.

Suponho que a instituição me considerava uma louca, que minhas considerações sobre o Parque, a conservação, a fauna e a flora lhe soavam totalmente descabidas.

Entretanto, para aperfeiçoar "minhas loucuras" sobre educação ambiental, fui fazer na ESALQ em 1996, a disciplina de Marcos Sorrentino na 
pós graduação, uma experiência maravilhosa, mas que, diga-se de passagem, foi conseguida com muita insistência.

Neste caminho, fui tomando consciência, cada vez mais, de que realmente não era a educação ambiental conservacionista do Parque que conservaria a Serra do Itapety, que não haveria possibilidade de garantir a qualidade de vida dos moradores e muito menos estender isto ao restante da população de Mogi das Cruzes.

Decidi, então, buscar uma ação mais abrangente e eficaz, assim, sempre com o referencial Sorrentino, construiu-se a idéia desta pesquisa/intervenção.

Apesar de todas as limitações materiais, formais, políticas, ideológicas e filosóficas minhas e/ou de tudo e todos envolvidos, apresento esta pesquisa resultante de esforço coletivo e sinto-me feliz por ter sido inteira e intensa no mínimo que fiz.

"Para ser grande, sê inteiro:

nada teu exagera ou exclui.

Sê todo em cada coisa.

Põe quanto és no mínimo que fazes.

Assim em cada lago a lua toda

brilha, porque alta vive."

(Ricardo Reis - heterônimo de Fernando Pessoa) 


\subsection{Apresentação da dissertação}

O interesse desta pesquisa centra-se na compreensão sobre processos organizacionais e participativos, deflagrados e fundamentados por ação educacional, que visa contribuir para a melhoria da qualidade de vida e conservação de recursos naturais. Tomam-se como atores, grupos da sociedade civil e do poder público de Mogi das Cruzes que buscam integração através da construção de uma Agenda 21 Local.

A Agenda 21 como um fim desencadeador de meios para o desenvolvimento de educação ambiental que estimule e facilite a participação e organização de variados segmentos da sociedade com diversificados interesses em torno da Serra do Itapety.

Uma Serra do Itapety, que traz ao longo de sua história toda a complexidade da sociedade representada em sua política, educação, ciência e desenvolvimento econômico como fatores determinantes do processo de degradação ambiental e social explicitados neste local.

Da conservação de biodiversidade à construção de cidadania, do humilde morador ao promotor de justiça, das ações às reflexões, da intervenção social ao conhecimento científico... estes são alguns pontos que esta pesquisa modestamente percorre.

Esta dissertação apresenta-se dividida em 4 capítulos: introdução; metodologia; resultados e discussão; e as considerações finais.

Traz como centro de discussão a participação individual e coletiva a partir de reflexões sobre educação ambiental, vista como possibilidade de construção da cidadania para emancipação de sujeitos. A pesquisa aqui descrita, construiuse principalmente nas intervenções que, subsidiaram, fundamentaram e permitiram a participação de diversificados atores da sociedade civil e do poder público em processos educativos, técnicos e políticos visando tomar decisões sobre nossas vidas. 
Trata-se da utilização da Agenda 21, como meio e fim de alcançar a melhoria da qualidade de vida e conservação de recursos naturais, históricos e culturais da Serra do Itapety, além de propiciar a produção participativa de conhecimentos.

Desta forma ainda neste capítulo 1 apresento a área da Serra do Itapety, com informações gerais, sobre seu histórico, uso, ocupação, potencialidades e problemas.

Em seguida apresento alguns referenciais teóricos de conceituação e histórico, e também aqueles adotados e compartilhados por esta pesquisa em torno dos temas:

Educação Ambiental e Participação; Agenda 21 e Educação Ambiental; Poder Público e outros poderes.

Este capítulo é finalizado com os objetivos geral e específicos da pesquisa, que foram construídos com base no referencial teórico e características gerais da área.

O capítulo 2, traz o referencial teórico da metodologia qualitativa e intervenção social, passando pelo incrementalismo articulado. Aqui são descritos os atores e grupos envolvidos nesta pesquisa, além do detalhamento das técnicas, estratégias e atividades realizadas com os mesmos.

No capítulo 3, aponto os resultados e discussões em torno de discursos e ações, numa manifestação de subjetivações que levaram a diversas formas de participação e ausência de participação; sobre o diagnóstico dos moradores da Serra do Itapety, além das visões diferenciadas sobre os problemas e possíveis soluções para a área.

Encerrando a dissertação, apresento o capítulo 4 trazendo as considerações finais com uma análise geral da participação dos grupos e suas inter-relações. 


\subsection{Caracterização da Serra do Itapety}

Em Mogi das Cruzes, município com área de $721 \mathrm{Km}^{2}$, população em torno de 350.000 habitantes, situado a $58 \mathrm{~km}$ da capital do Estado de São Paulo, localiza-se a Serra do Itapety.

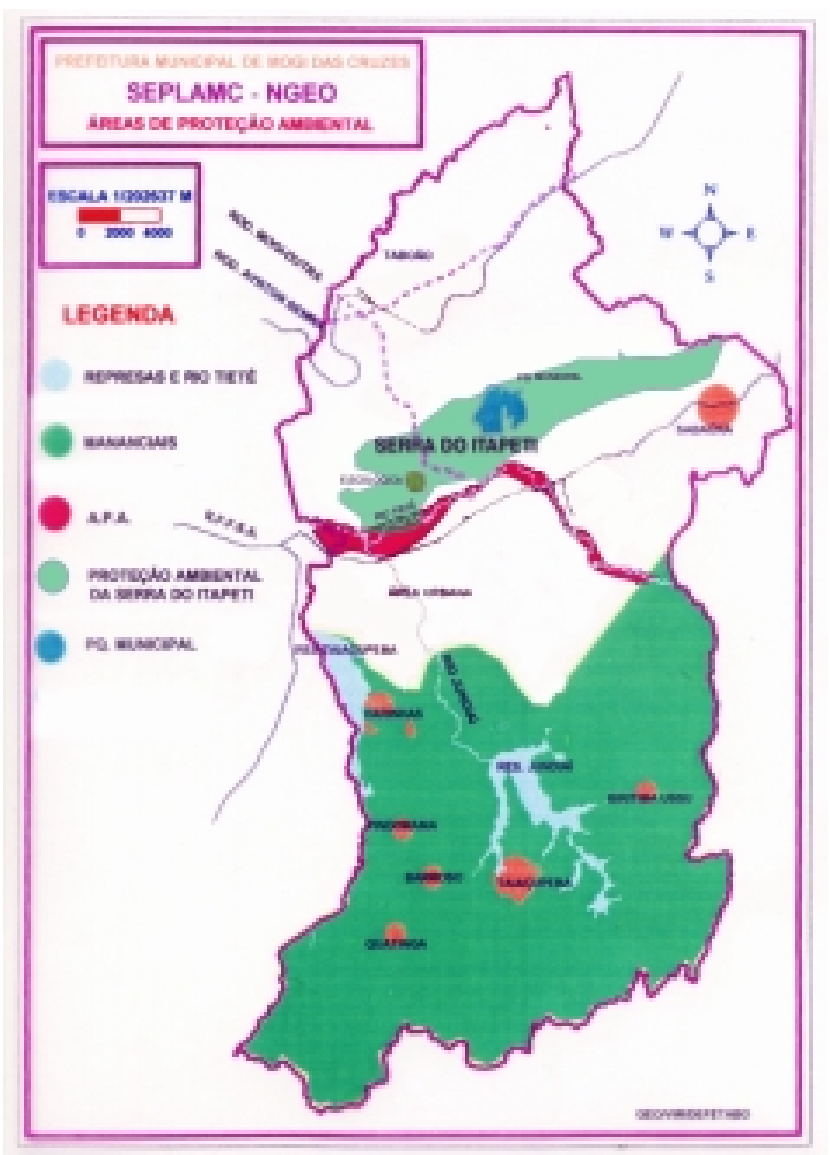

Figura 1 - Mapa de Mogi das Cruzes localizando a Serra do Itapety.

Fonte: Prefeitura Municipal de Mogi das Cruzes.

"A Serra do Itapety, contida quase que por inteiro no território do município, caracteriza-se como serra isolada, resíduo de antigas superfícies mais elevadas" (Plano Diretor, 2000, p.24). 
Com 5200 hectares esta Serra cruza transversalmente no sentido lesteoeste toda a área do município, tornando-se um divisor de relevos, além de ser um divisor de águas das bacias dos rios Tietê e Paraíba.

Considerada um dos últimos remanescentes de Mata Atlântica da região metropolitana de São Paulo, a Serra do Itapety, apresenta-se com alta biodiversidade, representada entre outros, por várias espécies ameaçadas de extinção como o Callithrix aurita, Felis sp, Tinamus solitarius, Penelope obscura e etc (Manna de Deus et al, 1995).

Com a identificação de mais de 250 espécies de fauna, constatou-se que esta área é um grande refúgio de animais silvestres, sendo isto um fator importante para sua conservação, visto que " $70 \%$ de toda biodiversidade é composta de espécies animais" (SMA-SP, 1996, p.17).

É preciso que não só a biodiversidade da Serra do Itapety seja considerada, mas também, a riqueza de seus aspectos histórico-culturais, com a evidenciação de vários sítios arqueológicos, bem como construção religiosa datada do século XVII (Andreata,1991). ${ }^{1}$

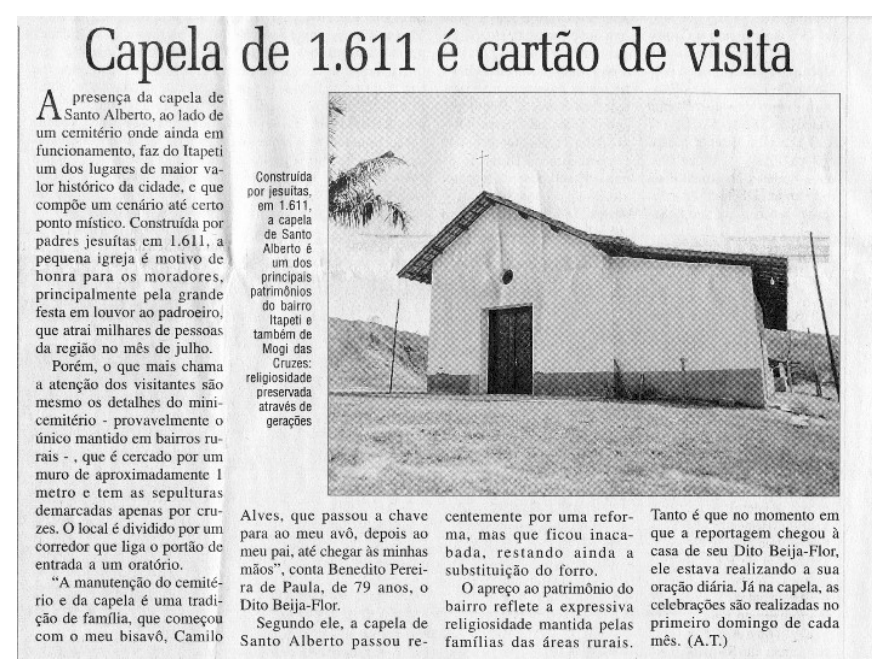

Figura 2 - Capela de Santo Alberto.

Fonte: Jornal Mogi News / 19/08/2001. 
Outro ponto importante na história da Serra do Itapety, é o fato do município de Mogi das Cruzes ter sido abastecido por seus ricos mananciais no período entre 1911 a aproximadamente 1950, sendo o sistema de captação desativado quando este se tornou insuficiente diante da expansão acelerada da cidade.

As áreas adquiridas na Serra do Itapety pela Prefeitura Municipal para o abastecimento de água do município no período mencionado, são mantidas até hoje, devendo-se a isto, em parte, a atitude do prefeito da época, que recebendo proposta para vender as terras, recusou-se com a seguinte argumentação:

"ponderando bem a matéria tratada nestes autos, cheguei 'a conclusão de que não há interesse para a municipalidade a venda das matas em apreço, pois sua localização é situada onde já tem havido devastação para o consumo de lenha, apresentando, certas áreas, o aspecto de terra devastada, não convindo, portanto, corroborar a devastação das terras do patrimônio municipal" (Manna de Deus et al, 1995, p.9).

Ressalta-se ainda outro aspecto a ser considerado na preservação e conservação da Serra do Itapety: seu valor paisagístico e estético, que embeleza e envaidece os mogianos.

De acordo com Alves (1999, p.22), "as pessoas se convencem muito mais pela imagem da beleza que pela verdade da ciência. A beleza pode seduzir o povo a amar a natureza, preservar a saúde, respeitar a vida..."

Todos os grupos envolvidos nesta pesquisa destacaram com orgulho prioritário a beleza que a Serra representa, independente de qualquer valor científico, econômico, político ou social que a mesma possa ter.

A Serra do Itapety está sob a proteção da Lei Estadual 4.529 de $18 / 01 / 1985^{2}$, que trata do uso e ocupação do solo, dividindo-a em dois tipos de zonas: zona de preservação ecológica e zona de proteção ambiental.

\footnotetext{
${ }^{1}$ Resumo apresentado pela autora na VII Reuniâo Científica da Sociedade de Arqueologia Brasileira na Universidade Federal da Paraíba em 1991

${ }^{2}$ Lei Estadual 4529/85 que regulamenta o uso e ocupação do solo na Serra do Itapety
} 
Este zoneamento define, entre outras coisas, o tipo de uso e as modalidades de parcelamento do solo permitidos em cada ponto da Serra do Itapety. Surge a partir daí, os conflitos pela ausência de fiscalização que permitiu ao longo dos anos a ocupação irregular segundo esta lei.

$\mathrm{Na}$ Serra do Itapety, existem 2 áreas naturais protegidas - Estação Ecológica do Itapety e Parque Natural Municipal da Serra do Itapety.

A Estação Ecológica do Itapety, de acordo com o decreto estadual 26.890 de 12/02/1987, possui 89,7 hectares é administrada pelo Instituto Florestal da Secretaria Estadual de Meio Ambiente do Estado de São Paulo - SMA -SP.

O Parque Natural Municipal da Serra do Itapety, possui 352,3 hectares é administrado através de um convênio entre Prefeitura Municipal de Mogi das Cruzes e o CEMASI.

Resta, portanto, no entorno destas 2 áreas, 4758 hectares ocupados por propriedades que variam entre pequeno, médio e grande porte com utilização residencial e/ou comercial.

Sem dados precisos da população existente na Serra do Itapety, calculase que na sua região, existam em torno de 6000 habitantes, com contrastes visíveis, passando por poucos moradores antigos que vivem em pequenas casas e sítios de construções simples, moradores antigos e recentes de casas e mansões luxuosas e por fim os moradores dos últimos 10-15 anos de propriedades simples até as miseráveis que vem invadindo a área.

Independentemente do nível sócio-econômico da propriedade, o problema é que a maioria encontra-se irregular de acordo com a lei 4529/85. Estando algumas propriedades sob processos de ação civil do Ministério Público do Estado de São Paulo, o que provocou no decorrer desta pesquisa, uma série de discussões e avaliações sobre a competência e eficiência dos órgãos responsáveis do poder público.

A ocupação na Serra do Itapety ocorreu de forma não planejada, devido à expansão urbana do município com fatores políticos e sócio-econômicos excludentes, onde a elevação demográfica aconteceu principalmente nos 
últimos 15 anos, acelerando o processo de degradação ambiental do local, como também a diminuição da qualidade de vida dos moradores.

Hoje, a Serra do Itapety tem seu patrimônio biológico e histórico-cultural, além dos seus importantes aspectos paisagísticos, completamente ameaçados por constantes agressões ambientais como: caça, extração de plantas, desmatamentos, queimadas, ocupações irregulares entre outros, que esta pesquisa considera frutos de um descaso do poder público e ausência de participação da sociedade civil na pressão e tomada de decisões.

Considerou-se aqui a urgência da necessidade de ações com a participação do poder público e da sociedade organizada no comprometimento com a conservação da Serra do Itapety, visando também à melhoria da qualidade de vida de sua população.

\subsection{Educação ambiental e participação}

Para Saviani (1994) ${ }^{3}$, a educação ambiental está posta desde as origens, como nessas origens a educação não se fragmentava, ela é desconsiderada. Porém, tratando-se do sentido próprio da palavra, esta origem se afirma baseada na relação de dependência do homem com a natureza, estabelecendo aí sua educação no ambiente e pelo ambiente.

Sorrentino (1993, p.7) também menciona estas origens da educação ambiental ao citar que "antepassados ilustres como Rousseau e Freinet, indicavam a natureza e o meio como recursos educativos", representando assim, a existência de propostas antigas de uma educação para o meio e a partir do meio."

Educação ambiental como uma educação diferenciada é estabelecida quando sua problemática central surge na sociedade moderna, com a

\footnotetext{
${ }^{3}$ Transcrição de fita cassete da palestra apresentada pelo autor no Seminário: Educação e Meio Ambiente realizado pela Secretaria Estadual do Meio Ambiente de Sâo Paulo.
} 
dominação da natureza pelo homem, que em sua ignorância, só percebe o problema quando sua própria existência é ameaçada (Saviani, 1994).

Para Sorrentino (1993, p.7) a educação voltada para a questão ambiental tem o seu papel diferenciado quando ocorre a popularização da problemática ambiental, onde é percebido que "não basta preparar o indivíduo para transformar a natureza e o meio em benefício seu e da espécie. É necessário entender 0 ambiente não somente como um meio para satisfazer as necessidades humanas, mas como o "meio ambiente" do ser humano que condiciona a própria sobrevivência."

Saviani (1994) em análise histórica das origens e concepções da educação, diz que a educação ambiental "é um conceito integral e amplo que abarcaria a educação no seu conjunto".

De acordo com Tassara (1995, p.40), "a educação ambiental independente de seu compromisso ideológico ou propósitos aos quais se vinculam as iniciativas delas emanadas está inscrita no cerne da educação científica coincidente com a educação."

Crespo (2000, p.213-215), considerando que uma das concepções da educação ambiental a situa dentro da educação geral com seus dramas e desafios, faz uma análise da prática educacional inserindo a educação ambiental dentro de 2 grandes modelos - o tecnicista e o humanista:

"No primeiro modelo a educação ambiental, tem de ser vista como disciplina ou parte de uma disciplina, e aí a Biologia ou Geografia como as disciplinas vocacionadas. Aqui são valorizados os conceitos científicos da ecologia e a natureza é vista como recursos naturais renováveis e não - renováveis. A consciência ambiental resume-se em estabelecer cientificamente uma utilização racional destes recursos. Enquanto que no modelo humanista a educação ambiental é vista como uma discussão ética em primeiro plano e como um lugar onde se pode questionar de maneira circunstanciada o modelo de sociedade vigente e 
sua sustentabilidade a médio e longo prazos. O discurso mediador é ético-filosófico e a ciência apenas vem reforçá-lo através dos fatos que é capaz de construir."

Conforme avaliação de Sorrentino (1998, p.30), a educação ambiental pode ser classificada em 4 grandes correntes cada uma com seu processo histórico delineador, permanecendo sua essência na atualidade:

“1) Conservacionista: bastante presente nos países mais desenvolvidos, refere-se principalmente às causas e conseqüências da degradação ambiental; 2) Educação ao ar livre: incluem-se desde os antigos naturalistas até os escoteiros, montanhistas e outros grupos de esporte e cultura relacionados à natureza; 3) Gestão ambiental: tem raízes mais profundas na América Latina, é mais próxima da política, ligada aos movimentos por liberdades democráticas que reivindicam a participação popular na administração pública e definições do futuro; 4) Economia ecológica: esta bebe na fonte do "ecodesenvolvimento" de Sachs e de "O negócio é ser pequeno" de Schumacher, escritos nos anos 70 e mais tarde nos documentos "Nosso futuro comum" e "Nossa própria agenda".

Enquadrando-se num vasto leque de representações, destaca-se aqui a diversidade de concepções de educação ambiental que a relacionam a adjetivos como cidadania, política, conservação, popular, espiritual, enfim, significações que tentam aproximá-la, de formas diferenciadas, da problemática ambiental.

"A educação ambiental, entre outras coisas, é "uma ação, entre missionária e utópica, destinada a reformular comportamentos humanos e recriar valores perdidos ou jamais alcançados. Um esforço permanente na reflexão sobre o destino do homem" (Ab'Saber, 1993, p.15). 
Minnini e Pompéia (1995, p.171), colocam a educação ambiental como "um fator essencial para o desenvolvimento de uma racionalidade ambiental, que se funda numa ética ambiental renovada, e que caminha paralelamente à transformação das relações dos homens entre si, nos diversos grupos sociais e na organização do trabalho."

Para Reigota (1995, p.155-156), já é senso comum que "educação ambiental é uma educação política que visa à cidadania, num exercício permanente na busca e prática de uma educação que contribua na construção de possibilidades dialógicas de alternativas sociais e ecológicas"

Segundo Antuniassi (1995, p.44), educação ambiental constitui-se de "ações conscientizadoras num processo de vinculação do homem à natureza, que a civilização moderna vem negando, podendo isto inviabilizar sua própria sobrevivência."

Talvez esta grande diversidade de concepções possa nos orientar à necessidade de estudos epistemológicos da educação ambiental. Neste sentido, alguns autores vêm discutindo e desenvolvendo idéias na intenção de trazer melhor compreensão para o tema.

Como apontam Sansolo \& Manzochi (1995, p.171), "a diversidade da educação ambiental pode ser uma característica positiva, mas os resultados colhidos por diferentes pesquisadores demonstram a ausência de um processo com maior aprofundamento e sistematização sobre os seus fundamentos, objetivos, e metodologias de trabalho, não podendo isto ser ignorado pelos educadores e por aqueles que trabalham na sua formação."

Em alguns casos a epistemologia da educação ambiental é relacionada à questão ética, considerando-se a ausência desta como uma coisa preocupante, sendo até mesmo demonstrado claramente por alguns educadores uma dificuldade em reconhecer o papel da filosofia e epistemologia na educação e questão ambiental (Brugger,1994).

Preocupados com este assunto, Castro e Spazziani (2000, p.211) realizaram algumas reflexões, traçando alguns princípios norteadores com base 
em Piaget e Vygotsky, para possíveis aplicações na educação ambiental, visando a contribuição no avanço de sua construção teórica, enfatizando a necessidade de inserir em seu debate "uma praxis unificadora e pensar num fenômeno a partir de uma perspectiva epistemológica, psicológica, histórica e contextualizada".

Ciente desta necessidade e escassez de aprofundamentos teóricos dos "fazeres da educação ambiental" e apegando-se à diversidade destes "fazeres" destaca-se aqui um objetivo geral da educação ambiental "expressando talvez uma tendência de convergências entre as diferentes concepções: Contribuir para a conservação da biodiversidade, para a auto-realização individual e comunitária e para a autogestão política e econômica, através de processos educativos/participativos que promovam a melhoria do meio ambiente e da qualidade de vida" (Sorrentino, 1998, p.30).

A partir destes pressupostos, esta pesquisa fundamenta-se em alguns referenciais teóricos que buscam abranger as convicções desta pesquisadora e deste projeto.

Situando a educação ambiental a partir da premissa de que educação é a "mediação universal da existência histórica dos homens, sendo através dela que as novas gerações se introduzem no tríplice universo das práticas que viabilizam essa existência: a prática produtiva, representada pelo trabalho transformador da natureza física e criador de bens naturais de reposição da vida, prática social, representada pela participação na direção da vida política da sociedade e a prática simbolizadora, representada pela produção e fruição da cultura simbólica" (Severino citado por Sanzolo \& Manzochi, 1995, p.152).

Segundo Sansolo \& Manzochi (1995, p.152), "o exercício pleno destas três práticas, torna o educando um agente histórico da própria condição humana de existência em sociedade."

Acreditando ser a educação ambiental capacitada para este exercício, desde que a mesma seja dotada de necessários conteúdos e ações políticas, sociais e culturais, numa relação de internalização, buscando a tomada de 
consciência sobre as idéias que Morin (2000, p.28) declara ser "seres mentais que têm vida e poder."

Tomando as idéias do indivíduo e da sociedade como poder, pressupõese que o destino de nossa existência atrelado a esta posse deve ser submetido a processos educativos numa tentativa de utilizar a possessão de nossa mente sobre as idéias e destas sobre nossa mente "a fim de nos possuirmos justamente pelas idéias de crítica, de autocrítica, de abertura, de complexidade" (Morin, 2000, p.32).

Numa tentativa de assegurar que o poder destas "idéias" seja canalizado para uma criticidade capaz de mediação dos atos do sujeito e da sociedade em torno da melhoria da qualidade de vida e do ambiente, vê-se na educação ambiental, entrelaçada com cidadania, uma possibilidade desta realização.

De acordo com Osório citado por Avanzi (1998, p.27), "a educação para a cidadania deve ser entendida como uma pedagogia de construção de sujeitos, como uma teoria da transformação de si mesmo em ator, como uma teoria da subjetivação, da penetração do sujeito no indivíduo."

"Sendo o sujeito criado e fortalecido a partir da dissociação de seu dever social que o insere e o identifica no consumismo, deve a educação ambiental cidadã, responsável na formação deste sujeito, ultrapassar a visão funcionalista que prepara o indivíduo para aquilo que a sociedade impõe, buscando sua realização pessoal, além de ajudá-lo no reconhecimento de suas reais necessidades, chegando por fim à descoberta de capacidades e competências fortalecedoras da ação dos indivíduos na transformação e reorientação da sociedade" (Avanzi, 1998, p.28).

Neste sentido esta pesquisa, considerando o sujeito como o ator social dotado do poder de suas "idéias" capazes de uma transformação necessária nos rumos da sociedade, passa pela criação de espaços de participação. 
Numa construção de instrumentos que possam caracterizar o reconhecimento de direitos e representação de interesses, podem ser criados e utilizados os espaços públicos democráticos, "nos quais a pluralidade das opiniões se expressa, nos quais os conflitos ganham visibilidade e as diferenças se representam nas razões que constróem os critérios de validade e legitimidade dos interesses e aspirações defendidos como direitos" (Telles, 1994, p.101).

Visto desta forma, a educação ambiental referenciada nesta pesquisa vai de encontro à inclusão do sujeito em processos participativos que se utilizam deste e outros instrumentos de participação que proporcionem seu fortalecimento através de relações que promovam o diálogo.

Para Jacobi (1997), é necessário e desafiador aproximar o cidadão do processo decisório onde a participação, como forma de novas relações, é um componente essencial na formação de cidadãos como sujeitos sociais ativos.

Novamente a educação para cidadania como uma possibilidade de "motivar e sensibilizar as pessoas para transformarem as diversas formas de participação, em potenciais caminhos de dinamização da sociedade e de concretização de uma proposta de sociabilidade baseada na educação para a participação" (Jacobi, 1998, p.13).

Educar para participar criativa e criticamente como forma de reação aos poderes indesejados de decisão sobre nossas vidas, que costumeiramente caminham em direção contrária às nossas necessidades mais íntimas e também coletivas, quando nos ausentamos do poder esclarecido e crítico que podemos deter.

De acordo com Kelsen (1993, p.28), "se deve haver sociedade, e mais ainda, Estado, deve haver um regulamento obrigatório das relações dos homens entre si, deve haver um poder. Mas, se devemos ser comandados, queremos sê-lo por nós mesmos."

A ênfase desta pesquisa permeia as diferentes formas de participação e seus obstáculos, considerando-se que a participação ativa se dá pela 
necessidade de ser feliz e não por dever de cidadão, "participar para não ser governado, para viver em alegria de não ser comandado e para evitar que o desejo de não ser governado de uns, transforme-se em desejo de governar, e o poder se personalize" (Sawaia, 2001, p.125).

Um dos objetivos aqui pretendidos firma-se no propósito de fortalecimento do sujeito pelo estímulo da "potência de ação", sendo esta, a "capacidade de ser afetado pelo outro, num processo de possibilidades infinitas de criação e de entrelaçamento nos bons e maus encontros" (Sawaia, 2001, p.125).

Adota-se desta forma a subjetividade da participação, objetivando ir na "contracorrente do Zeigeist (espírito da época) para garantir que as necessidades humanas sejam priorizadas em lugar das econômicas e políticas, nas análises e planejamento da participação social” (Sawaia, 2001, p.123), considerando-se as "estruturas sociais habitadas pelo sujeito psíquico, que traduz as singularidades, as especificidades de cada um, o sujeito vivido e histórico" (Tassara \& Damergian, 1996, p.303).

\subsection{Agenda 21 local e educação ambiental}

Indicada como o mais importante resultado da Conferência das Nações Unidas sobre Meio Ambiente e Desenvolvimento, realizada no Rio de Janeiro em 1992, a Agenda 21 é apresentada em forma de um plano de ação estratégico para o desenvolvimento sustentável, assinado por mais de 150 países.

A Agenda 21, documento composto de 40 capítulos que está disposto em 4 seções, trata das dimensões sociais e econômicas, da conservação e gerenciamento dos recursos para o desenvolvimento, do fortalecimento dos principais grupos sociais e dos meios de implementação.

Alguns autores (Ferreira, Rodrigues) citados por Novaes (2001, p.140), em análise da Agenda 21, trazem para críticas o "seu tom consensual, onde os 
conflitos são camuflados em nome de um projeto comum, conciliador de tensões sociais, econômicas e geopolíticas."

Segundo Novaes (2001, p.142), apesar da ausência de algumas discussões mais críticas ao processo de desenvolvimento ser intrínseca à gênese da Agenda 21, dialeticamente, muitas de suas idéias são "reapropriadas por outras forças sociais, as quais se utilizam deste documento para a elaboração de estratégias críticas ao modelo de desenvolvimento".

Para Sachs (1993, p.64), mesmo com as críticas à Agenda 21 que a descreveram como um plano muito ambicioso, de caráter não obrigatório e com mínimas condições de obtenção de recursos para sua implementação a curto prazo, é necessário enfatizar sua importância como um "marco conceitual abrangente que visa estimular a imaginação social na elaboração de Agendas 21 em níveis local e nacional".

Reportando-se ao documento Agenda 21, capítulo 28, localizamos a Agenda 21 Local como uma recomendação que deveria ser iniciada logo após a Conferência, mas que tem encontrado inúmeras dificuldades para o êxito deste cumprimento. Conforme declara o documento :

“...Cada autoridade local deve iniciar um diálogo com seus cidadãos, organizações e empresas privadas e aprovar uma Agenda 21 Local..."

Uma pesquisa revelou que mais de 1800 cidades, em 64 países até 1996 envolveram-se em atividades de Agenda 21. No Brasil, embora hajam bons exemplos de processos de Agendas 21 locais em fase de construção e algumas já em conclusão, quantitativamente são bem pontuais (MMA, 2000).

Para Novaes (2001, p.155), se o levantamento quantitativo destas experiências no Brasil são imprecisos, o teor qualitativo então, mostra-se ainda mais incipiente, sendo que "os poucos relatos existentes, em sua maioria, carecem de análise crítica, e ainda com boa parte de materiais impressos de ordem institucional onde são enaltecidos as práticas e os gestores públicos envolvidos." 
Guimarães (1999, p.2), coloca-se de forma otimista quanto aos obstáculos e deficiências dos processos de elaboração da Agenda 21, afirmando que "nem tudo é desalentador, o importante é constatar que os exíguos exemplos mostram que é possível forjar o compromisso de amplos setores na construção de um futuro distinto."

Caracterizando-se como um potencial transformador, os processos de construção de Agendas 21 locais devem vincular-se ao seu fundamento político de sustentabilidade, que prende-se ao processo de fortalecimento da democracia e da construção da cidadania, buscando a inclusão verdadeira dos indivíduos no processo de desenvolvimento (Guimarães, 1999).

Desta forma, insere-se aqui a educação ambiental, voltando novamente ao documento Agenda 21, que no seu capítulo 36 traz a necessidade e recomendação de sua aplicação e desenvolvimento para todas as idades nos níveis formal e não-formal.

De acordo com Dias (1992) e Crespo (2000), a educação ambiental não se restringe apenas ao capítulo 36 , as referências à sua importância estão presentes em praticamente todo o documento.

Recomendada amplamente no documento Agenda 21 a partir de várias imbricações, a educação ambiental desempenha papel fundamental no processo de construção de Agendas 21 locais, com vistas a propiciar oportunidades de participação nas tomadas de decisão que definem os rumos da sociedade imbuída do sujeito social.

De acordo com Leff (1994, p.390), "desde as raízes da Terra com as bases da sociedade, surge a demanda popular de participar nas tomadas de decisões e na negociação direta de suas condições de existência", destacandose a educação ambiental como forma de estimular e criar espaços participativos para tal realização.

Diversas experiências de educação ambiental voltadas para a participação da população em torno da melhoria da qualidade de vida e 
sustentabilidade têm ocorrido através da elaboração de agendas 21 locais, como exemplos podem ser citados aquelas documentadas por Weid (1997).

Segundo Weid (1997, p.73), a Agenda 21 é o instrumento que orienta um plano estratégico de toda sociedade comprometida com a sustentabilidade, cabendo à educação ambiental neste processo "fortalecer o poder das populações, dando-Ihes instrumentos para planejar, gerenciar e implementar suas próprias alternativas às políticas sociais vigentes, além de resgatar e inventar soluções para melhoria das condições de vida e o desenvolvimento de relações mais solidárias e afetivas."

Conforme Crespo (2000, p.224), a educação ambiental recomendada pela Agenda 21 tem um papel crucial, que deve englobar "valores como cooperação; solidariedade; parceria; igualdade de direitos; fortalecimento dos grupos socialmente vulneráveis; democracia e participação e sustentabilidade como uma ética."

Um processo de construção de Agenda 21 local, deve representar a oportunidade de combinação dos "ideais de ética, justiça, participação, democracia e satisfação das necessidades" (Guimarães, 1999, p.3).

Combinar e garantir, de fato, este agrupamento de ideais durante o processo de construção de uma Agenda 21 local, acredita-se ser razoavelmente fácil e possível, dependendo principalmente do ponto de partida desta construção, que pode ser da sociedade civil ou do poder público. Difícil mesmo é garantir esta mesma combinação após o processo, ou seja, no momento da implementação da Agenda.

Esta preocupação surge devido ao próprio transcorrer desta pesquisa que se confronta constantemente com os diversos "poderes" que representam o poder público, sem o qual torna-se inviável processos de construção e implementação de Agendas 21.

De acordo com Novaes (2001, p.167), "não é raro assistirmos a agentes públicos fomentarem processos participativos - quer seja por modismo, demagogia, ou até por falta de clareza política - e no decorrer das discussões, 
perderem a condução política do processo, frente às demandas da sociedade civil organizada, caracterizando-se num mero exercício de demagogia, o que representa pouco ou nenhum avanço em termos de inovação em políticas públicas".

\section{6 poder público e os outros poderes}

A Constituição Federal de 1988, de forma avançada, traz capítulo inédito de meio ambiente, apontando a responsabilidade e dever do poder público e coletividade para garantia dos direitos de todos a uma vida saudável.

"O cumprimento dos princípios contidos na Constituição Federal, depende da ação conjunta e harmônica do Poder Público Federal, Estadual e Municipal" (Ferreira, 1997 p.27), "confirmando-se que estes ocupam lugar central no sucesso do enfrentamento das questões ambientais" (Amaral, 1995, p.99).

"É o Poder Público que deve dar o exemplo, demonstrando sua efetiva preocupação com a preservação do meio ambiente, devendo ainda estar convicto de que não se trata apenas de cumprir uma formalidade ou justificativa, e sim do cumprimento de um preceito constitucional" (Junqueira et al, 1995, p.110-113).

Intenciona-se aqui, destacar o poder do Poder Público representado em diversas esferas do governo, que interferem diretamente em nossas vidas, passando pela ampla questão ambiental.

Estes governos, criados a partir de regras, de leis, objetivam oferecer "a convivência harmoniosa, eliminando o risco da guerra de todos contra todos, sem a necessidade de um governante superior com poderes absolutos" (Dallari, 2001, p.94).

As constatações têm sido, visíveis e cientificamente, contrárias à desejada convivência harmoniosa, sendo encontrados como produtos de tais regras, "um governo sempre relacionado a um jogo de forças, ajudando a 
compor o quadro das desigualdades que caracterizam a sociedade" (Caldeira, 1981, p.213).

"A liberdade e a igualdade são dois valores fundamentais de todos os seres humanos e não apenas de alguns. Igualdade em seu sentido essencial, ou seja, todos os seres humanos valem a mesma coisa, e quando só alguns fixam as regras que os outros têm de obedecer há injustiça e desigualdade" (Dallari, 2001, p.90-97).

Segundo Dallari (2001, p.95), em nossa realidade "regras legais existem, mas são ignoradas e, em seu lugar, o governo põe medidas provisórias, fingindo que são leis, estabelecendo sozinho regras sobre o comportamento, os direitos e as obrigações do povo brasileiro."

Desta forma, continuamos no mesmo fazer histórico, onde o "processo de dominação se constrói pela imposição dessas regras de convívio definidas por grupos minoritários que detêm o poder político, ou poder econômico, ou o poder cultural" (Tassara, 2001, p.213).

Estes poderes exercidos pelo Poder Público podem ser encontrados nas relações múltiplas estabelecidas pelo povo e em nome dele, caracterizando-se talvez em complexos poderes de opressão e prazer.

Como explica Foucault (1999, p.154), "não podemos falar de um poder, mas sim descrever as relações de poder, o que é uma tarefa longa e difícil, portanto não podemos resumir tudo numa frase: o poder oprime. O poder dá prazer, pelo menos para algumas pessoas, temos toda uma erótica do poder, provando isto, que ele não é apenas opressivo."

Prazeroso para poucos e opressivo para muitos, o fato é que o poder ou as relações de poder, provocam polarizações resultantes do exercício e estabelecimento deste poder na sociedade. 
Tassara e Damergian (1996, p.303), dizem que:

"o homem traz como modelo em sua vida mental um vínculo de poder e vai repeti-lo na vida social, procurando estabelecer uma relação dominador - dominado, já inscrita em seu consciente. Estabelece este vínculo na vida social também, quando na busca de satisfação de seus desejos, constrói relações de amor e ódio, de gratificações e frustrações e outras através das quais sua identidade se constitui."

$\mathrm{Na}$ constituição da identidade do Poder Público, também aparece a mesma relação dominador - dominado, onde apenas "uma camada de privilegiados, decide o que é legal, o que é justo e o que é conveniente para a sociedade, provocando desta forma, uma série de injustiças e desigualdades, mas tudo feito dentro da lei" (Dallari, 2001, p. 106-107).

"A bem da verdade, não se pode pensar o poder sem fazer referência à desigualdade básica existente na sociedade, é apenas com referência à oposição ricos-pobres, que se pode entender o mau uso do poder, ou seja, o fato de os governantes não fazerem o que poderiam ou deveriam fazer" (Caldeira, 1981, p. 212).

É neste caminho que temos vivido toda nossa história, ininterruptamente construindo-se, e sempre em torno destas chaves opostas, determinantes do atendimento aos nossos desejos, necessidades e qualidade de vida, sendo a prioridade deste atendimento somente uma minoria.

Neste sentido, destaco a questão levantada por Tassara e Damergian (1996, p.304):

"Como a democracia pode ser o governo da maioria, quando por detrás dessa maioria existem os grupos de interesses, a minorias-elite, que 
impõem e manipulam esse querer, a verdade, a realidade e tudo o mais que a tele-tela tão competentemente trata de propagar?"

Demo (2001, p. 169-170), também fala de manipulações feitas por uma minoria dotada de poder na sociedade, ficando o "pobre - como sempre - de fora, sendo sobretudo massa de manobra."

É possível que, em meio às inúmeras relações de poderes estabelecidas e vivenciadas pelo Poder Público, encontremos saídas para alcançar aquela desejada convivência harmoniosa, objetivo, das regras sociais/jurídicas comentadas no início deste texto.

Como uma possibilidade de caminho a seguir, existe a oposição ao poder do Poder Público, ou seja, o poder do povo, que conforme Demo (2001, p.171), "acredita em tantas coisas como, nas cestas básicas, na renda mínima, nas assistências da primeira dama, porque não consegue acreditar no poder que tem, sobretudo se consciente e politicamente organizado."

O poder, seja do povo ou do Poder Público, "associa-se diretamente ao conhecimento, sendo sua dissociação um mito, que tem dominado e insiste em dominar o Ocidente. Assim temos o conhecimento submetido, na sua origem, ao poder político" (Tassara, 1995, p.42).

Foucault (1999, p.23), em análise do poder diz: "é somente nas relações de luta e de poder _ em como as coisas entre si, os homens entre si se odeiam, lutam, procuram dominar uns aos outros, querem exercer, uns sobre os outros, relações de poder_que compreendemos em que consiste o conhecimento."

Este mesmo autor, (1999, p.121), falando-nos das várias características do poder, menciona "um poder que atravessa e anima todos os outros poderes, é o poder epistemológico, poder de extrair dos indivíduos um saber, extraído dos próprios indivíduos, a partir do seu próprio comportamento."

Correlaciono às análises de Foucault um exemplo concreto deste poder, Chico Mendes, inserindo-se aqui em diversas passagens por Porto Gonçalves (2001, p.154-155), através das seguintes afirmações: 
"A inteligência de Chico Mendes soube perceber o feixe de relações que articulava o local ao regional, ao nacional e ao internacional.

Chico Mendes conseguiu educar uma boa parcela de ambientalistas, inclusive do primeiro mundo, colocando uma perspectiva própria, original, para a problemática ambiental.

Ele surpreende ao debater a biodiversidade dando-Ihes cores vivas quando nos fala da bacaba, do patauá, do buriti..."

Porto Gonçalves (2001, p.157), diz dos seringueiros: "só sabendo ler, escrever e contar poderiam gerir as suas cooperativas e se libertar do barracão do patrão, locus da exploração a que se viam submetidos", assim, educação era vista e assumida como algo de grande importância na vida deles.

Compreendendo a educação como uma das responsáveis por informações, saberes e conhecimentos, citarei Demo (2001, p.172): "Não é que educação tenha efeito automático, mas é uma das condições mais decisivas da constituição do sujeito capaz de história própria."

Aliando educação a participação poderíamos sonhar com o poder do povo sendo exercido de forma positiva a emancipação dos sujeitos.

"Sem a participação do povo, o governo da sociedade ficará nas mãos dos mais fortes, dos mais desonestos. É necessário um preparo para esta participação, que envolva o fundamental interesse e procura por melhorar os conhecimentos, obter mais informações junto com diversas reflexões" (Dallari, 2001, p.98).

"Conveniente ou não, o fato é que a influência do povo, nos rumos do Estado e do governo, dependerá, em boa parte, de sua própria maturação política, o que implica uma relação de equivalência com o grau de sua cultura" (Santana, 1995, p.82). 
Considerando isto como pressuposto:

"É necessário que a experiência brasileira, derivada de um passado de multiculturalismo, não tenha sido um sofrimento em vão por parte daqueles que tiveram de absorver a cultura que se expandia, obrigados a aprender a falar uma língua com sangue e dor para serem considerados latinos. Ao contrário, que ela contribua para promover a abertura do universo humano, para a imperiosa necessidade de construção de uma utopia pacifista e humanista que seja capaz de transcender à anunciada morte do sujeito" (Tassara e Damergian, 1996, p.307).

Talvez possamos considerar que neste sentido, mesmo que lentamente, temos caminhado, pois conforme Dallari (2001, p.110), "através do avanço significativo expresso no artigo $1^{\circ}$ da Constituição, em que diz: "Todo poder vem do povo e será exercido ou através de seus representantes ou diretamente por ele", significa um sinal de um novo tempo, é a expressão de uma nova cultura." 


\subsection{Objetivos}

\subsubsection{Objetivo geral}

Contribuir para a produção de conhecimentos comprometidos com a melhoria da qualidade de vida e conservação dos recursos naturais, históricos e culturais, através de uma pesquisa/intervenção educativa na Serra do Itapety.

\subsubsection{Objetivos específicos}

- Contribuir para a produção participativa de conhecimentos sobre a realidade da Serra do Itapety a partir de uma intervenção educacional;

- Propiciar aos moradores da Serra do Itapety, acesso facilitado de informações contextualizadas sobre a realidade local;

- Estimular entre os participantes desta pesquisa/intervenção reflexões que propiciem a "potência de ação" nos indivíduos e no grupo;

- Estimular e apoiar segmentos da sociedade civil e do poder público, a elaborarem uma Agenda 21 da Serra do Itapety, que contribua para o delineamento de ações conjuntas favoráveis ao meio ambiente e à qualidade de vida. 


\section{METODOLOGIA}

\subsection{Metodologia Qualitativa e Intervenção Social}

A realização desta pesquisa/intervenção construiu-se com o referencial teórico da metodologia qualitativa.

"A relevância da dimensão qualitativa faz parte, hoje, do patrimônio metodológico, mesmo que a ciência usual sinta, freqüentemente, dificuldades de a manejar" (Demo, 1994, p.37).

Segundo Ludke \& André (1986, p.11), "a pesquisa qualitativa tem o ambiente natural como sua fonte direta de dados e o pesquisador como seu principal instrumento, ela supõe o contato direto e prolongado do pesquisador com o ambiente e a situação que está sendo investigada".

Utilizar a pesquisa qualitativa buscando formas de conhecer e entender a realidade com identificação de seus problemas e possíveis soluções, é a contribuição conferida a esta metodologia (Patton, 1980).

Neste sentido a presente pesquisa apoiou-se na intervenção social para construir meios de inserir-se direta e prolongadamente na complexa situação considerada problema, visando a uma modificação da realidade apresentada. Esperava-se que, através de técnicas e estratégias, houvesse o autoreconhecimento no transparecer dos problemas e propostas de soluções. 
Tassara (1996, p.56) considera que intervenções sociais "condicionamse pelas delimitações de análises dos problemas que sustentam suas formulações, aspirando também à produção de um conhecimento novo, derivado da interação entre análise de problemas sociais, estratégias para enfrentá-los, suas aplicações e acompanhamentos de desempenho. Elas podem envolver estratégias participativas em diferentes graus e delineamentos de pesquisa-ação, com maior ou menor abrangência de campo de ação e/ou universo de análise".

Thiollent (1986, p.15) diz que "uma pesquisa pode ser qualificada de pesquisa ação quando houver realmente uma ação por parte das pessoas ou grupos implicados no problema sob observação". Este autor ainda chama a atenção para o fato deste tipo de pesquisa não deixar de ser uma forma de experimentação em situação real, na qual os pesquisadores intervêm conscientemente.

De acordo com Borda (1981, p.47), "ser cientista hoje significa estar compromissado com alguma coisa que afeta o presente e o futuro da humanidade. Portanto, a substância da ciência é tanto qualitativa quanto cultural; não é apenas uma mera quantificação estatística, mas a compreensão de realidades".

Para isto, atividades práticas foram realizadas na intenção de questionar e ao mesmo tempo produzir conhecimentos necessários para um melhor entendimento da situação estudada que resultassem em sua passagem de afetada para desejada.

"A prática tem lugar próprio, embora sempre dialeticamente imbricado na teoria, correspondendo sobretudo ao intento inovador da ciência, que pretende não esgotar-se na compreensão da realidade, mas transformá-la" (Demo, 1994, p.38).

Assumiu-se aqui um compromisso trilhado até hoje com as necessidades do presente que possam garantir a qualidade do futuro, a partir de realidades diagnosticadas antes e durante esta pesquisa. 
Conforme Viezzer e Ovalles (1994, p.53), a pesquisa participante utilizase de métodos que "geram na comunidade afetada um processo de autodiagnóstico, a fim de que os seus membros não só fiquem conscientes do problema, mas conheçam as causas responsáveis e procurem soluções."

Adotou-se como estratégia de planejamento da pesquisa intervenção educacional o incrementalismo articulado.

Segundo Costa (1986, p.369), o incrementalismo articulado tem como base, entre outros, o seguinte ponto:

"nenhum sistema social pode ser transformado de uma vez, partindo de estado inicial e chegando a um estado desejado. A transformação tem de ser gradual e cada mudança real que ocorre no sistema pode modificar a definição do estado desejado"

Este autor ainda coloca que esta estratégia procura criar condições para que um sistema aprenda a planejar interativamente conforme atitudes que incluam participação, coordenação, integração e continuidade.

Havendo desta forma uma conciliação e entrelaçamento de pontos na metodologia qualitativa, pesquisa ação, intervenção social e incrementalismo articulado, a presente pesquisa foi planejada, teorizada, praticada e construída e reconstruindo-se à medida que se fazia necessário nos encontros e confrontos com os participantes da pesquisa e comigo mesma.

\subsection{Materiais e Métodos}

Esta pesquisa - intervenção utilizou-se de uma fase exploratória para determinação dos atores e grupos sociais que deveriam e poderiam ser envolvidos na construção da Agenda 21 Local da Serra do Itapety.

"A fase exploratória consiste em descobrir o campo de pesquisa, os interessados e suas expectativas" (Thiollent, 1986, p.48).

Esta fase teve como base, principalmente minha experiência e vivência de 10 anos no local, como aluna universitária, estagiária e pesquisadora, que 
resultam em uma série de observações, análises de documentos, contatos com pessoas ligadas ao local e intervenções educativas e políticas.

Para um diagnóstico mais bem elaborado, realizei uma pesquisa documental que propiciou maior fundamentação técnica/política neste caminho trilhado.

Consultei o Plano de Manejo do Parque Natural Municipal da Serra do Itapety, Lei Estadual de Ocupação e Uso do Solo 4529/85, Mapas, Plano Diretor do Município de Mogi das Cruzes, arquivos de jornais locais e outros.

Esta consulta aconteceu em várias fases desta pesquisa, servindo de apoio para a definição das técnicas e melhor preparo na orientação e condução das atividades com os vários grupos sociais envolvidos aqui.

Desta forma elencaram - se grupos de interesse direto e indireto na Serra do Itapety, com identificação de divergências e convergências de ações e idéias.

Para cada grupo utilizei uma ou mais técnicas e/ou estratégias para um envolvimento que possibilitasse uma contribuição inicial para a construção da Agenda 21 Local da Serra do Itapety, através da identificação de suas expectativas, aspirações, sonhos, problemas e sugestões de soluções para a Serra do Itapety.

Para melhor acompanhamento dos fatos, apresento quadro cronológico dos grupos envolvidos e respectivas estratégias utilizadas. 


\begin{tabular}{|c|c|c|}
\hline Grupo & $\begin{array}{l}\text { Estratégias de } \\
\text { envolvimento }\end{array}$ & Período de realização \\
\hline $\begin{array}{l}\text { 1) Técnicos } \\
\text { (profissionais de } \\
\text { diversas áreas do poder } \\
\text { público e sociedade } \\
\text { civil) }\end{array}$ & $\begin{array}{l}\text { Reuniões, Encontro } \\
\text { Técnico Ambiental } \\
\text { (mesa redonda) e } \\
\text { entrevistas }\end{array}$ & $\begin{array}{l}\text { Julho de } 2000 \text { a agosto } \\
\text { de } 2001\end{array}$ \\
\hline $\begin{array}{l}\text { 2) Alunos das } \\
\text { Universidades Braz } \\
\text { Cubas e de Mogi das } \\
\text { Cruzes }\end{array}$ & $\begin{array}{l}\text { 1) Curso de Educação } \\
\text { Ambiental para } \\
\text { Sociedades } \\
\text { Sustentáveis e } \\
\text { Conservação da } \\
\text { Serra do Itapety } \\
\text { 2) Estágio } \\
\text { 3) Palestras - Oficinas }\end{array}$ & $\begin{array}{l}\text { 1) Setembro de } 2000 \text { a } \\
\text { fevereiro de } 2001 \\
\text { 2) Fevereiro a setembro } \\
\text { de } 2001 \\
\text { 3) Março a maio de } \\
2001\end{array}$ \\
\hline $\begin{array}{l}\text { 3) Moradores da Serra } \\
\text { do Itapety }\end{array}$ & $\begin{array}{l}\text { Questionários e } \\
\text { entrevistas }\end{array}$ & $\begin{array}{l}\text { Novembro de } 2000 \text { a } \\
\text { janeiro de } 2001\end{array}$ \\
\hline $\begin{array}{l}\text { 4) Professores dos } \\
\text { Ensinos Fundamental e } \\
\text { Médio }\end{array}$ & $\begin{array}{l}\text { 1) Curso de Educação } \\
\text { Ambiental e Agenda } 21 \\
\text { 2) Palestras - Oficinas }\end{array}$ & $\begin{array}{l}\text { 1) Abril de } 2001 \\
\text { 2) Maio e Junho de } \\
2001\end{array}$ \\
\hline $\begin{array}{l}\text { 5) Professores das } \\
\text { Universidades Braz } \\
\text { Cubas e de Mogi das } \\
\text { Cruzes }\end{array}$ & $\begin{array}{l}\text { Entrevistas semi- } \\
\text { estruturadas }\end{array}$ & Agosto de 2001 \\
\hline $\begin{array}{l}\text { 6) Vereadores da } \\
\text { Câmara Municipal de } \\
\text { Mogi das Cruzes }\end{array}$ & $\begin{array}{l}\text { Entrevistas semi- } \\
\text { estruturadas, reuniões e } \\
\text { observação participante }\end{array}$ & $\begin{array}{l}\text { Agosto a outubro de } \\
2001\end{array}$ \\
\hline
\end{tabular}

Quadro 1 - Cronologia dos grupos envolvidos na pesquisa. 


\subsubsection{Técnicos}

Este grupo foi composto por pessoas da sociedade civil e do poder público, representando a Prefeitura Municipal de Mogi das Cruzes, órgãos da Secretaria Estadual de Meio Ambiente do Estado de São Paulo, Ministério Público do Estado de São Paulo, Polícia Florestal e de Mananciais, Indústrias, Universidades, Cemasi, ONG's, Empresas de Assessoria Ambiental, Associação de Engenheiros e Arquitetos de Mogi das Cruzes, e comunidade.

Resolvi denominá-los de "Técnicos" por serem profissionais de formação em Biologia, Ecologia, Arquitetura, Direito, Engenharias, História, Geografia, Turismo entre outros, e assim entendê-los como indivíduos dotados de conhecimentos científicos e técnicos básicos e necessários para compreensão da Serra do Itapety, desta forma contemplando também uma versão técnica na construção da Agenda 21 Local da Serra do Itapety.

Um fator relevante na escolha deste grupo foi o poder de decisão e ação que estes exercem sobre o local, cada um em sua área de atuação, mas todos com um alto grau de entrelaçamento.

Para o envolvimento dos técnicos nesta pesquisa, realizei várias reuniões, entrevistas e um encontro técnico ambiental (mesa redonda).

\subsubsection{As reuniões}

Algumas reuniões foram necessárias para uma prévia apresentação do projeto "Educação Ambiental na Serra do Itapety - Construindo uma Agenda 21 Local" e também para obtenção das primeiras reações e opiniões sobre o próprio projeto e sobre a Serra do Itapety.

Estas reuniões, agendadas informalmente, aconteceram separadamente com representantes do Cemasi, Prefeitura Municipal, Universidades, Ministério Público, Indústrias e ONG's, sendo possível a partir daí o estabelecimento de 
uma relação mais próxima, clara e favorável ao projeto mesmo que, em alguns casos, favorável apenas no papel mas não de fato.

Durante estas reuniões que aconteceram individualmente no local de trabalho da pessoa, eu utilizava apenas minha caderneta de campo para o registro da conversa em seus aspectos mais curiosos e interessantes aos meus olhos, ouvidos e percepções.

As reuniões iniciavam-se quase sempre com minha apresentação sobre o projeto de maneira informal, citando os objetivos principais e quem eram os atores e grupos a serem envolvidos.

Opiniões, decisões, informações e esclarecimentos iam aparecendo, muitos buscados e outros não esperados.

A duração da reunião variava de pessoa para pessoa, variando em torno de 30 minutos a 2 horas.

\subsubsection{O Encontro Técnico Ambiental}
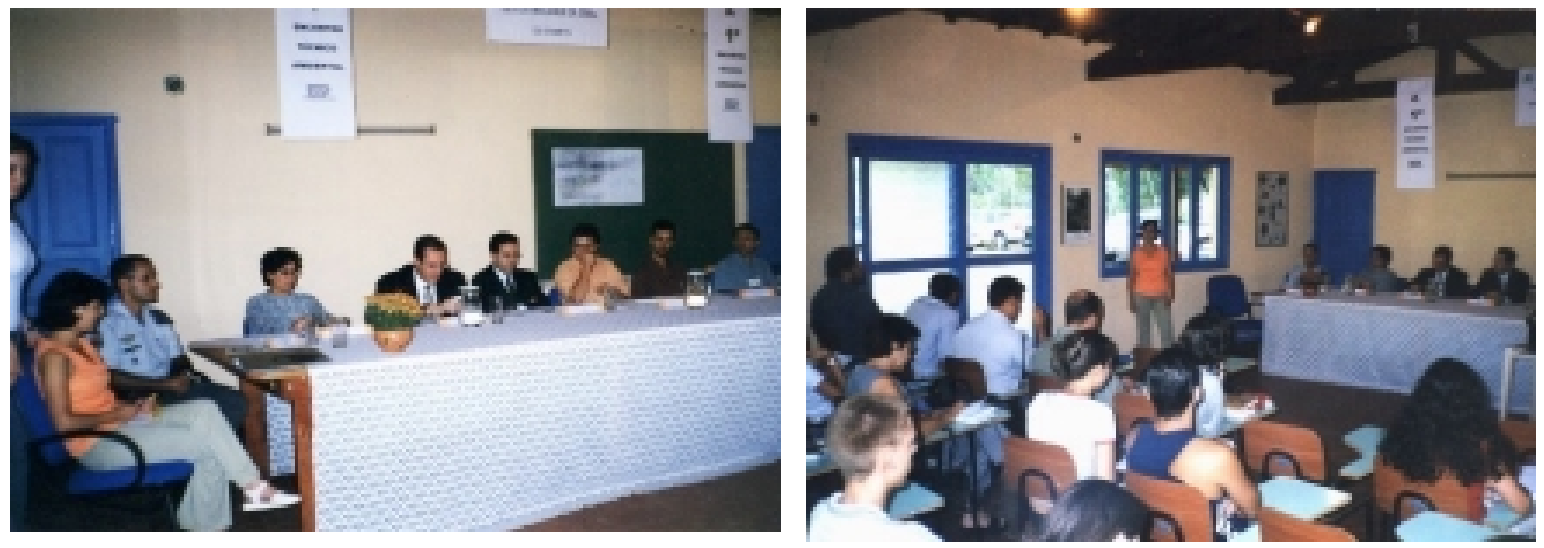

Figura 3 - Encontro Técnico Ambiental - mesa redonda.

Após as várias reuniões, decidi promover um "Encontro Técnico Ambiental" no dia 16/02/2001, onde os técnicos/autoridades pudessem tornar público, pelo menos parte, do que me relatavam nas reuniões fechadas que tivemos. 
Este Encontro foi estruturado em forma de mesa redonda, sendo por mim coordenado e moderado, utilizando em alguns momentos da técnica de visualização para facilitar a compreensão da linguagem e registrar o processo de modo mais dinâmico.

Os componentes da mesa foram:

- Promotor do Meio Ambiente

- Promotor da Ocupação e Uso do Solo

- Promotor da Cidadania

- Coordenador Técnico do CEMASI

- Secretário Municipal de Cultura e Meio Ambiente

- Diretor do Departamento Municipal do Meio Ambiente

- Tenente da Polícia Florestal e de Manancial

- Responsável Técnico do Departamento de Uso do Solo Metropolitano da SMA - SP

- Presidente da ONG - Bio Bras

O público, que totalizava 30 pessoas, foi composto por alunos universitários e representantes de indústrias, ONG's, Prefeitura Municipal de Mogi das Cruzes, Polícia Florestal, CEMASI, Universidades, empresas de assessoria ambiental, Associação de Engenheiros e Arquitetos e moradores.

Este evento objetivou prover esclarecimentos, socialização de informações, reflexões e o debate sobre os vários problemas e sugestões para soluções apontadas pelo grupo dos técnicos.

Para atender aos objetivos, o Encontro foi disposto com a seguinte programação: 
- 15 minutos para exposição do projeto "Educação Ambiental na Serra do Itapety - Construindo uma Agenda 21 Local" (por mim );

- 15 minutos para cada componente da mesa expor seus conhecimentos sobre a Serra do Itapety;

- 05 minutos para cada componente expor opinião sobre os problemas da Serra do Itapety e sugestões para solucioná-los.;

- 05 minutos para cada componente expor mensagem final com solução prioritária para os problemas da Serra do Itapety;

- 3 minutos para encerramento do evento, por mim realizado.

Este Encontro Técnico Ambiental, foi registrado através de anotações, registro oral (gravado), fotografias, filme e imprensa local (TV e jornal impresso), que fez a cobertura do evento e sua divulgação, além de entrevista posterior com esta pesquisadora para esclarecimentos da conclusão do acontecimento.

O evento foi restrito aos 20 convidados, que receberam um ofício/convite informando os objetivos e programação do Encontro, além de alguns alunos universitários participantes deste projeto convidados verbalmente.

\subsubsection{As entrevistas}

Buscando complementar, enriquecer e envolver outras pessoas na construção da Agenda 21 da Serra do Itapety, realizei entrevistas com aqueles que não puderam participar das reuniões e do Encontro Técnico Ambiental.

Foram 2 entrevistas: uma com o Secretário de Planejamento e Urbanismo e a outra com a Diretora do Departamento de Turismo, ambos da Prefeitura Municipal de Mogi das Cruzes.

As entrevistas semi - estruturadas foram registradas unicamente em minha caderneta de anotações. 


\subsubsection{Alunos da UBC e UMC}

A escolha deste grupo deu-se pela presença constante dos alunos universitários, (principalmente dos cursos de Biologia e Arquitetura), em pontos específicos da Serra do Itapety, com o propósito de realização de tarefas acadêmicas solicitadas por seus professores.

Além disto, visualizava-se a possibilidade de envolvimento destes alunos na etapa de entrevistas junto aos moradores.

Considerei também fundamental a inserção dos alunos universitários como grupo de interesse na Serra do Itapety, principalmente pela "necessidade de participar todos os níveis da estrutura educacional, introduzindo a dimensão de cidadania, para que o indivíduo informado, participe de forma ativa na definição dos rumos da sociedade" (Hogan,1990, p.151). ${ }^{1}$

Este grupo foi envolvido por esta pesquisa/intervenção através de um curso, de algumas palestras - oficinas e um estágio.

\subsubsection{O curso}

O curso intitulado "Educação Ambiental para Sociedades Sustentáveis e Conservação da Serra do Itapety" teve 82 horas/aulas, realizadas no período de setembro de 2000 a fevereiro de 2001, através de uma parceria entre a ESALQ/USP e o CEMASI.

O objetivo geral deste curso era capacitar alunos universitários para o exercício da educação ambiental em processos participativos de gestão de recursos naturais.

Os objetivos específicos eram:

\footnotetext{
${ }^{1}$ Publicação em anais do IV Seminário Nacional sobre Universidade e Meio Ambiente, Santa Catarina, 1990.
} 
- socializar e trabalhar conceitos e informações das áreas de conhecimento relacionadas à questão sócio-ambiental;

- integrar teoria e prática através de aprofundamento reflexivo, construção e produção de conhecimento;

- elaborar diagnóstico sócioambiental participativo junto aos moradores da Serra do Itapety;

- criar um grupo ativo de interesse na conservação da Serra do Itapety.

Para tanto, foram desenvolvidos por esta pesquisadora e convidados do Cemasi, USP, Butantan, UNICAMP e Ministério Público do Estado de São Paulo, os seguintes temas: Educação Ambiental, Biodiversidade, Unidades de Conservação, Plano de Manejo do Parque Natural Municipal da Serra do Itapety, História, Fauna e Flora da Serra do Itapety, Programas de Uso Público, Legislação Ambiental, Diagnóstico Rápido Participativo, Educação Ambiental e Metodologia Científica, Agenda 21 e por fim, Intervenção Social e Conhecimento Científico.

Com mais de 40 alunos inscritos, 20 foram selecionados, sendo 10 alunos de cada universidade mogiana, dos cursos de Biologia, Turismo, História e Ciências Aeronáuticas.

\subsubsection{O estágio}

Após o término do curso, 07 alunos foram selecionados para um estágio também em Educação Ambiental para Sociedades Sustentáveis e Conservação da Serra do Itapety.

O estágio com 260 horas, teve o objetivo de proporcionar aos alunos a vivência prática na continuidade da elaboração participativa do diagnóstico junto aos moradores da Serra do Itapety, além do acompanhamento detalhado de 
várias etapas que envolveram os outros grupos para a construção da Agenda 21 Local da Serra do Itapety.

\subsubsection{As palestras-oficinas}
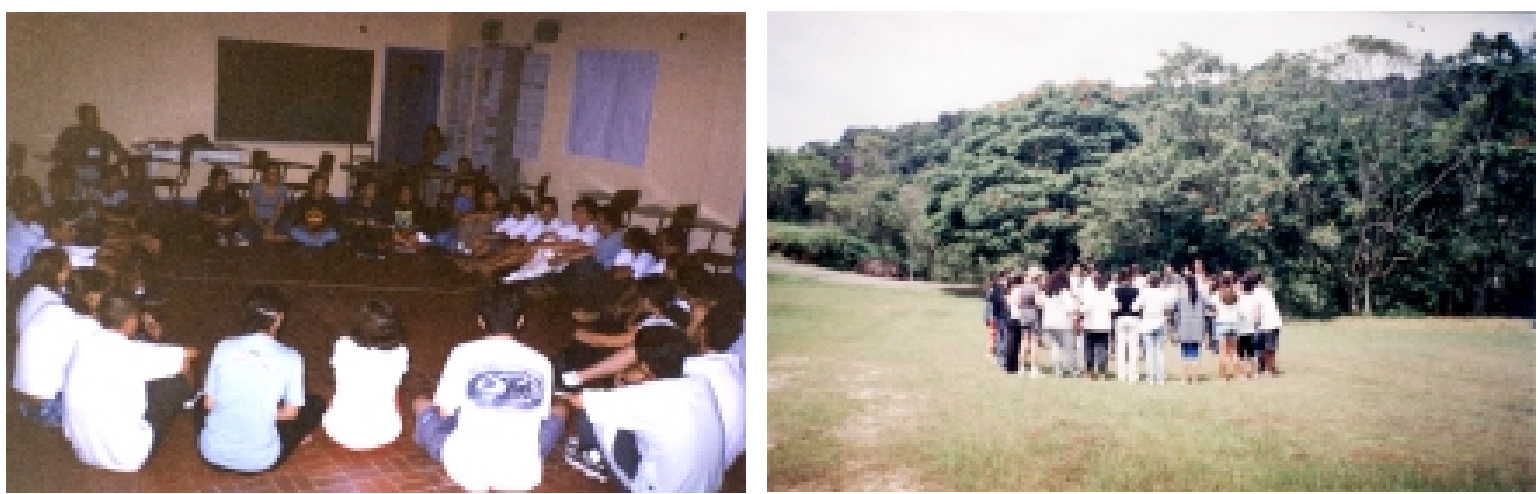

Figura 4 - Dinâmicas de grupo com alunos universitários.

A fim de ampliar o número de alunos informados sobre a presente pesquisa para construção da Agenda 21 Local da Serra do Itapety e também obter um número maior de opiniões sobre os problemas e sugestões de solução, realizei 03 palestras/oficinas com a participação total de aproximadamente 200 alunos dos cursos de Comunicação Social, Letras, Pedagogia, Arquitetura, Engenharia Ambiental, Psicologia, Turismo e Biologia.

Tanto o Curso quanto as Palestras/Oficinas realizadas com este grupo, iniciavam-se com uma dinâmica de visualização onde o aluno expunha suas opiniões sobre os problemas da Serra do Itapety e possíveis soluções, assim como seus sonhos e expectativas para ela. Expunham também algumas informações básicas que detinham sobre a realidade da Serra, apontando ainda algumas formas, deles em particular, que contribuiriam para o alcance da qualidade de vida e conservação dos recursos naturais existentes no local.

Esta dinâmica possibilitava uma breve avaliação destes participantes, permitindo um melhor direcionamento da palestra realizada logo em seguida.

Esta por sua vez, expunha os objetivos deste projeto, bem como, informações sucintas sobre o documento Agenda 21, experiências de 
elaboração de Agendas locais, correntes da educação ambiental e metodologias participativas.

A cada palestra - oficina que durava cerca de 3 horas, o número médio de participantes era de 60 alunos.

\subsubsection{Moradores}

Selecionei alguns locais residenciais da Serra do Itapety para realização de entrevistas através de questionário com os moradores, objetivando caracterizá-los, além de obter suas opiniões sobre os vários aspectos que envolvem a Serra.

Os locais foram selecionados a partir dos agrupamentos residenciais existentes na área delimitada como Serra do Itapety.

Nesta etapa da pesquisa contei com a participação dos alunos universitários que estavam no curso/estágio de "Educação Ambiental para Sociedade Sustentáveis e Conservação da Serra do Itapety". Num primeiro momento, houve a participação de todos estes alunos na realização das entrevistas, mas devido ao período de férias (janeiro/2001), apenas 07 deram continuidade finalizando esta fase.

Esta atividade funcionou como uma parte prática do curso, sendo elaborado em conjunto com estes alunos, o questionário a ser aplicado em forma de entrevista:

1) A residência é própria?

2) Quantas pessoas moram na casa?

3) Há quanto tempo mora neste lugar?

4) Porque escolheu a Serra do Itapety para morar?

5) Quando chegou aqui, como era o lugar?

6) Como gostaria que a Serra do Itapety estivesse hoje?

7) Quais problemas existentes na Serra do Itapety?

8) Tem alguma idéia/sugestão do que fazer para resolvê-los? 
9) O que a Serra do Itapety representa para você?

10) Tem algum sonho para este lugar?

$\mathrm{Na}$ análise dos resultados, as perguntas 1 e 2 foram desconsideradas nesta pesquisa.

Os alunos sob minha orientação e de alguns convidados, ministrantes do curso, foram preparados para a ida ao campo e contato direto com os moradores, através dos questionários.

Foram aplicados 213 questionários, num período de 2 meses, cada aplicação tinha duração variada entre 15 e 30 minutos, sendo algumas das conversas, registradas em fitas cassetes e/ou cadernetas de campo dos alunos.

Os questionários correspondem a 213 residências. Sempre com o cuidado de procurar alguém responsável pela casa. Entretanto, muitas vezes, outras pessoas colaboravam nas respostas, ocorrendo em alguns casos um bate papo que possibilitava uma diversidade maior de dados.

Os alunos atuavam em duplas, que se revezavam, apresentando-se sempre como universitários tendo por objetivo realizar pesquisa sobre a Serra do Itapety e seus moradores.

De forma geral, foram bem recebidos, mas de maneira desconfiada e cautelosa pelos moradores, que logo perguntavam se eram da Prefeitura.

A experiência vivida por estes alunos durante as entrevistas, incluindo seus resultados parciais, eram socializadas, discutidas e refletidas no curso com todo o grupo, a cada aula seguinte do campo.

A tabulação dos dados teve a participação apenas do alunos que continuaram no projeto através do estágio, realizando a primeira separação dos dados.

\subsubsection{Professores dos Ensinos Fundamental e Médio de Mogi das Cruzes}

Inúmeras razões me levaram a incluir este grupo no rol de interessados na Serra do Itapety e construção de sua Agenda 21 Local, entre elas, destaca- 
se a alta demanda das escolas públicas estaduais e municipais pelo programa de uso público existente no Parque Natural Municipal da Serra do Itapety.

O Parque Natural Municipal está aberto, para recepcionar através de visitas monitoradas, qualquer pessoa interessada sem discriminações, sendo que, o público da rede escolar de Mogi das Cruzes e região, representa $85 \%$ dos que procuram este trabalho.

Visto este grupo como um segmento da sociedade de fundamental importância, não só para a Serra do Itapety, mas também para todo o município de Mogi das Cruzes, através de suas ações de multiplicadores e formadores de opinião, não hesitei em promover uma intervenção que propiciasse um repertório conexo para atuação destes atores na construção da Agenda 21 Local da Serra do Itapety.

Para envolver estes professores, objetivando sua participação, foi realizado um curso e também palestras-oficinas, estas nos mesmos moldes, já descritos, realizadas com os alunos.

\subsubsection{O curso}

O curso recebeu o nome de "Educação Ambiental e Agenda 21" com 16 horas/aulas, realizado através de parceria entre ESALQ/USP e CEMASI.

Justifica-se ainda a realização deste curso, com base na Lei n 9.795 de 27 de abril de 1999, dispondo sobre a Educação Ambiental e a Política Nacional de Educação Ambiental, que traz em seu artigo 11, Parágrafo único a seguinte determinação:

"Os professores em atividade devem receber formação complementar em suas áreas de atuação, com o propósito de atender adequadamente ao cumprimento dos princípios e objetivos da Política Nacional de Educação Ambiental".

Os objetivos específicos deste curso eram: 
- prover informações necessárias para atualização, reflexão e ação;

- oferecer espaço prático e teórico para a construção de conhecimentos sobre educação ambiental e Agenda 21;

- estimular professores na participação e elaboração de projetos na escola buscando a melhoria da qualidade ambiental e de vida;

- produzir conhecimento sobre a Serra do Itapety;

- obter a contribuição dos professores para a construção da Agenda 21 Local da Serra do Itapety

Dezoito professores das disciplinas de Ciências, Biologia, Matemática, Geografia, História, Educação Física, Inglês e Português participaram do curso que abordou os seguintes temas desenvolvidos por esta pesquisadora: educação ambiental, áreas naturais protegidas, biodiversidade, Serra do Itapety - história, fauna e flora, participação e cidadania, Agenda 21, Agenda 21 e escolas.

\subsubsection{As palestras-oficinas}

Foram realizadas 2 palestras-oficinas para um total aproximado de 100 professores, visando a uma divulgação maior das informações sobre a Construção da Agenda 21 da Serra do Itapety, assim como obter um número maior de opiniões sobre os problemas e soluções para a Serra do Itapety.

As palestras-oficinas realizadas com os Professores dos Ensinos Fundamental e Médio, tiveram os mesmos objetivos e moldes já citados no grupo dos alunos.

Cada Palestra-Oficina, com duração em torno de 03 horas, tinha uma média de 50 professores. 


\subsubsection{Professores da UBC e UMC}

Os professores universitários foram chamados a participar deste projeto por acreditar ser importante as idéias de Luckesi (1990, p.42), que idealiza uma universidade onde seja "possível e habitual trabalhar a nossa realidade histórico - geográfica, desde a esfera mais próxima até as mais remotas, sendo a grande tarefa do corpo universitário, estar atento e estudar os desafios de nossa realidade."

Um outro fator decisivo na escolha deste grupo, foi a presença de alguns deles em pontos da Serra do Itapety, com interesses pedagógicos e de pesquisa

Através de entrevistas, os professores dos cursos de graduação em Biologia, Matemática, Pedagogia, Psicologia, Letras, Economia, Arquitetura e Engenharia Ambiental, contribuíram com suas opiniões e discussões para a construção da Agenda 21 Local da Serra do Itapety

\subsubsection{As entrevistas}

Dos 25 professores procurados, um se recusou a dar entrevista, mas os demais foram entrevistados nas próprias Universidades e tiveram seus depoimentos registrados em minha caderneta de anotações e nos apontamentos feitos por um estagiário que também anotava o que era possível.

A entrevista semi-estruturada seguia o roteiro abaixo:

- Você conhece a Serra do Itapety?

- Quais são os problemas da Serra do Itapety?

- Possui alguma sugestão para solução destes problemas?

- Qual o papel da Universidade quanto 'a Serra do Itapety?

- Conhece o trabalho das universidades? Qual sua visão sobre ele? 
- Tem algum sonho para a Serra do Itapety?

A entrevista, que durava em torno de 40 minutos, era iniciada com as devidas apresentações, minha, do estagiário e do projeto com um breve esclarecimento da Agenda 21 e público envolvido para a construção da Agenda da Serra do Itapety.

\subsubsection{Vereadores da Câmara Municipal de Mogi das Cruzes}

A opção em deixar os vereadores como um grupo do poder público à parte, deve-se ao histórico de complicações de seus atos e discursos ambientais e também pelo importante papel que os mesmos representam na tomada de atitudes e decisão dos conseqüentes rumos dos acontecimentos que podem ou não garantir a conservação da Serra e a melhoria da qualidade de vida na região.

De acordo com Kranz (1995, p.10), "apesar da iniciativa de estabelecer um processo de Agenda 21 muitas vezes se originar na comunidade, é fundamental obter apoio da Câmara dos Vereadores para o alcance dos resultados desejados."

Desta forma, buscou-se o envolvimento dos vereadores neste projeto, através de entrevistas, reuniões e observações.

\subsubsection{As entrevistas}

Esta técnica foi considerada a mais viável para o acesso aos vereadores, com uma abertura para a exposição sucinta do projeto, já em fase avançada de desenvolvimento e também para buscar suas opiniões sobre a Serra do Itapety.

Dos 21 vereadores, 13 foram entrevistados por mim, com a colaboração de uma estagiária que fazia todas as anotações possíveis. Os outros oito não foram encontrados (a não ser nos momentos de sessão), durante 1 mês de procura insistente. 
Houve uma receptividade muito grande por todos os vereadores entrevistados, sendo estas entrevistas realizadas em sua maioria em seus gabinetes na Câmara e apenas em 2 casos no escritório particular deles.

As entrevistas semi - estruturadas, variaram de 15 minutos a 1 hora, de acordo com a disponibilidade do vereador em falar mais ou menos sobre as questões propostas.

Iniciava a entrevista apresentando-me como aluna de mestrado da ESALQ/USP, que estava desenvolvendo o projeto "Educação Ambiental na Serra do Itapety - Construindo uma Agenda 21 Local" e Alecsandra Tassoni a estagiária do Projeto.

Fazia uma breve explicação do que tratava o referido projeto, informando que a opinião dele sobre a Serra era importante, pedindo em seguida sua permissão para anotarmos suas respostas.

Alguns vereadores começavam a discorrer sobre a Serra do Itapety sem deixar espaço para interrupções, apenas no final de suas falas eles davam aberturas para outras indagações de minha parte, enquanto outros pediam para que eu fizesse as perguntas desejadas e restringiam-se a respondê-las de forma bem resumida.

De qualquer forma eu seguia um roteiro básico para as entrevistas, abordando as seguintes questões:

1. Qual a representação que a Serra do Itapety possui para o senhor (a)?

2. Quais os principais problemas da Serra do Itapety?

3. Quais as possíveis soluções para estes problemas?

4. Como os vereadores podem contribuir para a qualidade de vida, ambiental e da Serra do Itapety?

5. O que os vereadores tem feito para contribuir?

6. Tem algum sonho para a Serra do Itapety? 
No final de cada entrevista, eu avisava que este era meu primeiro contato, pois necessitaria de um maior envolvimento dos mesmos, e para isto eu enviaria relatórios sobre o projeto e convite para reuniões.

\subsubsection{Observação Participante}

Esta técnica foi utilizada apenas de forma complementar para obtenção de maiores informações sobre as características de trabalho dos vereadores e melhor entendimento do funcionamento da Câmara Municipal, além de um reconhecimento das opiniões sobre a Serra do Itapety.

Durante 3 meses freqüentei a Câmara Municipal de Mogi das Cruzes no mínimo 3 vezes por semana, sendo que em dois destes dias, aconteciam as sessões do plenário, oportunidade rica para observar, nos vereadores e em seu conjunto, o discurso, as atuações (ações), o diálogo entre eles.

Nestas observações, registrei minha visão na caderneta de anotações,

além de buscar também algo mais concreto de que minhas observações, solicitando fita gravada na plenária e alguns documentos assinados pelos vereadores.

\subsubsection{As reuniões}

Após algumas entrevistas e observações, surgiram alguns resultados positivos com desdobramentos do projeto, possibilitando a minha participação em reuniões internas da Câmara Municipal.

Participei de 03 reuniões com duração de 3 horas cada, com a presença de 05 vereadores e seus assessores, sendo a primeira destas destinada a minha apresentação.

Nas outras duas reuniões foram ouvidos 2 secretários municipais Secretaria de Planejamento e Urbanismo e Secretaria de Cultura e Meio Ambiente - e também o Coordenador Técnico do Cemasi, quando foram 
indagados sobre a visão e posição dos mesmos quanto à Agenda 21, sendo citado o referido projeto como o exemplo.

Continuo participando destas reuniões na Câmara que acontecerão até aproximadamente dezembro de 2002, com objetivo de fomentar e subsidiar a construção da Agenda 21 Local de Mogi das Cruzes.

Estas reuniões foram utilizadas como uma técnica favorável à socialização de informações, reflexões, integração e participação dos vereadores e outros atores, na construção da Agenda 21 Local da Serra do Itapety.

\subsubsection{Todos os grupos}

Quero ressaltar que minha apresentação para todos os grupos foi sempre como aluna da ESALQ/USP, que estava desenvolvendo uma pesquisa de mestrado, visando à construção de uma Agenda 21 para a Serra do Itapety.

Devido aos meus vínculos institucionais de vários anos com a Serra do Itapety, muitos atores envolvidos nesta pesquisa dificilmente conseguiram fazer uma separação, o que em alguns momentos apresentou-se de forma positiva e em outros negativamente.

\subsubsection{Olhares sobre a Serra do Itapety}

Após a realização das atividades descritas no item anterior, sistematizei as respostas obtidas nas perguntas centrais para a elaboração da Agenda 21.

Estas perguntas, feitas a todos os grupos, referiam-se aos sonhos, problemas e soluções para os problemas na Serra do Itapety.

A sistematização consistiu em relacionar, de forma sintética, tudo que foi apontado pelos sujeitos da pesquisa. A partir disso foram feitos alguns agrupamentos, sem que perdessem o sentido original das respostas dadas. 
Primeiramente, foram sistematizados os sonhos, problemas e soluções de cada grupo, e num segundo momento, tudo foi unificado agrupando o que se repetia.

Assim obtive o que chamamos de "Olhares sobre a Serra do Itapety", com a versão de cada grupo e também a geral.

Com o resultado destes "Olhares", preparei um resumo do projeto, juntamente com a versão de cada grupo, entregando em mãos para cerca de 300 pessoas representantes destes grupos trabalhados.

Busquei com isto a divulgação da construção da Agenda 21 da Serra do Itapety, assim como, da diversidade de "olhares", para que cada grupo pudesse conhecer a versão do outro. Esperava também uma abertura para novos envolvimentos e participação neste processo.

Após 10 dias da entrega deste resumo, enviei ofício convidando representantes dos grupos envolvidos para uma ampla reunião geral.

\subsubsection{Reunião Geral}
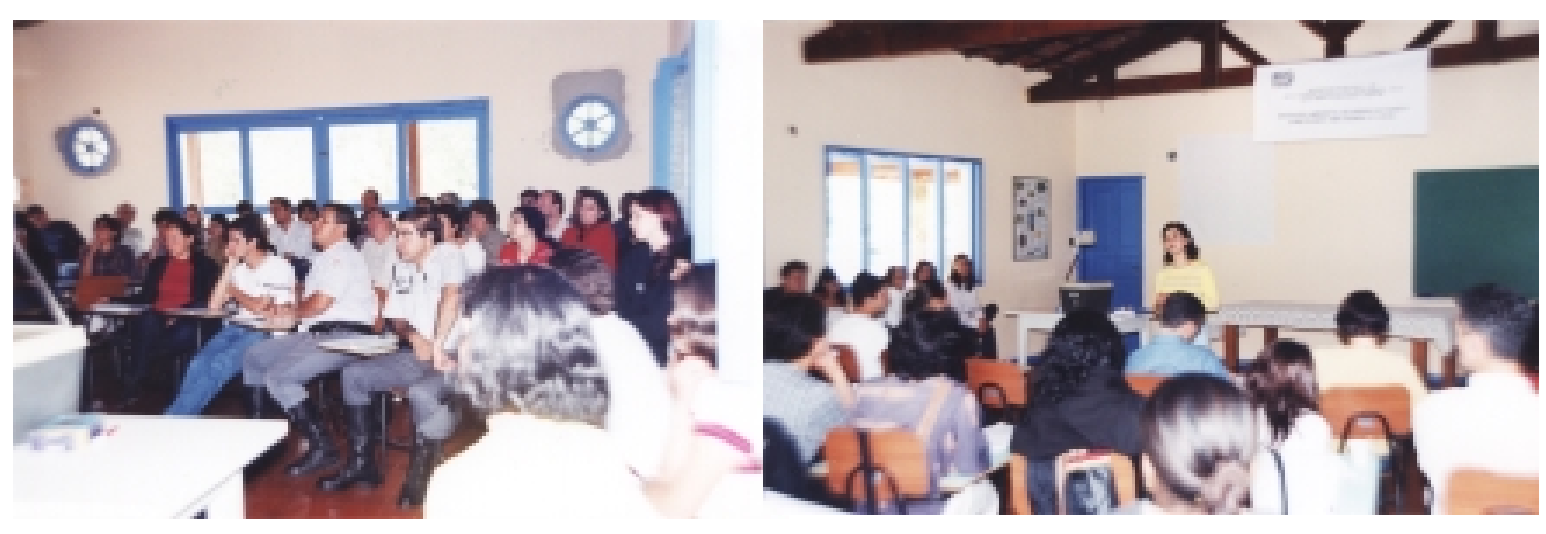

Figura 5 - Reunião geral com todos os grupos da pesquisa.

Esta reunião, ocorrida em 20/09/2001 no Parque Natural Municipal da Serra do Itapety, teve a participação de 58 pessoas representando cerca de 20 órgãos (instituições) do poder público e da sociedade civil. 
Ela teve o objetivo de confrontar os "olhares" diversificados sobre a Serra do Itapety, propiciando reflexões e debate sobre o assunto.

A reunião teve a seguinte programação:

- Abertura feita por mim com agradecimentos, objetivos da reunião, esclarecimentos sobre os "Olhares", e apresentação de proposta para criação de Comissão para sistematização da Agenda 21 da Serra do Itapety.

- Exposição do tema "Recursos Naturais da Serra do Itapety" por Pedro Tomasulo (professor universitário).

- Composição de mesa com 5 voluntários do público para auxílio desta pesquisadora na condução de debate sobre os problemas da Serra do Itapety e as sugestões para soluções, seguida da priorização destes.

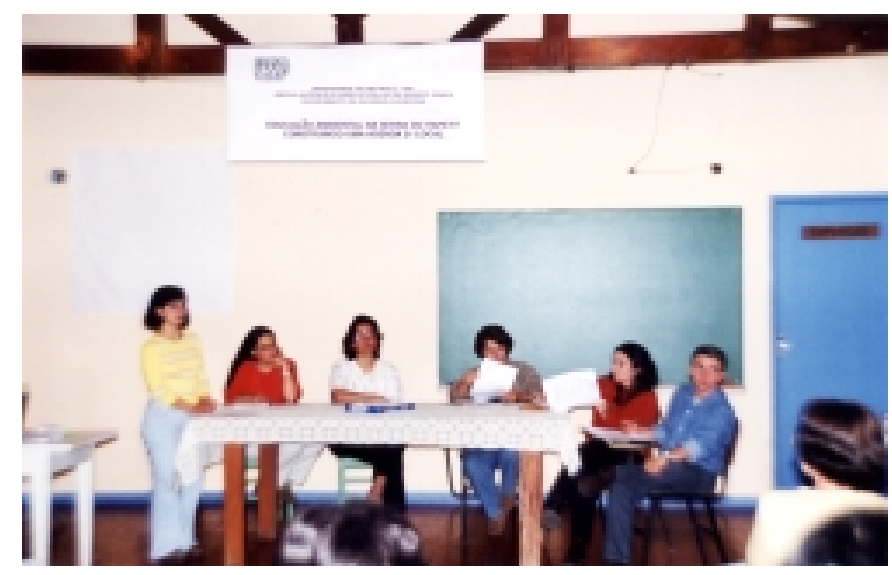

Figura 6 - Mesa composta para condução das discussões sobre os olhares da Serra do Itapety.

Nesta reunião, todos os presentes puderam opinar sobre cada item apresentado na versão geral dos "Olhares sobre a Serra do Itapety". 


\subsubsection{Comissão}

Para continuidade dos trabalhos com todos os grupos criou-se a Comissão da Agenda 21 da Serra do Itapety, composta por 17 pessoas representantes dos seis grupos envolvidos, apresentando-se abaixo:

- 2 vereadores

- 2 professoras dos Ensinos Fundamental e Médio

- 2 alunos universitários

- 2 moradores do entorno da Serra do Itapety

- 2 professores universitários

- 2 técnicos da Prefeitura Municipal

- 5 técnicos da sociedade civil (estou incluída aqui)

Esta foi a primeira composição da Comissão, que devido a mudanças no quadro de funcionários da Prefeitura Municipal e também pela procura de interessados em fazer parte desta, vem se modificando.

Provavelmente estas modificações ainda ocorrerão por motivos que explicarei nos resultados da mesma.

Esta Comissão dividida em coordenação, da qual faço parte junto com a vereadora Sonia Sampaio, e integrantes, tem os seguintes objetivos:

- discutir e avaliar os problemas e sugestões para soluções apresentadas pelos grupos desta pesquisa;

- sistematizar um Plano de Ação da Agenda 21 para a Serra do Itapety, a partir do relatório "Olhares sobre a Serra do Itapety";

- Promover ampla reunião/encontro para divulgação, discussão e análise da Agenda 21 da Serra do Itapety;

- Incorporar e sistematizar outras contribuições editando nova versão da Agenda 21 da Serra do Itapety; 
- Publicar a Agenda 21 da Serra do Itapety;

- Coordenar e monitorar a implantação da Agenda 21 da Serra do Itapety.

Seguindo estes objetivos, a Comissão a partir da data de sua formação tem desenvolvido suas atividades através de reuniões periódicas, considerando-se para efeito de análises desta pesquisa, apenas até a sua oitava reunião, ocorrida em fevereiro de 2002.

Estas reuniões têm ocorrido na Câmara Municipal de Mogi das Cruzes, pelo fato de oferecer comodidade no que diz respeito a aspectos como infraestrutura necessária e fácil localização.

A cada reunião, todos os integrantes da Comissão são chamados, com uma semana de antecedência, através de ofício da coordenação, incluindo a pauta, que normalmente já ficara definida na reunião anterior, com a anuência de todos os presentes.

Apresentarei no capítulo III os resultados das primeiras 08 reuniões que trabalharam, prioritariamente, a sistematização da Agenda 21 em forma de Plano de Ação.

Apresentei para a Comissão um modelo de Plano de Ação, que adaptei a partir da Agenda 21 do Pedaço (Ecoar, 1997) e do Construindo Nosso Futuro Guia do Cidadão (Prefeitura da Cidade do Rio de Janeiro, 1996). 


\begin{tabular}{|c|c|c|c|c|c|c|}
\hline Objetivos & Metas & Ações & Responsáveis & Prazo & Indicadores & Custos \\
\hline $\begin{array}{l}\text { Estes são } \\
\text { mais } \\
\text { concretos e } \\
\text { específicos } \\
\text { que as } \\
\text { aspirações e } \\
\text { os sonhos. }\end{array}$ & $\begin{array}{l}\text { Desdobramen } \\
\text { tos dos } \\
\text { objetivos. } \\
\text { Resultados } \\
\text { que podem } \\
\text { ser medidos e } \\
\text { têm prazo } \\
\text { para o } \\
\text { cumprimento }\end{array}$ & $\begin{array}{l}\text { O que } \\
\text { vamos } \\
\text { fazer para } \\
\text { alcançar as } \\
\text { metas e } \\
\text { objetivos. }\end{array}$ & $\begin{array}{l}\text { Cada ação } \\
\text { deve ter um } \\
\text { responsável ou } \\
\text { grupo de } \\
\text { responsáveis. }\end{array}$ & $\begin{array}{l}\text { Determinar } \\
\text { quando } \\
\text { iniciaremos } \\
\text { o planejado } \\
\text { e quando a } \\
\text { ação } \\
\text { estará } \\
\text { concluída. }\end{array}$ & $\begin{array}{l}\text { Medidas que } \\
\text { informam } \\
\text { sobre a } \\
\text { eficácia da } \\
\text { ação. As } \\
\text { informações } \\
\text { que } \\
\text { sinalizarão } \\
\text { se as ações } \\
\text { estão } \\
\text { provocando } \\
\text { os } \\
\text { resultados } \\
\text { esperados. }\end{array}$ & $\begin{array}{l}\text { Incluir tudo } \\
\text { que for } \\
\text { necessário } \\
\text { para } \\
\text { realização } \\
\text { da ação. } \\
\text { Quais os } \\
\text { recursos } \\
\text { financeiros } \\
\text { necessários. }\end{array}$ \\
\hline
\end{tabular}

Quadro 2 - Modelo de plano de ação adotado pela Comissão da Agenda 21 da Serra do Itapety.

Com este modelo, discutido e aceito pela Comissão, iniciamos o processo de sistematização do Plano de Ação a partir dos "Olhares sobre a Serra do Itapety".

Este processo vem ocorrendo através da discussão, reflexão e consenso, dos presentes às reuniões, de item por item dos "Olhares", encaixando cada um dentro de um tópico do Plano de Ação.

Desta forma, temos discutido os problemas e transformado os sonhos e as sugestões para soluções em objetivos, metas, ações, responsáveis, prazo e indicadores.

Quando encontramos um destes tópicos do Plano de Ação sem correspondente nos "Olhares", então discutimos, criamos e inserimos no documento novos complementos. 
Esta Comissão tem uma previsão para encerrar esta fase de sistematização até o mês de março, para então partir ao terceiro objetivo, ou seja, promover amplo encontro que propicie a divulgação desta etapa do trabalho, seguido de discussões, reflexões e novas contribuições.

A conclusão da Agenda 21 da Serra do Itapety, está estimada para junho de 2002. 


\section{RESULTADOS E DISCUSSÕES}

Apresento primeiramente os resultados e discussões de cada grupo nesta pesquisa, tentando evidenciar em cada um, suas características, as formas e motivos de participação ou ausência desta, nas técnicas/estratégias desenvolvidas.

\subsection{Técnicos}

Interessante este grupo. Bem diversificado, dos autoritários e impositivos, aos amáveis, gentis e dispostos. Alguns empolgados com a temática e seus trabalhos, outros ausentes e sem motivação com o próprio trabalho.

O seu conjunto poderia representar o que há de melhor, pelo seu poder de conhecimento, de ação e também político. Isto representa o meu olhar sobre este grupo.

Chegar a estes "técnicos" foi fácil pela acessibilidade deles. Exigiu apenas uma certa dedicação em conversar com quase todos separadamente, o que foi muito prazeroso e enriquecedor. Busquei, a princípio, informá-los sobre a existência do projeto e saber se havia algum interesse deles em participar do mesmo e de que forma isto poderia ocorrer.

Os primeiros contatos, alguns por telefone e outros pessoalmente, resultaram nas seguintes reações:

"Ótimo! Conte conosco, estaremos participando em tudo que for preciso." (Promotores de Justiça do Ministério Público - pessoalmente). 
"Olha, eu não posso ajudar em nada, aqui não tem ninguém preparado, que saiba sobre a Serra do Itapety, é melhor procurar alguém em São Paulo."

(Técnico de um órgão público ambiental do Estado - telefone)

"Quero saber mais, vamos bater um papo no Parque para ver como eu posso participar e contribuir."

(Gerente de uma empresa privada do setor florestal - telefone)

"Conte comigo, tudo que você precisar e eu puder ajudar, estarei à disposição, adorei a idéia."

(Diretor de Depto - Prefeitura Municipal - pessoalmente)

Neste primeiro contato, com exceção de um, todos foram extremamente receptivos, favoráveis à idéia do projeto, mesmo com alguns sem entender exatamente o que era pretendido, e o que era a Agenda 21.

A partir de muitos outros contatos, (reuniões), ouvi algumas declarações incisivas quanto à contribuição da participação dos outros grupos (alunos, professores, etc), no sentido de ser nula.

"Os moradores não têm nada a falar, eles precisam é ouvir e fazer o que os técnicos determinarem."

"O que alunos universitários podem fazer? Que poder eles têm?"

"Os professores (ensino fundamental e médio), ah, são fraquinhos!"

"Nós já sabemos o que tem que ser feito, não é interessante um falar para o outro, pois não será nenhuma novidade, não é questão de opinião, é fato." 
Com estes comentários, senti uma certa vaidade e discriminação, uma resistência à técnica do grupo focal, onde quem estaria ouvindo as opiniões ou os "fatos" seriam apenas os próprios técnicos e eu, como moderadora.

Considerando as conversas de reuniões e de "corredores" com alguns técnicos, refleti que talvez eles tivessem razão, e um grupo focal eliminaria uma oportunidade para troca de informações, reflexões e debates com os outros grupos da pesquisa. Vi no grupo focal, um risco de fracasso quanto à participação destes técnicos, que poderiam não comparecer, por não reconhecerem nisto algo gratificante para eles.

Fazendo estas ponderações, decidi realizar como técnica substitutiva ao grupo focal, um microevento intitulado de: "Encontro Técnico Ambiental" em formato de mesa redonda composta de 9 pessoas, que ao meu ver significou um forte atrativo para a participação.

Compreendendo a participação também em sua dimensão subjetiva (Sawaia, 2001), é necessário buscarmos formas para contemplar suas necessidades íntimas ao mesmo tempo que ele é chamado a inserir-se nos processos de tomada de decisão nos rumos da sociedade.

Assim, acredito ter sido o Encontro a melhor opção, pois tornou-se, de fato, um espaço constituído de muitas informações importantes sobre a história da Serra, a legislação geral e específica, ecologia, os recursos naturais, a fiscalização, os entraves do governo municipal e estadual, além das reflexões e debate com a participação da platéia formada por outros técnicos, por alunos universitários e poucos moradores.

Este Encontro possibilitou ainda a divulgação do projeto na mídia (TV local e jornais impressos) de forma ampla na região, o que é positivo, considerando que é "com grande influência dos meios de comunicação que a humanidade, hoje, toma contato com os problemas ambientais e procura rediscutir os seus modelos de desenvolvimento e sua atuação no meio ambiente" (Ramos, 1995, p.14). 
De forma geral, com base na minha grande proximidade com este grupo, antes e durante a pesquisa, tentei visualizar a agenda diária dos técnicos, enxergando então, um cotidiano duramente marcado pelo profissional, com as características rígidas e tradicionais exigidas em suas áreas e funções.

Considerar o cotidiano, pode ser um caminho para compreensão da trama social em que nos inserimos, constituindo-se, segundo Maffesoli (1998, p. 98), "o grande interesse sociológico: integrar no conhecimento o que está mais próximo; inventar, destacar todos aqueles fragmentos, aquelas situações minúsculas, que por sedimentação, constituem o essencial da existência."

A partir daí, considerando que o que queria deles relacionava-se direta ou indiretamente ao cotidiano profissional dos mesmos, seria viável então envolvê-los numa técnica que fosse ao encontro disto.

Acredito que houve a satisfação do grupo por terem feito aquilo como parte de seu cotidiano técnico profissional, ou seja, expor conhecimentos e argumentar, apontar problemas, propor e discutir soluções. Isto aconteceu de forma que reforçou a verdade por eles indicada, pelo fato de estarem ali representando o conhecimento e o poder para um público, que se colocou como receptor destas representações, embora este público também tenha participado de forma crítica.

A afirmação acima revela-se também por algumas observações destes técnicos quanto à participação deles em processos decisórios da sociedade:

"Ah! Fui participar de uma reunião, achando que era técnica, cheguei lá era uma "balela". Gente falando de sentimentos, de sonhos, enquanto deveriam falar de coisas técnicas. Não caio mais nessa."

"Nosso tempo é muito curto. Não podemos ficar participando de reuniões para discutir certas coisas que nós já sabemos como fazer e porque fazer. Os outros, sim, precisam aprender para fazer a coisa certa." 
Assim, concluí que a satisfação se daria se a técnica utilizada não colocasse em evidência os sentimentos, e sim conhecimentos, sendo esta a forma de que poderiam participar, pois, segundo a visão deles, é tecnicamente que poderiam contribuir.

Baseada em observações, em algumas entrevistas e nas inúmeras conversas formais e informais que mantive ao longo de quase 2 anos com vários técnicos, arrisco-me apontar alguns possíveis motivos de participação destes nesta pesquisa e em seus desdobramentos.

Refiro-me a motivos aparentes de participação que talvez não expressem a realidade da subjetivação dos técnicos desta pesquisa, mas expressam as subjetivações e objetivações de uma instituição, uma política, uma condição, um cargo; enfim, de estruturas físicas ou não, cada qual com sua ideologia, que tornam a participação um objetivo de suas realizações subjetivas.

Exemplifico isto com a fala de um técnico em situação e função política institucional:

"Henriqueta, precisamos deste documento teórico sobre a elaboração de um processo educativo, apenas para que os governantes superiores abram as portas para nós. Qualquer coisa serve, é só para o "cara" ver."

Falo, então, da participação de uma instituição composta de sujeitos movidos pelo institucional e profissional.

Neste caso o sujeito busca atender as subjetivações de uma instituição, garantindo talvez algumas de suas subjetivações voltadas ao poder econômico e político, independendo muitas vezes das suas convicções ideológicas e história de vida.

Mesmo que o sujeito, por seus motivos subjetivos, tenha escolhido inserir-se, participar de determinada instituição por apresentar afinidades com 
esta, na hora de representá-la, assumirá os motivos daquela que ele representa e não os seus, tornando-se assim um objeto institucional.

Dentro da "Pedagogia do Oprimido", (Paulo Freire, 1987, p.36), podemos visualizar a situação destes sujeitos que "querem ser, mas temem ser, são eles e ao mesmo tempo são o outro introjetado neles, como consciência opressora."

Assim, em dualidade interna, podem entrar numa "luta entre seguirem prescrições ou terem opções; entre serem espectadores ou atores, entre atuarem ou terem a ilusão de que atuam, na atuação dos opressores" (Paulo Freire, 1987, p.36).

Considero, também, alguns poucos casos, onde o sujeito com deveres institucionais a cumprir, procede de forma crítica e consciente, assumindo ainda seus princípios e desejos, independente daquilo que ele está representando, que pode exigir ou não a sua anulação.

Entre os motivos aparentes desta participação, ressalto os mais evidenciados: obrigação, dever, paixão e política, sendo algumas vezes integrados.

Os motivados pela obrigação e política, normalmente encontram-se no poder público, que procurará manter a postura adotada como correta e adequada. Para isto, seus sujeitos terão que participar daquilo que se caracterizar como importante para esta postura, independente de sua concepção íntima quanto ao assunto tratado.

Apresento a seguir algumas considerações e indagações que me levaram a evidenciar o motivo de obrigação e política na participação de alguns técnicos desta pesquisa.

Não seria politicamente adequado, após divulgação ampla e convite, que uma Prefeitura Municipal não participasse da construção de uma Agenda 21 Local.

Também não seria politicamente adequado, um governo que se elegeu sob o slogan "governo participativo", ausentar-se de processos participativos que buscam o seu envolvimento e parceria, visando à melhoria da qualidade de 
vida e conservação de recursos naturais de uma área considerada símbolo para a cidade.

Portanto, o assunto torna-se relevante para a participação deste governo, no mínimo para manter o controle democrático, informando-se do que sua população tem se ocupado e pré - ocupado. Na melhor das hipóteses este governo poderia participar de um engajamento na contribuição para emancipação de sujeitos, o que até o momento infelizmente parece ser descartado.

O técnico inserido no governo deve representá-lo de forma a garantir sua seriedade e competência, encontrando-se aí, sua obrigação de participação.

Encontrei também no poder público os motivados pela paixão e pelo dever, e estes demonstraram maior entusiasmo e dinamismo, empenhando-se em participar, conforme indicações deles a seguir:

"Henriqueta, estou à disposição, posso ir fora do meu horário, não tem problema, será um prazer falar sobre leis, sobre a Serra, sobre caminhos legais que podem e devem ser seguidos."

"Olha, nós temos que comparecer nesta reunião, se os outros não forem, eu vou. É nosso dever estar presente, temos que expor nossa opinião, argumentações. Este é o momento, não podemos nos intimidar. Se eu não puder comparecer como promotor, irei como cidadão, isto é do meu interesse."

"Mulher, você tá no caminho certo, as coisas por aqui são complicadas, não tenho como agir sozinho, mas agora quem sabe? Eu uso meu carro para este trabalho, eu invento coisas que não são para torná-las verdadeiras. Tá difícil ir na contracorrente, mas enquanto tiver forças continuarei, pode ter certeza, não vamos deixar que esta Serra desapareça, estes caras tem que acordar." 
Estes sujeitos reconhecem o dever de sua participação mas, diante de dificuldades, inventam, criam, deslocam-se deste dever para participar de outras formas, pois o importante é atuar, fazer parte, fazer algo que queiram.

De acordo com Sawaia (2001, p.9), "o que alegra o homem está na disposição de pensar e agir por si próprio e esta concepção livra a participação da obrigação, da moralidade e da renúncia."

Finalizando este grupo, quero destacar, neste momento, um fato ocorrido, para contar um resultado que poderia ter sido positivo.

Poucos dias após o "Encontro Técnico Ambiental", fui procurada pela Prefeitura Municipal de Mogi das Cruzes, para apresentar maiores informações sobre o documento "Agenda 21", formas de sua elaboração, experiências já ocorridas, enfim, detalhes para que pudessem compreender melhor o tema.

Ansiosa por saber o objetivo de tal interesse, fui logo perguntando quais eram as intenções com tantas perguntas, obtendo como resposta: a elaboração da Agenda 21 de Mogi das Cruzes.

A princípio fiquei extremamente feliz, por considerar este ato uma real demonstração de interesse nesta pesquisa, com possibilidades de comprometimento não só com a Agenda 21 da Serra do Itapety, mas também com todo o município.

Após esta reunião, solicitaram-me que elaborasse no prazo de 3 dias, uma proposta de construção de Agenda 21 Local para Mogi.

Apresentei argumentações quanto à complexidade do assunto, enfatizando ser necessário um tempo bem maior e outras reuniões para que a proposta fosse realizada.

Sem sucesso, concordei em entregar na data marcada, apenas um esboço de um ante projeto, para que pudessem dar um passo inicial em direção à construção da referida Agenda.

Desta forma, entreguei o combinado, que a pedido da Prefeitura Municipal por efeitos de formalidades, foi apresentado através da Bio Bras, 
ONG de pesquisa, educação e proteção ao meio ambiente da qual também sou integrante.

Assim, no dia 08 de março de 2001, durante a realização do evento regional - "Fórum de Desenvolvimento Sustentável do Alto Tietê" - com a presença de diversas autoridades do governo federal e estadual, foi assinada uma carta de intenções da Prefeitura Municipal de Mogi das Cruzes com a Bio Bras, comprometendo-se em iniciar a construção da Agenda 21 local no prazo máximo de 3 meses.

Tal compromisso, firmado pelo Prefeito Municipal, na presença do Diretor de Florestas e Biodiversidade do Ministério do Meio Ambiente, que naquele momento representava o Ministro, além da satisfação explícita e elogios da autoridade local, rendeu matérias na TV local e imprensa escrita, que destacou o município como primeiro da região a ter uma Agenda 21.

Quanto à prática deste ato, esperamos até hoje por alguma manifestação da Prefeitura Municipal, que após o evento não mencionou mais o assunto, a não ser numa situação provocada pela Câmara Municipal em setembro de 2001, que será detalhada nos resultados com o grupo dos vereadores.

\subsection{Alunos universitários}

Os alunos das Universidades Braz Cubas e de Mogi das Cruzes, participantes desta pesquisa, dividem-se em $50 \%$ residentes em "repúblicas" de Mogi das Cruzes e a outra metade distribuída em residências fixas deste mesmo município ou municípios vizinhos, como Poá, Itaquaquecetuba e São Paulo.

Eles têm idade média de 22 anos e inseriram-se neste projeto por motivos variados.

O primeiro interesse destes alunos em participar desta pesquisa, ocorreu pela oferta do curso e estágio em "Educação Ambiental para Sociedades 
Sustentáveis e Conservação da Serra do Itapety" com uma série de representações para eles conforme segue:

"Um curso gratuito, seguido de um estágio, tudo num período de 6 meses! Quem não quer? “

"Eu já ouvi falar bastante do CEMASI e da Serra do Itapety, quero muito fazer parte disso."

"Ah! Como estudante de Biologia preciso estar em contato com a fauna e flora e ajudar a conscientizar as pessoas da importância disso tudo, então acho que este curso vai ser muito bom."

"O que eu quero mesmo é aprender, ajudar, poder participar."

"Eu conheço bem a Serra do Itapety, então acho que poderei ajudar em alguma coisa que for preciso."

"Nunca trabalhei com nada disso, mas quero muito começar, esta é a oportunidade que eu esperava."

"Não estou fazendo nada, além da faculdade, quero me ocupar com alguma coisa boa, adoro natureza, trilhas..."

Estes são trechos de algumas explicações dadas pelos alunos, durante conversa individual, sobre o porquê deles se interessarem pelo curso e estágio, numa tentativa de captar qual a motivação de cada um para participar inicialmente de um curso e futuro estágio como parte de um projeto. 
Percebi que este curso representava para os alunos o conhecimento, a ocupação do tempo ocioso, o contato com a natureza, a realização da boa ação especializada, a vaga no CEMASI, a oportunidade de fazer parte, de pertencer.

Estas representações são os desejos contidos de participação imanente à espera de uma oportunidade que propicie sua realização.

A oportunidade - o curso - significou esta realização pessoal, e também um instrumental pedagógico para a participação pelo outro, pois os alunos livres de seus motivos subjetivos, passaram a atuar pela melhoria da qualidade de vida e conservação da Serra do Itapety.

O desenvolvimento desta estrutura pedagógica pelo coletivo não significa que os alunos automaticamente passariam a incluir o outro em suas subjetivações, porém, algumas falas e fatos indicam esta ocorrência.

As falas, quase no término do curso:

"Ah, Henriqueta, agora que estou sabendo todas estas coisas, não posso ficar sem fazer nada, quero continuar, quero mudar, alguém tem que lutar por tudo isto."

"Olha, mesmo que eu não tenha "bolsa", não faz mal, eu preciso fazer alguma coisa pra melhorar, ficar só olhando, depois de tudo que aprendemos é um desperdício."

"Estou disposta a mobilizar os alunos, a comunidade, quero dedicar meu tempo para isto, não dá para ficar vendo tudo de braços cruzados, estando conscientes como estamos agora."

Os fatos após o término do curso, estendendo-se até o dia de hoje (10/03/2002): 
- Seis alunos continuam fazendo estágio no CEMASI, num projeto no Parque Natural Municipal;

- Dois alunos organizaram e estão coordenando um grupo de universitários para mobilizações em prol do meio ambiente em Mogi das Cruzes e região;

- Um aluno levou a idéia do projeto da Agenda 21 da Serra do Itapety, para exposição fora do município.

Partindo do pressuposto que estes alunos necessitavam de um repertório esclarecido e crítico, para que a participação pelo coletivo se desse de forma ativa, este curso foi trabalhado no sentido de propiciar informações, reflexões e práticas, procurando alcançar, mesmo que minimamente, uma transformação da realidade encontrada.

A realidade a que me refiro, trata da manifestação aparente destes alunos com inocência, ausência de informações e criticidade ou ainda "deformações" provocadas pelos processos dominantes da educação formal e não formal em que nos inserimos.

Em dinâmicas de grupo eles puderam falar, escrever e conversar sobre suas idéias ou concepções de educação ambiental livremente:

"EA é a conscientisação (sic) de como viver bem dentro de um ecosistema (sic), depredando-o o mínimo possível."

"EA é fazer o máximo para conseguir orientar e explicar a importância da preservação da fauna e flora."

"EA é informar qual importância do ecossistema tem para nós."

"EA é ensinamento de como funciona um ecosistema (sic), como cuidar e preservar o mesmo." 
"É a maneira de como preservar toda forma de habitat e nicho ecológico."

Manifesta-se assim uma educação ambiental com visão restrita à biologia e Ecologia, além de configurar-se na educação "bancária" (Paulo Freire, 1987), ausentando-se de qualquer conexão com outras idéias.

Paulo Freire (1987) disserta sobre este tipo de educação que consiste em depositar no educando uma série de conteúdos, que devem ser fixados, memorizados, onde o educador, "dotado do saber", doa, numa transmissão de conhecimentos, toda sua verdade àqueles que nada sabem.

E esta educação ambiental, com perspectiva unidirecional que considera o outro um depósito de informações, é que foi apontada pelos alunos, como uma das principais contribuições que poderiam dar para a qualidade de vida na Serra do Itapety.

Demonstraram atribuir um grande valor à educação ambiental, assim como, quase único caminho que estariam dispostos a seguir para envolveremse com a Serra do Itapety, mesmo que inconscientemente voltados para a educação "bancária".

Estes resultados me provocaram várias preocupações que perduram até hoje, não apenas com estes alunos que participaram do curso, mas com todos aqueles que se interessam pela educação ambiental.

Percebi nas intervenções com os alunos, que uma grande quantidade deles mostram-se ansiosos por engajar-se na educação ambiental, referindo-se a ela como a salvação dos problemas do mundo, restringindo sempre este mundo a biologia e ecologia.

Isto serviu para orientar-me logo no início do curso, sobre os caminhos que deveria percorrer com estes alunos a fim de que refletissem sobre dimensões mais amplas para a educação ambiental. 
Considerei que apenas o curso não seria suficiente para trabalhar as inúmeras relações da educação ambiental conciliadas ao desenvolvimento do potencial dos alunos.

Desta forma, a continuidade de alguns deles através do estágio no Projeto, conforme era previsto, seria uma opção para um enriquecimento, além da tentativa de minimizar as minhas preocupações já apontadas. Devido à impossibilidade estrutural e financeira, apenas 07 alunos puderam integrar a equipe de estagiários do projeto, sem nenhum tipo de remuneração.

A partir daí, estes alunos passaram a acompanhar as atividades desenvolvidas com outros grupos da pesquisa, sendo que em alguns momentos eles se integravam com os vários sujeitos envolvidos, possibilitando trocas sociais e culturais.

Sentia um grande prazer em ver a dedicação extremada destes alunos/estagiários, sujeitos da pesquisa, e algumas vezes pesquisadores também, trazendo-me informações que colhiam espontaneamente nos bastidores dos diversos atores aqui envolvidos.

No acompanhamento das atividades, passaram a analisar criticamente o que estavam vendo, ouvindo ou percebendo, demonstrando uma certa superação das iniciais manifestações de ingenuidade, ausência de criticidade, de informações e mesmo da restrita visão de educação ambiental.

Isto pode ser evidenciado através de alguns comentários deles:

“... A educação ambiental deve incluir nossos sentimentos, pois estes sentimentos podem direcionar nossas atitudes que serão ruins ou boas, dependendo de como forem trabalhados em nós. Nós somos um grupo, estamos construindo espaços de amor, de cidadania, de informações..." (comentário feito após apresentação de seminários por estes alunos com a presença de outros alunos não participantes do curso). 
“... A plantinha e o bichinho vão desaparecer se ficarmos falando apenas deles, as explicações sobre eles podem ser dadas nas aulas direcionadas para isto, nosso trabalho é mais amplo, tem que envolver outras coisas que extrapolam a fauna e flora..."

(comentário de uma aluna/estagiária para outro aluno não participante do curso).

“...Nossa! É incrível como estes professores desconhecem a Serra do Itapety e ao mesmo tempo ou querem fazer trabalhos à distância na área ou criticam o que é feito sem estarem informados do que já ocorre..."

(comentário no grupo de alunos/estagiários que acompanhou algumas entrevistas com os professores universitários).

Hoje, os alunos envolvidos com a Serra do Itapety não são apenas aqueles que fizeram o curso/estágio, outros integram de formas variadas, o grupo de estudantes universitários interessados e participantes da construção da Agenda 21.

Estas formas de participação vêm ocorrendo através do estágio no Programa de Uso Público do Parque com dimensões educativas ampliadas na execução dos trabalhos, através da Comissão da Agenda 21 da Serra do Itapety e, também por meio do grupo criado por estes alunos para militância na área ambiental e social.

Ao todo, existem cerca de 15 alunos participando freqüentemente de reuniões, eventos, debates, reflexões e outras atividades, sendo algumas destas organizadas por eles.

Isto ocorreu devido à divulgação feita por palestras, oficinas e reuniões realizadas não só por mim, mas também pelos próprios alunos/ estagiários.

Vejo nestes poucos alunos, participantes da construção da Agenda 21 da Serra do Itapety e também de outros assuntos ambientais da região, uma 
esperança próxima, não somente de ampliação do número de estudantes universitários envolvidos, mas também na busca de um fortalecimento para ação crítica e criativa, com fins a emancipação de sujeitos.

É na análise desta esperança sentida por mim, que me apoio em Espinosa (1989), para acreditar em minha própria potência de ação movida por este sentimento e que, segundo ele, é da alegria instável por imaginarmos algo futuro com algumas dúvidas, mas podendo perfeitamente transformar-se em segurança.

\subsection{Moradores da Serra do Itapety}

Ressalto aqui meu descontentamento no envolvimento deste grupo na pesquisa, para o qual havia planejado a aplicação de intervenções educativas, que foi prejudicado mais uma vez pela ausência de recursos financeiros.

Este grupo de fundamental importância, apontado por todos os outros grupos desta pesquisa, como o maior problema da Serra do Itapety, será objeto e sujeito de atividades educacionais que planejo realizar ainda em 2002.

Não será possível constar aqui os possíveis resultados destas ações,

mas deixo claro que esta pesquisa/intervenção continuará independente do meu vínculo acadêmico.

Foram aplicados, pelos alunos universitários - estagiários deste projeto, questionários em 213 residências, nos pontos previamente selecionados empiricamente, de acordo com as aglomerações demográficas da Serra do Itapety, esta por sua vez definida em mapa.

É preciso destacar, que não existe um levantamento ou cadastro das propriedades da Serra do Itapety, na Prefeitura Municipal de Mogi das Cruzes e na Secretaria Estadual do Meio Ambiente de São Paulo, que pudesse orientar sobre o seu uso e ocupação do solo, nem mesmo sobre o número exato de propriedades. 
Esta é a exigência que o Ministério Público do Estado de São Paulo vem fazendo há tempos para a SMA-SP, sendo condição fundamental para a regularização de propriedades, e cumprimento da legislação da Serra do Itapety.

Desta forma, os resultados deste grupo centram-se principalmente nas respostas aos questionários e em algumas conversas mantidas com os moradores.

Do universo da pesquisa, $61 \%$ dos moradores são provenientes do próprio município, enquanto $21 \%$ são de outros municípios do Estado de São Paulo, $16 \%$ de outros estados e $2 \%$ de outros países.

A ocupação na Serra do Itapety ocorreu nos períodos indicados, conforme quadro:

\begin{tabular}{|c|c|c|}
\hline PERÍODO DE OCUPAÇÃO & NÚMERO DE FAMÍLIAS & $\%$ \\
\hline 1 a 10 anos (1991 a 2001) & 114 & 54 \\
\hline 11 a 15 anos (1986 a 2001) & 22 & 10 \\
\hline 16 a 20 anos (1981 a 2001) & 18 & 8 \\
\hline 21 a 30 anos (1971 a 2001) & 27 & 13 \\
\hline Acima de 30 anos (1920 a & 32 & 15 \\
\hline 2001$)$ & & \\
\hline
\end{tabular}

Quadro 3 - Período de ocupação das famílias na Serra do Itapety.

Esperando compreender melhor e buscar um pouco das origens da ocupação da Serra do Itapety, através dos motivos pessoais de cada família para instalação nesta área, fizemos a pergunta a seguir, apresentando suas respostas através do gráfico de ordenação de motivos e explicações dos moradores. 
1) Porque escolheu a Serra do Itapety para morar?

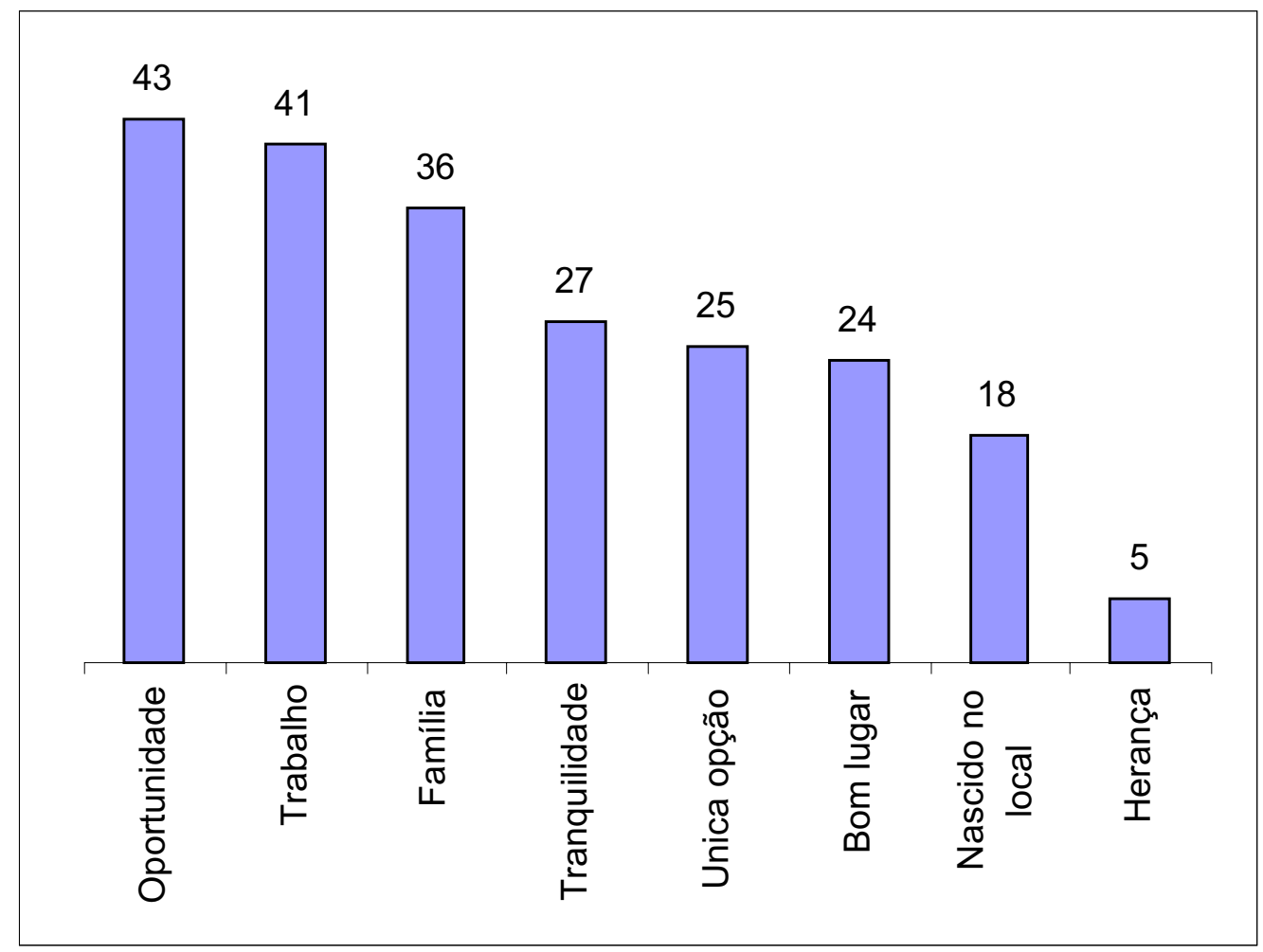

Figura 7 - Motivos da escolha de moradia na Serra do Itapety.

Encontramos uma maioria de moradores que ocupou a Serra do Itapety, devido ao que chamaram de oportunidade, referindo-se às facilidades encontradas para aquisição de terreno barato e sem muitas burocracias, assim como aluguéis baratos, comparados com outras localidades do município.

Aproximando-se deste item, existem aqueles que se referiram à única opção, citando a invasão como o caminho para não ficarem nas ruas, e outros que também obtiveram facilidades, como terrenos em loteamento com preço abaixo do normal, acessível a todos, representando isto a única opção de construção de moradia.

Unindo estes dois itens (oportunidade e única opção), poderíamos deduzir que algumas das origens da ocupação desordenada da Serra do Itapety surgiram na própria oferta que o município apresentou. 
Com um grande número de pessoas em situação econômica desfavorável, mas, com um mínimo de condição para sustentar propostas únicas, provenientes de imobiliárias e corretores de imóveis que por sua vez têm ou deveriam ter o aval de órgãos públicos responsáveis pela fiscalização, tornou-se viável que estes moradores ocupassem o local

O item trabalho refere-se a empregos no município de Mogi das Cruzes, mas não necessariamente na Serra do Itapety. Aqui estão os moradores deslocados de outros bairros de Mogi das Cruzes e também aqueles vindos de outros municípios e estados ávidos por encontrarem emprego nesta cidade, sendo a Serra do Itapety o local mais adequado para eles morarem, pelos mesmos motivos citados acima.

A terceira opção mais apontada - família - poderia encaixar-se em qualquer uma das demais opções, pois neste item, os moradores mencionaram, sem especificações, a existência de diversificados problemas que tiveram, envolvendo toda a família, sendo então para eles, este o motivo final da escolha da Serra do Itapety para moradia.

Aqueles que indicaram a tranqüilidade da Serra do Itapety são provenientes de localidades agitadas pela vida urbana, de outros municípios e estados e em sua maioria com situação econômica favorecida, ressaltando este item como uma busca para melhoria da qualidade de vida.

De forma geral, comprovou-se neste contato com os moradores, uma ocupação extremamente facilitada pelo poder público, que hoje ameaça não só os recursos naturais, históricos e culturais da área, como também, a vida destas pessoas que deverão, no mínimo, ajustar-se às leis.

Ressalte-se também a ineficiência dos órgãos públicos responsáveis pela fiscalização da área, principalmente, após a vigência da lei 4529 de 1985 , que determina o zoneamento do local tendo como objetivo, entre outros, "restringir e condicionar o parcelamento do solo, visando à proteção ambiental, mediante o controle da densidade demográfica, a preservação da 
permeabilidade do solo e a manutenção das reservas florestais" (Lei 4529/85, p.1).

O período de maior ocupação na Serra do Itapety, foi justamente após esta lei, que praticamente não teve significação para a ocupação ordenada que deveria ocorrer. Firmou-se o inverso, com uma realidade atual de propriedades irregulares, em áreas de risco e áreas de proteção ambiental restrita.

Dando continuidade ao questionário, a próxima pergunta tinha o objetivo de resgatar um pouco da memória dos moradores, assim como, captar suas percepções sobre um passado próximo ou distante.

2) Como era a Serra do Itapety quando veio morar aqui?

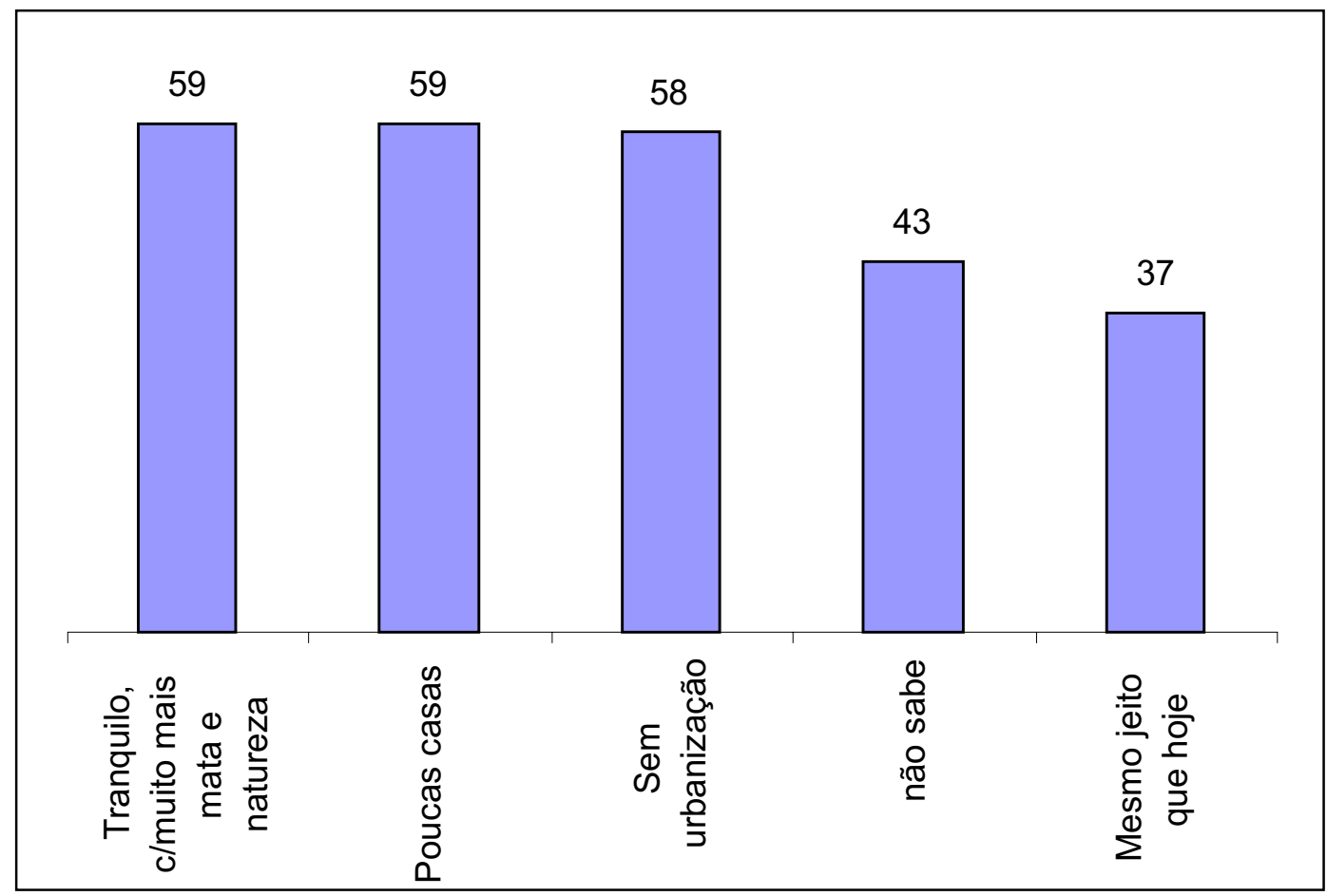

Figura 8 - Lembranças da Serra do Itapety.

O gráfico mostra uma memória relacionada à percepção de tranqüilidade e natureza, com a ausência de muitas casas ou urbanização, confirmando as lembranças da natureza mais farta. 
Por outro lado, encontramos os esquecidos e indiferentes, que sem lembrar ou perceber, não notaram nenhuma alteração no local em que vivem. Estes são os moradores mais recentes, que não tiveram a oportunidade de encontrar a Serra do Itapety em seu auge de preservação.

Instalaram-se no ponto baixo da Serra, em área de risco, com grande ocupação desordenada, tornando-se assim difícil a percepção ou resgate de memória de tranqüilidade, mata ou natureza, oposto ao que ocorre com os moradores que ocupam a área há mais de 20 anos.

3) Como gostaria que a Serra do Itapety estivesse hoje?

O objetivo desta pergunta, relacionou-se à anterior, na tentativa de reconstrução do passado e construção de um presente desejado na ótica dos moradores.

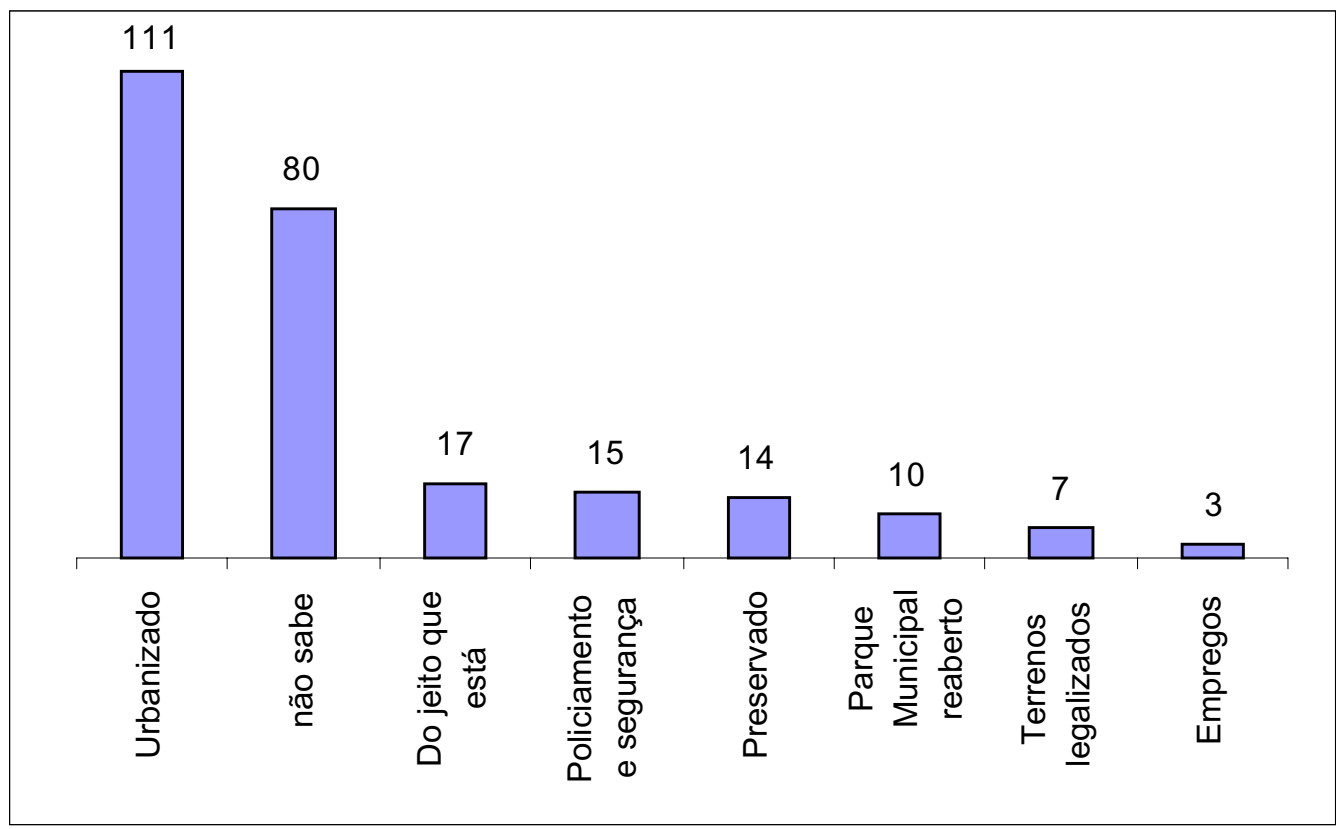

Figura 9 - Desejos dos moradores para a Serra do Itapety.

Percebemos aqui um contraste do passado - presente desejado, onde a lembrança com a percepção de tranqüilidade e natureza perdeu espaço para aquilo que categorizei como urbanização. Nesta desejada urbanização, 
incluem-se, asfalto, supermercados, postos de gasolina, água, esgoto, luz elétrica, centros de lazer, praças e etc.

Destacou-se também um presente desejado indeterminado, sem formas, sem desejos, manifestado por aqueles que dizem não saber como gostariam que a Serra do Itapety estivesse hoje e ainda alguns que não percebendo diferenças entre passado - presente satisfazem-se com o que têm.

4) O que a Serra do Itapety representa para você?

Esta pergunta foi feita com a intenção de captar percepção ou reforçar as outras captadas nas perguntas anteriores, visando encontrar uma essência da representação da Serra na vida destes moradores.

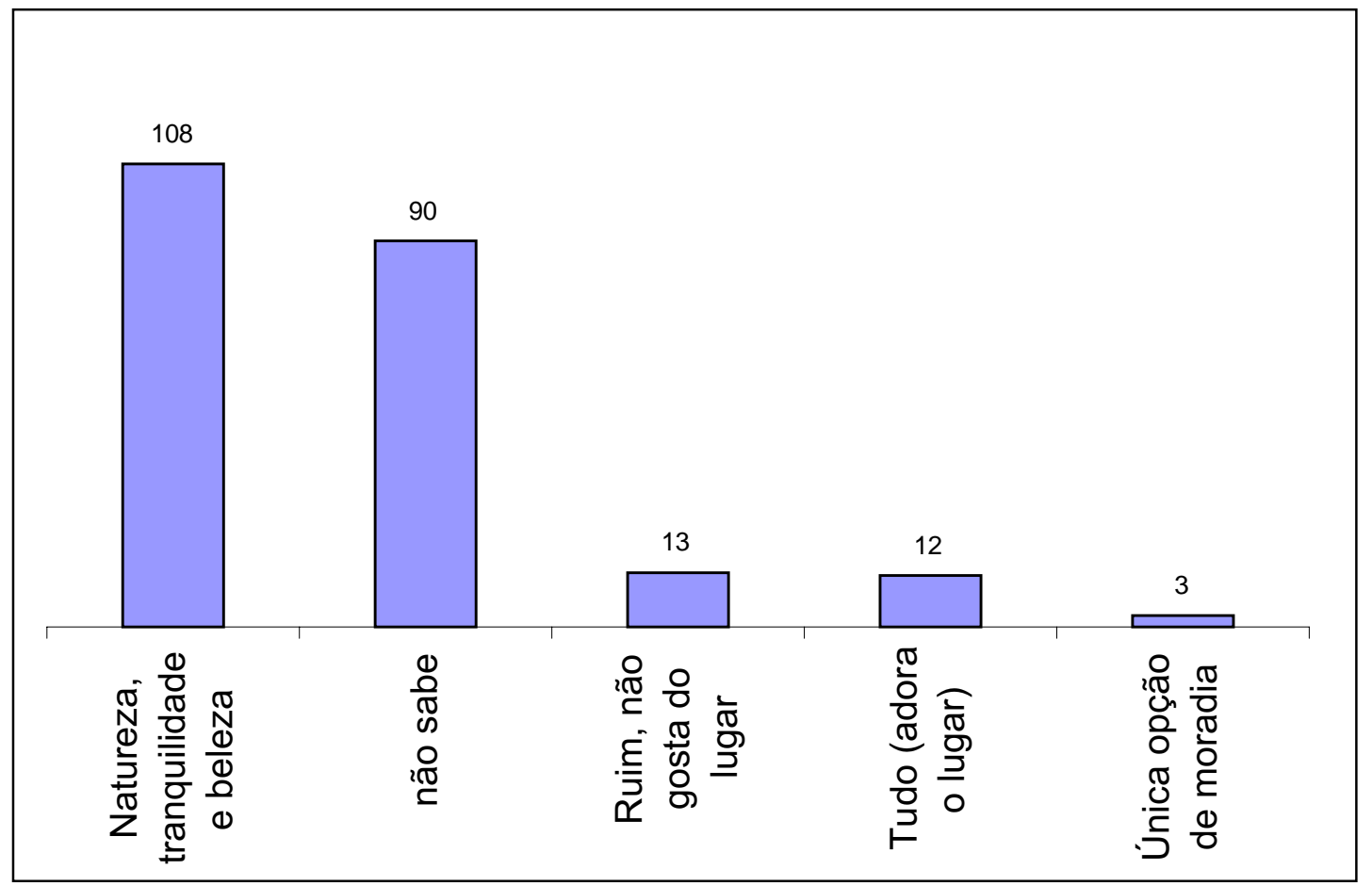

Figura 10 - Representações da Serra do Itapety.

Houve uma repetição ou reforço das idéias dos moradores, desta vez, manifestadas como representação de seus sentimentos sobre a Serra e não como desejo ou memória da mesma. 
Novamente encontramos um contraste, com a representação, reforçando idéias de natureza, tranqüilidade e bem estar acrescidas de beleza e por outro lado presente também a não idéia, o amorfo, o impensado, talvez o nãosentido, por isto não-sabido.

Enquanto a memória sobre e a representação da Serra gira fortemente em torno da natureza, tranqüilidade e beleza, os desejos manifestados para a vida presente nesta concentram-se em urbanização.

Talvez na concepção destes moradores haja uma perfeita normalidade em conciliar o urbano com a natureza e tranqüilidade, ou talvez eles estejam demonstrando que seus desejos não são para a Serra do Itapety e sim para suas vidas em algum outro local que seja possível a urbanização.

Se voltarmos no gráfico 1 (porque escolheu aqui para morar), podemos encontrar justificativas para esta afirmação.

Existe uma maioria que não escolheu a Serra do Itapety para morar e sim viu-se obrigada a instalar-se nela por motivos de trabalho, oportunidades fáceis, família, herança e outros que de alguma forma poderiam levar a ocupação para qualquer outra área.

Desta forma, torna-se difícil desejar, sentir, pensar em algum significado para um lugar que não escolhemos para morar, mas que fomos levados pelas circunstâncias a ocupá-lo.

Pode encontrar-se aí o motivo para um grande não-saber manifestado na memória, desejos e representações da Serra do Itapety. 
5) Você tem algum sonho para este lugar?

Esta pergunta objetivou conhecer um pouco mais as aspirações, os desejos, as transformações pretendidas, enfim, quisemos construir o perfil destes moradores tomando como base também os seus sonhos.

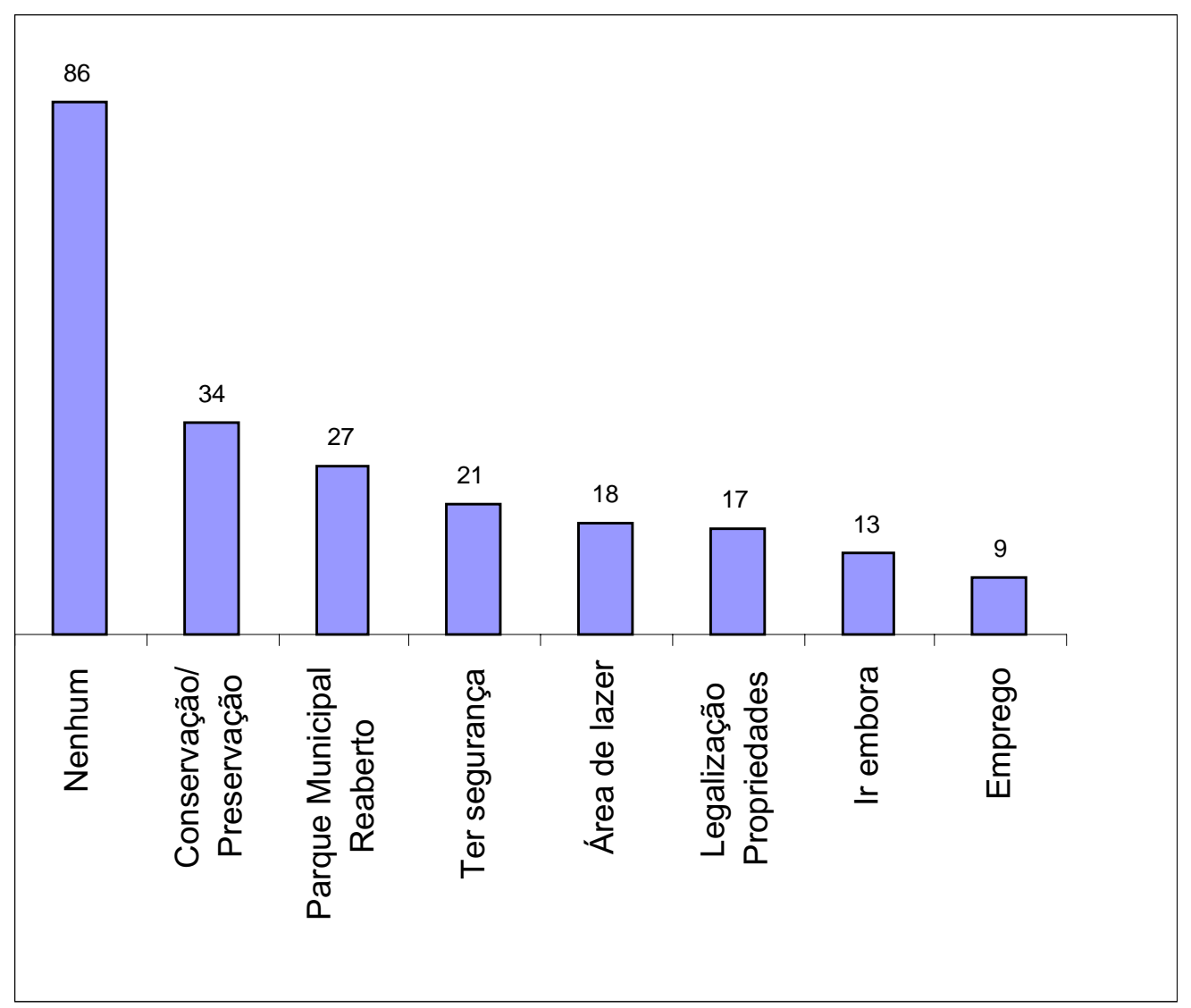

Figura 11 - Sonhos para a Serra do Itapety.

Analisando este gráfico apresento uma classificação dos sonhos/desejos da seguinte forma, lembrando que esta categorização é válida apenas para o que foi manifestado pelos moradores:

1) Sonho/necessidade - são os sonhos que vão ao encontro das necessidades básicas individuais e algumas coletivas. O sonho se constrói a partir daquilo que falta, que se ausenta, que é necessário para propiciar um bem estar, mínimo que seja. 
Esta necessidade é de ordem material, concreta, como manifestaram os moradores: financeira, recreativa ou de legalidade. Incluem-se aqui portanto os itens: Parque Municipal reaberto, área de lazer, ter segurança, legalização de propriedades e emprego.

Nesta categoria encontram-se os moradores recentes e antigos, de poder aquisitivo baixo e alto.

Os sonhos aqui não consideram, o local, os sentimentos sobre o local, ou a percepção do local.

2) Sonho/percepção da paisagem - estes partem do recorte que os moradores fazem do ambiente em que vivem, constituindo-se em uma visão sobre a paisagem local, atribuindo importância à área pelas suas características físicas e biológicas.

Entram aqui a preservação/conservação, relacionando-se a concepções ecológicas, estéticas e de qualidade de vida numa interligação com ar puro, água, beleza e tranqüilidade, apresentando-se independente das carências individuais ou coletivas.

3) Sonho/sentimento - aqueles formados com base nos sentimentos das pessoas relacionados a diversos fatores como, o local, elas próprias, o outro, ou tudo isto numa inter-relação. Pode até envolver a percepção que se tenha do local, e até mesmo uma necessidade básica, mas o que move é o sentimento construído é a subjetividade de cada um.

Estes sonhos/sentimentos podem ser positivos ou negativos, presentes ou ausentes.

Explicando-me, quero dizer que os sentimentos podem estimular os sonhos ou neutralizá-los, impedir os sonhos.

O exemplo positivo ou presente, é quando o sonho existe, independentemente da origem do sentimento, este inspira um sonho como é o caso dos moradores que apontaram o item "ir embora". Algum sentimento leva estes moradores a sonharem em mudar-se. 
O exemplo negativo ou ausente, é representado pelo item "nenhum". E o que dizer de um povo que não sonha?

Analisando este item, o mais apontado pelos moradores, percebo que há sentimentos omissos impedindo este povo de sonhar.

Estas pessoas possuem necessidades básicas, possuem uma percepção do local, mesmo que não manifestada e também possuem sentimentos. Nada disso fez com que elas nos apresentassem algum tipo de sonho, mas algumas explicações delas nos orientam para compreendê-las:

"Eu já sou muito velho para sonhar."

"Eu sou apenas caseiro, não posso ter sonhos."

"Ah, sonho é algo que nunca acontece."

Estas frases indicam sentimentos construídos a partir de algo como necessidade, percepção e subjetivações individuais. Estes sentimentos criaram empecilhos para os moradores sonharem, criaram uma negação do sonho. 
6) Quais são os principais problemas da Serra do Itapety?

Pretendemos com esta pergunta obter a direção do olhar dos moradores para os problemas da Serra do Itapety.

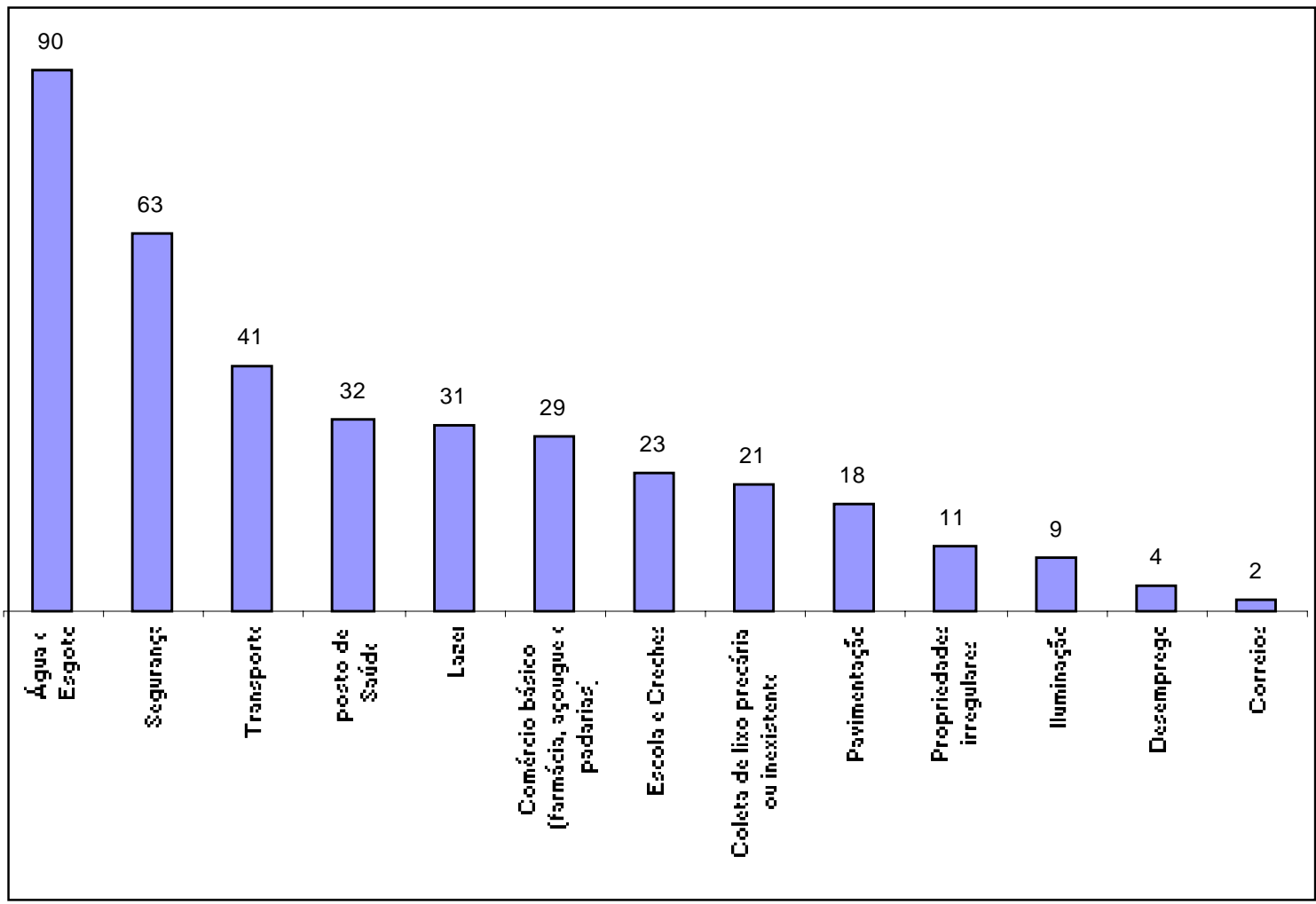

Figura 12 - Problemas da Serra do Itapety.

O quadro é claro ao apontar que os moradores da Serra do Itapety enxergam, sentem e afirmam a existência de problemas que são de ordem básica na vida urbana de qualquer cidadão.

Eles demonstram, com estes problemas, a insatisfação com as condições apresentadas no local em que vivem, mas, por outro lado, demonstram também uma certa incompreensão ou desconhecimento sobre este mesmo local.

Desconhecer ou incompreender, o fato é a existência de uma certa incompatibilidade na conciliação entre vida urbana e Serra do Itapety. Talvez 
isto seja possível sim, mas dentro do ilegal e da perda de mais um patrimônio natural e histórico-cultural.

Desta forma, não haveria uma conciliação, mas uma anulação. A Serra do Itapety deixaria de existir como área de características especiais para o meio ambiente e qualidade de vida de um município e região.

Compreendo com este gráfico a existência de 2 grandes problemas: um dos moradores, conforme apontaram muito bem, que de fato acontece e caracteriza-se como tal, e o outro que se origina deste primeiro, aquele de incompatibilidade da resolução básica destes problemas com as características da Serra do Itapety.

7) Tem alguma sugestão para solução destes problemas?

Por fim, buscamos nos próprios moradores possíveis caminhos para solucionar os problemas identificados por eles, conforme mostra o próximo gráfico de ordenação.

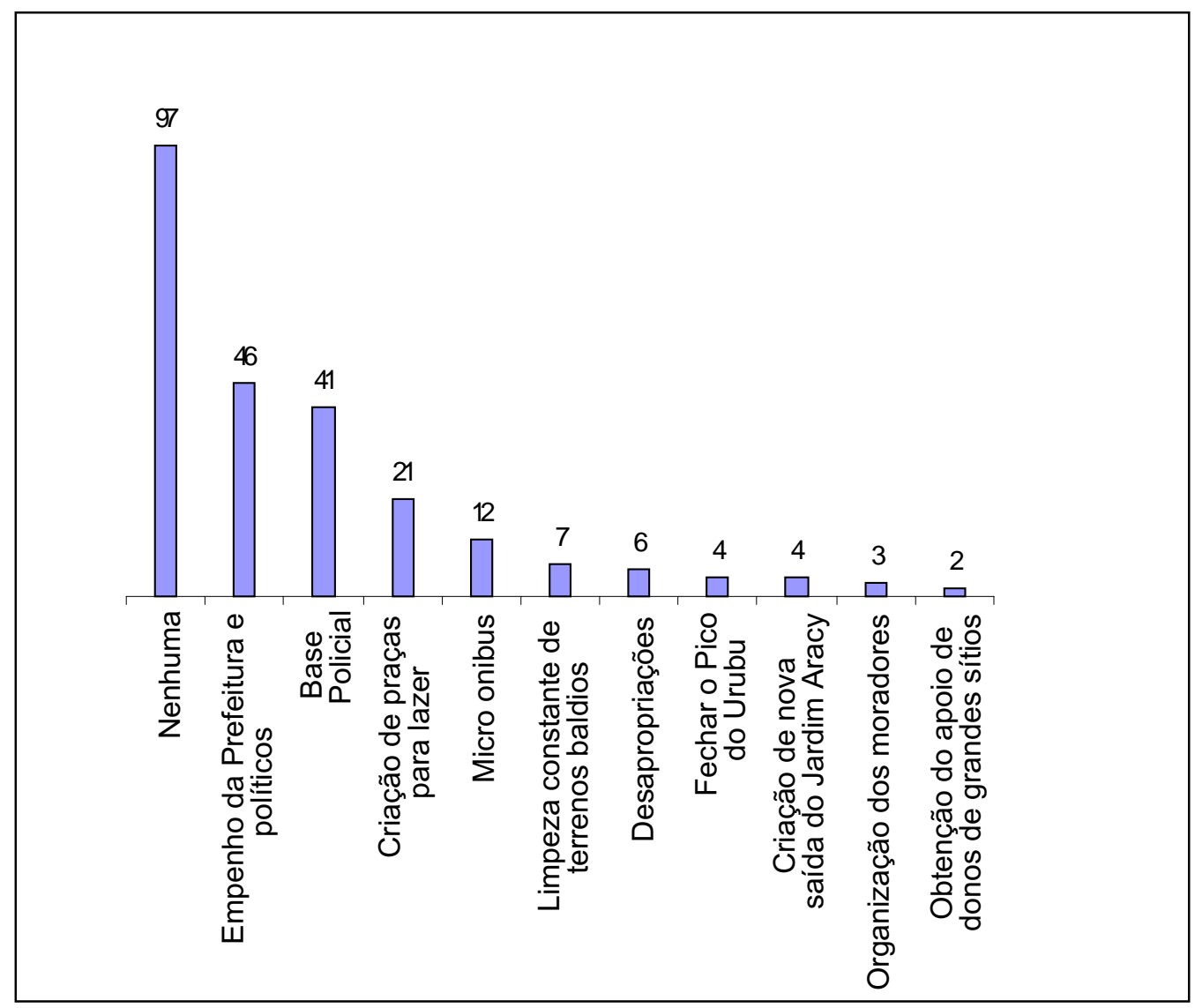

Figura 13 - Sugestões para solução de problemas na Serra do Itapety. 
Acredito termos encontrado outro problema, conforme revela o gráfico, grande parte dos moradores demonstra uma ausência de reflexão sobre seus problemas, quando dizem não ter nenhuma sugestão para solução.

Eles manifestam insatisfação apontando uma série de carências em suas vidas, mas não apontam um caminho a seguir, segundo suas próprias idéias e desejos.

Uma outra boa parte dos moradores aponta algumas sugestões pontuais, que podem e devem ser consideradas pelos governantes responsáveis. Entretanto, pretendo destacar apenas dois itens mencionados - o "empenho da Prefeitura Municipal e participação dos políticos" e a "organização dos moradores".

O motivo do destaque para estes dois itens acontece pela polarização que provocam, tanto em número de pessoas quanto em conteúdo ou abrangência do assunto.

De um lado apresenta-se um grande número de moradores que sugere que seus problemas sejam resolvidos pela Prefeitura Municipal e políticos, caracterizando-se num dever, numa responsabilidade do outro.

Com isto temos um grupo de moradores que fica à espera dos acontecimentos, creditando seus sonhos, desejos e possíveis soluções de problemas para esferas do poder público administrativo e legislativo como garantia do sucesso.

Do outro lado, temos apenas um grupo de 03 moradores que acreditam no sucesso da organização dos moradores como possibilidade de alcançar resolução de problemas.

Neste grupo visualizamos um envolvimento capaz de contagiar outros moradores, num estímulo à potência de ação dos mesmos. 


\subsection{Professores dos Ensinos Fundamental e Médio}

A intervenção neste grupo aconteceu através do curso "Educação Ambiental e Agenda 21", oferecido gratuitamente, recebendo um número de 40 professores inscritos, com apenas 18 comparecendo e participando.

Posso apontar alguns motivos dessa ausência a partir da reflexão sobre este assunto, realizada individual e coletivamente.

Vou comentar um pouco sobre estas reflexões e discussões com o grupo:

Segundo os professores presentes, houve certa dificuldade para fazer a inscrição, pois as vagas eram poucas, e corriam o risco de ficarem de fora, o que acabou acontecendo com muitos.

Existiam facilidades e atrativos para fazer o curso como: ônibus gratuito, certificado e um final de semana no Parque.

Em torno disso, as opiniões do grupo foram:

"É um absurdo. Eles ocuparam o lugar de quem realmente queria participar."

"Como pode, perder uma coisa desta, se eles imaginassem como seria, não fariam isto."

"Olha, Henriqueta o problema é que professor só tem o final de semana livre, então ele não vai ficar estudando, ralando na única folga dele."

Assim, talvez pudesse concluir que os motivos de ausência foram os mais subjetivos possíveis, cada qual com o seu.

Os atrativos, como os apontados pelos professores presentes, não foram suficientes para estimular a participação de todos os inscritos. 
O que seria necessário então para estimular a participação destes professores?

Penso e apresento algumas idéias de situações que pudessem ter mudado o resultado quantitativo do curso.

1) A divulgação e inscrição deste curso realizada pela Diretoria de Ensino de Mogi das Cruzes deveria ser conciliada com uma divulgação feita por mim também, principalmente com uma conversa informal e estimulante junto aos inscritos.

2) A Diretoria de Ensino, apoiando de fato o curso, poderia ter, dispensado no período letivo, dois professores interessados de cada escola, sendo que o total de escolas inscritas foram 16.

3) Eu poderia ter realizado o curso numa unidade escolar, onde meu contato seria diretamente com a direção da escola, facilitando o processo de divulgação e até mesmo de realização com um possível engajamento da direção para isto.

Sobre estas mesmas idéias apresento comentários respectivos que foram decisivos na análise final das ações a serem realizadas.

1) Pensei nesta possibilidade na época, mas, sempre deparava-me com a ausência de recursos financeiros, impedindo varias ações que considerava necessárias, entrando então, nas limitações indesejáveis de uma pesquisa.

2) A Diretoria de Ensino de Mogi das Cruzes recebeu a proposta do curso para os professores e reuniu-se comigo um mês antes da realização do mesmo. Seu posicionamento pode ser conhecido através das falas nesta reunião: 
"Estamos muito interessados neste curso, gostamos muito da proposta, mas, não temos verba para nada, nem para xerox. A única coisa que podemos fazer é ficar responsável pela divulgação e inscrição do curso. Tudo bem?"

"Ah, outra coisa, não é possível fazer em dia de semana, porque tem aula e não dá para dispensar os professores."

Diante de tal situação desinteressante, após argumentações sem sucesso e intransigências, fechei o "negócio", acreditando na importância do grupo e da intervenção como instrumento de transformação, sabendo das dificuldades e riscos que teria pela frente.

3) Minha experiência de quase 10 anos em Mogi das Cruzes, junto a escolas e professores, dava-me segurança para procurar diretamente alguma escola, com garantia de sucesso na realização do curso. Descartei esta possibilidade por considerá-la muito restrita, pensando que o envolvimento da Diretoria de Ensino seria muito mais abrangente e eficiente. Hoje eu agiria e pensaria diferente.

Enfim, sem uma conclusão única da grande ausência dos professores, passamos a valorizar a participação dos presentes, com o grupo interessado em falar deles mesmos:

"Acho que o importante é que nós estamos aqui, e estamos saindo daqui de alma lavada."

"Também acho isto, pois nós agora estamos sabendo das coisas, podemos e queremos participar mais, enquanto os ausentes continuarão ausentes e perdidos." 
"Nosso tempo é complicado, é corrido, mas mesmo assim faremos de tudo para participar, conte com a gente e com nossa escola."

"Valeu a pena ficar o final de semana longe do filho, do marido, este lugar é maravilhoso e aprendemos muito, bem melhor que ficar assistindo Faustão."

Estas observações, que representam de forma geral a opinião do grupo, fazem-me pensar na necessidade da intervenção como forma, não somente de criar e melhorar repertórios, mas também, de estímulo à participação de sujeitos, que ficam esperando o tocar de sinos para despertá-los.

Este grupo demonstrou uma grande sensibilidade em todos os momentos do curso através da exposição de seus sentimentos. De acordo com Barbier (1998, p.181), "entrar no sentimento é poder "soltar-se", é aceitar ser receptivo em relação ao mundo, que sempre nos fala de modo diferente."

Anterior a qualquer apresentação e explicação do curso, foi proposto um exercício solo nos arredores da mata, onde os professores fizessem um mapa de sons, descrevendo seus sentimentos sobre o local e sobre toda a Serra do Itapety.

Isto resultou em 3 horas de leituras e reflexões sobre os mapas individuais, transcritos resumidamente para fichas que expusemos como fotografia sentimental do grupo:

FOTOGRAFIA SENTIMENTAL DO GRUPO

PAZ / TRANQUILIDADE / LIBERDADE / SOLIDÃO GOSTOSA / EQUILÍBRIO/ BELEZA / VIDA / PASSADO X PRESENTE / FELICIDADE / MATURIDADE/ SAUDADE / REFLEXÃO / AMOR / DEUS / RETORNO A ESSÊNCIA

Quadro 4 - Sentimentos dos professores sobre a Serra do Itapety. 
Logo após, pedi a cada um que falasse e escrevesse em fichas algumas palavras chave de características que achavam necessárias no compromissado com o coletivo, dentro de um trabalho de educação ambiental, resultando no quadro abaixo:

\begin{tabular}{|c|}
\hline CARACTERISTICAS NECESSÁRIAS PARA \\
TRABALHAR EDUCAÇÃO AMBIENTAL \\
CONFIANÇA / PERSISTÊNCIA / PACIÊNCIA / SERENIDADE / \\
SENSIBILIDADE / AMOR / RESPEITO / CURIOSIDADE
\end{tabular}

Quadro 5 - Características apontadas como necessárias em educação ambiental.

As explicações de muitos professores para apontar estas características, partiram segundo eles, de intuições, percepções e sentimentos de alegria e contentamento, conforme falas abaixo:

“...Bem, fiquei pensando, pensando, como você não falou nada ainda sobre educação ambiental, procurei analisar o que fizemos até agora, pra ver se tirava disso tudo algo que só pode ser coisa de educação ambiental..."

"Eu fui na mesma direção que ela, até agora tudo que tenho sentido é carinho, amor, paz, então deve estar aí a característica, já que este é um curso de educação ambiental..."

"Para fazer o que vocês fizeram deve ser necessário muita paciência, adorei, é muita sensibilidade." 
Sem exceção, todos professores referiram-se de alguma forma, neste momento, sobre algumas coisas pequenas e simples que havíamos (alunos/estagiários e eu) preparado para eles.

Cada crachá foi personalizado com um desenho infantil feito por nós, em cartolina; durante todo o tempo haviam músicas instrumentais, e com sons da natureza; o café foi organizado e oferecido de forma simpática e calorosa pelos estagiários que ficavam atentos se os professores precisavam de algo.

Talvez isto tenha contribuído para que expusessem tão emocionalmente seus sentimentos e características.

Eles não chegaram preparados para fazer um curso com afetividade, carinho e atenção, reagindo então, neste primeiro momento, com surpresa manifestada em suas emoções.

Barbier (1998, p.179), explica que "ficamos emocionados quando nos defrontamos com uma situação que nos coloca diante do desconhecido e da não-resposta, sendo o fenômeno emocional responsável por acionar as sensações, e também as dimensões cognitivas, imaginativas e intuitivas do ser humano."

Somente após estas atividades é que entrei nas explicações do projeto Agenda 21 da Serra do Itapety, no porque do curso para eles e do seu conteúdo informativo.

\subsection{Professores universitários}

Professores de variadas disciplinas destas duas universidades, puderam expor através de entrevistas, algumas idéias sobre a Serra do Itapety e suas participações em torno da mesma.

Minha atuação com este grupo foi bem tímida, restringindo-se a entrevistas, principalmente pela ausência de recursos financeiros e também pelo tempo limitado para realização desta pesquisa. 
A maioria destes professores reside atualmente em Mogi das Cruzes, devido às facilidades do trabalho próximo, enquanto outros já residem no município há muitos anos ou são naturais daqui.

Todos estes professores já conheciam a Serra do Itapety, pelo menos superficialmente, alguns pessoalmente, alguns através de jornais, outros de ouvir alguém falar, e ainda alguns intensamente apaixonados, como demonstram as falas:

"Nasci ao pé da Serra do Itapety, tenho amor por esta área. Lamento sua degradação, hoje já não existe as coisas que via lá quando criança."

"De onde moro dá para ver a Serra, me faz um bem enorme, mas dá um aperto por saber que minhas filhas talvez não terão o mesmo que eu tive."

"Minha paixão é a Serra do Itapety! Acompanhei o início da devastação desde a década de 80 e isto me entristece, pois ela é o nosso presente."

Mais uma vez, vejo a paixão como estímulo à participação ativa, o que indicou estes mesmos professores, nos trechos abaixo:

"Já fiz várias denúncias de agressões à Serra. Por favor entrem em contato comigo, quero saber dos resultados desta pesquisa e contribuir de alguma forma."

"Parece que os alunos estão mais preocupados com a Serra que nós, professores; deveria ser o contrário, este é o papel da Universidade, precisamos ter iniciativas." 
"Como você sabe, venho trabalhando pela Serra há muito tempo, tento me envolver de várias formas, para tentar garantir sua qualidade."

Sinto, na fala de muitos professores, mesmo os apaixonados, um tom de impotência diante de fatos, deixando-os quase sempre alienados às ações que poderiam desenvolver:

"Tenho muita vontade de conhecer a Serra, acho ela linda, mas, a correria é muito grande, nunca dá tempo."

"Queria muito fazer trabalhos com os alunos no Parque, mas é complicado, os alunos estudam e trabalham e as universidades cumprem muito pouco o seu papel."

"Acho que como professora posso ajudar na conservação da Serra do Itapety e melhoria da qualidade de vida, mas não sei como."

Fazendo uma analogia do discurso destes professores com o discurso ambientalista, é possível relacioná-lo ao que Paulo Freire citado por Viezzer et al (1996, p.125) configura como:

"imobilismo derrotista, existente dentro de duas vertentes de nossa sociedade, pouco acrescentando ao trabalho pedagogicamente crítico: de um lado, a postura doutrinante de uma esquerda autoritária e pessimista e de outro o conservadorismo tecnicista."

Neste caso qualquer um dos lados "inibem a participação cidadã, a participação como uma possibilidade histórica de atuação dos setores populares como protagonistas da história coletiva" (Viezzer et al, 1996, p.124125). 
Então o que fazer com a paixão que poderia ser um estímulo a participação, mas que se inibe diante das palavras e sentimentos derrotistas?

Recorrendo a Espinosa em Chaui, citados por Sacardo (2001, p.148), que discorre sobre as paixões, afirmando ser "o desejo, a alegria e a tristeza afetos originários. O desejo e a alegria podem ser paixão ou ação. Serão paixão quando a causa é imaginária, desconhecida, externa ao desejante, serão ação quando a causa é real, conhecida, interna própria do desejante. Enquanto a tristeza será sempre paixão, jamais será ação. As paixões mais fortes virão sempre da alegria, enquanto as mais fracas vêm da tristeza. Haverá sempre um movimento no sentido das passagens das paixões tristes para as paixões alegres e destas para as ações, nascendo a liberdade suscitada pelo desejo de alegria."

É possível a partir daí, compreender como estes professores apaixonados pela Serra do Itapety mostram-se impotentes diante da problemática existente. Ao mesmo tempo que falam de sua paixão, exprimem também aspectos negativos como justificativas da imobilização, que enfraquecem por demais a paixão, inviabilizando as ações, como eles mesmos apontam.

Acredito ser papel da educação ambiental, buscar formas de contemplar os sentimentos, como as paixões alegres e tristes para que estas últimas sejam "minoradas por outros afetos contrários e mais fortes tramando sempre pelo desejo da vida, fortalecendo as paixões alegres e a participação, na perspectiva de transformações emancipadoras" (Sacardo, 2001, p.148).

Um ponto a ser destacado é a visão dos professores quanto ao papel das universidades mogianas em relação a Serra do Itapety.

Sem exceção todos se referiram à importância fundamental destas para a proteção e conservação da área, mas sem reconhecer/ identificar uma 
atuação nesta direção ou reconhecendo com o apontamento de muitas limitações, como indicam seus comentários:

“... As universidades não fazem nada, apesar de dois cursos de biologia...".

“...As universidades deveriam ter um projeto maior, infelizmente sua visão é muito imediatista, sem grandes investimentos..."

“...Elas deveriam estar mais presentes...”

“...Se é que fazem alguma coisa deveria ser bem maior "

“...Se atuassem, aí teriam um papel fundamental, pena que isto não acontece..."

Por um lado visualizamos estas falas dentro do quadro geral da universidade brasileira discutido por Sorrentino (1995, p.45), ressaltando a "necessidade de reformulações de diretrizes dentro das universidades e também em suas relações com a sociedade para uma contribuição no desenvolvimento de pesquisas destinadas à proteção, recuperação, melhoria do meio ambiente e da qualidade de vida."

Por outro, é necessário destacar que a Universidade Braz Cubas e Universidade de Mogi das Cruzes, discutidas nesta pesquisa, desenvolvem desde 1989 um trabalho inovador, através da criação conjunta de um órgão de pesquisa em conservação da biodiversidade e educação ambiental, o CEMASI, já citado neste trabalho.

A partir da união destas duas universidades, a história ambiental da Serra do Itapety e de todo município de Mogi das Cruzes e região, vem se 
construindo com valores de proteção, preservação, conservação, educação e qualidade de vida.

Com experiências comprovadas cientificamente e popularmente, estas universidades através do CEMASI, conquistaram espaços no mundo acadêmico, científico, político e empresarial que poucas instituições privadas do país alcançaram.

Atualmente o CEMASI desenvolve aproximadamente 20 projetos, financiados pelas próprias universidades e por fontes públicas e privadas, em Mogi das Cruzes, além de municípios do Vale do Paraíba, Vale do Ribeira, interior de São Paulo, e também no Mato Grosso do Sul.

Estes projetos são realizados através de parcerias, convênios, prestação de serviços ou cooperações técnicas com prefeituras municipais, Ibama, Instituto de Botânica de São Paulo, empresas do setor florestal entre outros.

Diante desse quadro, os professores foram questionados sobre o que sabiam das duas universidades em relação a trabalhos na Serra do Itapety, surgindo as seguintes respostas:

"Não tenho conhecimento sobre nenhum trabalho da universidade na Serra."

“...não acompanho os trabalhos feitos pela universidade... ah, não sabia que a universidade trabalhava na Serra..."

"Sei da existência do CEMASI e acho a idéia ótima, mas ainda é pouco, faltam recursos..."

"Não tenho muito contato com o trabalho da universidade."

"Sei que existe o trabalho do CEMASI, mas não é divulgado." 
"Já ouvi falar pelos corredores sobre o CEMASI, até gostaria de saber mais..."

"Existe o CEMASI, mas não sei direito o que é."

"Sim eu conheço os trabalhos do CEMASI, mas não são divulgados e deveriam ser para o bem do próprio trabalho..."

"Conheço o CEMASI e acho que precisam de mais apoio das universidades."

O que pretendo mostrar com estas falas pode ser agrupado em três categorias de professores, todos inseridos nas universidades há mais de três anos:

1) Professores que não estão informados sobre o que sua universidade desenvolve;

2) Professores que possuem uma vaga noção dos trabalhos desenvolvidos; e

3) Professores que conhecem o que é desenvolvido.

A categoria 1, por não ter nenhuma informação, nada opina.

A categoria 2 e 3 convergem para a mesma opinião sobre a ausência de divulgação, apontando isto como uma falha e necessidade para qualidade. Enquanto a categoria 3, possuindo maiores informações, destaca também a necessidade de apoio financeiro e outros, para aumentar e garantir a qualidade do trabalho.

Avaliando o conjunto destas categorias, constata-se a necessidade de trabalhos de educação ambiental junto a estes professores para torná-los participantes de processos internos e externos à universidade, de forma a incluí-los naquilo que os próprios reclamam e percebem ser excluídos, ao mesmo tempo resistindo em participar. 
Como diz Luckesi (1984), queremos uma universidade vinculada à realidade onde está inserida, com todo o corpo universitário comprometido com a reflexão e criação continuada conquistando espaços de liberdade.

\subsection{Vereadores}

Para mim, este foi o melhor grupo da pesquisa, melhor no sentido das surpresas, contentamentos, passando também pelos desgostos encontrados.

Deixei este grupo por último, pelo meu ceticismo em relação à política partidária e institucionalizada de forma geral e também de Mogi das Cruzes, com histórico político ambiental de negligências.

A minha curiosidade e interesse por este grupo foi tornando-se tão grande que passava horas em dias seguidos na Câmara Municipal, sem me dar conta do tempo.

Lá, fui tomando conhecimento de detalhes deste conjunto de senhoras e senhores detentores de poderes sobre a nossa vida, e o melhor, como usam estes poderes.

Iniciei a pesquisa com os vereadores através de entrevistas, considerando esta técnica a melhor opção para acessá-los, julgando que uma outra técnica, que exigisse a reunião de vários deles, fosse inviável por motivos políticos partidários e também pela agenda de cada um.

Em algumas entrevistas e posteriores encontros, comentei que a princípio a idéia era ouvir todos quanto possível numa única reunião, mas a inviabilidade de meu intento confirmou-se quando vereadores manifestaram incompatibilidades tanto de agenda, quanto de idéias e posições, conforme segue:

"...ainda bem que você não fez essa reunião com a gente, seria muito difícil comparecermos, nossos horários são bem diferentes." 
"Nossa! Que bom que foi entrevista, ficamos muito mais à vontade para falar."

"...seria uma briga só, que bom que você repensou."

Encontrei, no conjunto de vereadores, idéias e convicções incoerentes com suas ações, isto reconhecido até mesmo por eles, ao falarem sobre seu papel em uma contribuição à melhora do meio ambiente e o que têm feito para isto:

"Os vereadores têm obrigação de denunciar fatos, cobrar o prefeito, fiscalizar. A minoria dos vereadores contribui."

"Os vereadores devem exigir do poder público, fiscalizar. Se eu falar que os vereadores não contribuem, estarei falando de mim também, mas realmente o envolvimento é pouco, somente o PV é que se preocupa bastante com isto."

"Os vereadores devem aprovar projetos que não desfigurem a Serra, devem se preocupar em conscientizar a população, fazer legislação de preservação. De forma geral, os vereadores não contribuem."

Um discurso de justificativas e isenção de responsabilidades também está presente na fala de alguns vereadores:

"A solução para os problemas da Serra do Itapety está na fiscalização por autoridades competentes do governo do Estado de São Paulo. O Poder público não tem autonomia para fazer quase nada." 
"Devemos estudar mecanismos para complementar as leis, pois a Constituição Federal proíbe os municípios de legislar, então fica difícil fazer alguma coisa."

Destaco agora, os extremos encontrados na atuação de duas mulheres de destaque na Câmara e no município de forma geral. É incrível como tudo nelas, ou pelo menos tudo que pude perceber, polariza-se, das idéias às ações. Vejam os contrastes em suas falas, quando é perguntado o que a Serra do Itapety representa para elas e como os vereadores poderiam contribuir para melhoria de sua qualidade:

Vereadora 1 - “...a Serra é fundamental na história e identidade de Mogi, adoro olhar a Serra de qualquer ponto que esteja, temos que lutar para que ela seja mantida. A Serra é o cartão postal da cidade e deveríamos entender assim"

Vereadora 2 - "Como assim, o que representa? Ah! Não sei. Espera aí. Vereador! Ei Vereador o que a Serra representa? Me ajuda aqui."

Vereadora 1 - "Para começar é preciso ajudar e não atrapalhar, é necessário aprovar o código municipal de meio ambiente, fiscalizar, cumprir leis..."

Vereadora 2 - "Ih! Não sei, o que os outros responderam? Põe a mesma coisa para mim."

Gostaria de mostrar com isto, além da minha indignação pela situação número 2, a necessidade de ocuparmos espaços que já existem para nossa informação, reflexão, observação e constatação, ou seja, a Câmara Municipal é um destes espaços, que deve ser ocupado com esta finalidade principalmente. 
O verificado nesta pesquisa foi uma ocupação significativa na Câmara, mas, para fins de assistencialismo e não de busca emancipatória. Todos os dias dezenas de pessoas comparecem nos gabinetes dos vereadores, pedindo "coisas" como, xerox, compra de remédios, regularização de algum documento, emprego, carta de apresentação e muitas outras coisas.

Comparo esta situação, à cidadania assistida, falada por Demo (2001, p.7), onde o benefício anula a pressão, alertando ainda para seu uso em prol da pobreza política "condição do pobre que vive em estado de ignorância, no sentido da falta de mínima consciência crítica de seus direitos. É literalmente massa de manobra, sem condições de se fazer sujeito de história própria."

Destaco a importância de nossa presença na Câmara Municipal, ouvindo e presenciando as sessões do plenário, o que possibilita o acompanhamento direto na atuação de nossos representantes, podendo a partir daí formar opinião crítica quanto ao desempenho de cada um, com discernimento para uma nova escolha de representação.

Como isto raramente acontece em Mogi das Cruzes, o resultado é um processo inverso de educação ambiental, ocorrendo a desinformação, o assistencialismo, a omissão, enfim, a "pobreza política". Esta por sua vez, fortalece os atos políticos corruptos e demagógicos, enfraquecendo os atos políticos verdadeiros e necessários.

E falando das coisas boas encontradas na Câmara Municipal de Mogi das Cruzes, destacando-se os atos políticos sérios e comprometidos com o povo, contarei o início de uma longa conversa, com vistas a caminhar em direção da emancipação desejada:

Era o meu primeiro contato, com determinada vereadora nesta pesquisa, apresentei-me, juntamente com Alecsandra, como já disse, estagiária que me acompanhou em todas as idas e vindas à Câmara.

Comecei a falar do projeto de mestrado que pretendia entre outras coisas, construir uma Agenda 21 para a Serra do Itapety, com um enorme sorriso ela me interrompeu dizendo: 
"Não acredito, olha as conspirações de energias traduzidas em coincidências, vocês caíram do céu! Por favor quero muito saber sobre tudo da Agenda 21, pois, já há algum tempo em reuniões com meus assessores, temos discutido sobre este assunto, na intenção de fazer algo, através da Câmara, em torno da Agenda 21."

Assim, estivemos durante uma semana todos os dias, no gabinete desta vereadora, em reuniões com a entrega de materiais bibliográficos sobre Agenda 21 e alguns resultados parciais desta pesquisa, objetivando assessorá-la no amadurecimento da sua idéia sobre o envolvimento da Câmara com a Agenda 21.

A eficiência desta vereadora, exemplarmente bem assessorada pelo seu gabinete, possibilitou que em apenas uma semana de nosso trabalho, apresentasse bons resultados, conforme explico a seguir.

Em 21 de agosto de 2001, a vereadora apresentou na Sessão Ordinária da Câmara Municipal de Mogi das Cruzes, um Projeto de Resolução de sua autoria, visando à criação de uma Comissão Especial de Vereadores - CEV com a finalidade de buscar subsídios para a elaboração da Agenda 21 Local do Município.

No dia seguinte, esta Resolução, já aprovada, entrou em vigor, sendo constituída por 05 vereadores, presidida pela vereadora autora do projeto, com prazo de funcionamento de 180 dias, podendo ser renovado se necessário.

Assim, a primeira reunião da CEV - Agenda 21 Local, ocorreu com a minha presença, através de uma apresentação sobre o documento Agenda 21, sobre experiências de elaboração de Agenda 21, incluindo aí a experiência da Serra do Itapety, onde pude detalhar todo seu histórico e metodologia utilizada.

Encerrando esta apresentação, aconteceram algumas reflexões em torno do tema e suas relações, onde determinamos em conjunto, alguns atores que deveriam ser os próximos convidados da CEV. 
Destaco a presença em reuniões seguintes, dos secretários municipais de Planejamento e Urbanismo e da Cultura e Meio Ambiente, onde um deles expõe para os presentes, a existência de um convênio entre a Prefeitura Municipal e a Bio Bras para início da Agenda 21 do município, justificando que nada foi realizado por ausência de recursos financeiros.

Disse também da sua satisfação em ver a CEV fazendo justamente um dos itens do ante projeto apresentado pela Bio Bras, ou seja, envolver os vereadores para participação no processo da Agenda 21, colocando-se em seguida à disposição naquilo que fosse possível.

A CEV pedirá a prorrogação de seu prazo de funcionamento para mais 180 dias propiciando que outras reuniões continuem acontecendo com diferentes atores.

Além das reflexões, discussões e socialização de informações junto aos vereadores, poder executivo e sociedade organizada, a CEV tem cumprido também um importante papel na prática geradora de fiscalização, cobrança e pressão a órgãos do poder público e privado.

Espera-se um resultado, ao final da CEV, em forma de documento endereçado a diversificados órgãos e atores, apresentando os subsídios levantados pelo trabalho e indicação de um caminho construído conjuntamente por todos envolvidos neste processo, para a elaboração da Agenda 21 Local de Mogi das Cruzes. 


\subsection{Os Olhares sobre a Serra do Itapety}

"A porta da verdade estava aberta, mas só deixava passar meia pessoa de cada vez, assim não era possível atingir toda a verdade, porque meia pessoa que entrava só trazia o perfil de meia verdade, e a sua segunda metade, voltava igualmente com meio perfil, e os meios perfis não coincidiam, arrebentaram a porta, derrubaram a porta, chegaram ao lugar luminoso, onde a verdade esplendia seus fogos, era dividida em metades, diferentes uma da outra, chegou-se a discutir qual a metade mais bela, e carecia optar, cada um optou conforme seu capricho, sua ilusão, sua miopia"

(Carlos Drumond de Andrade)

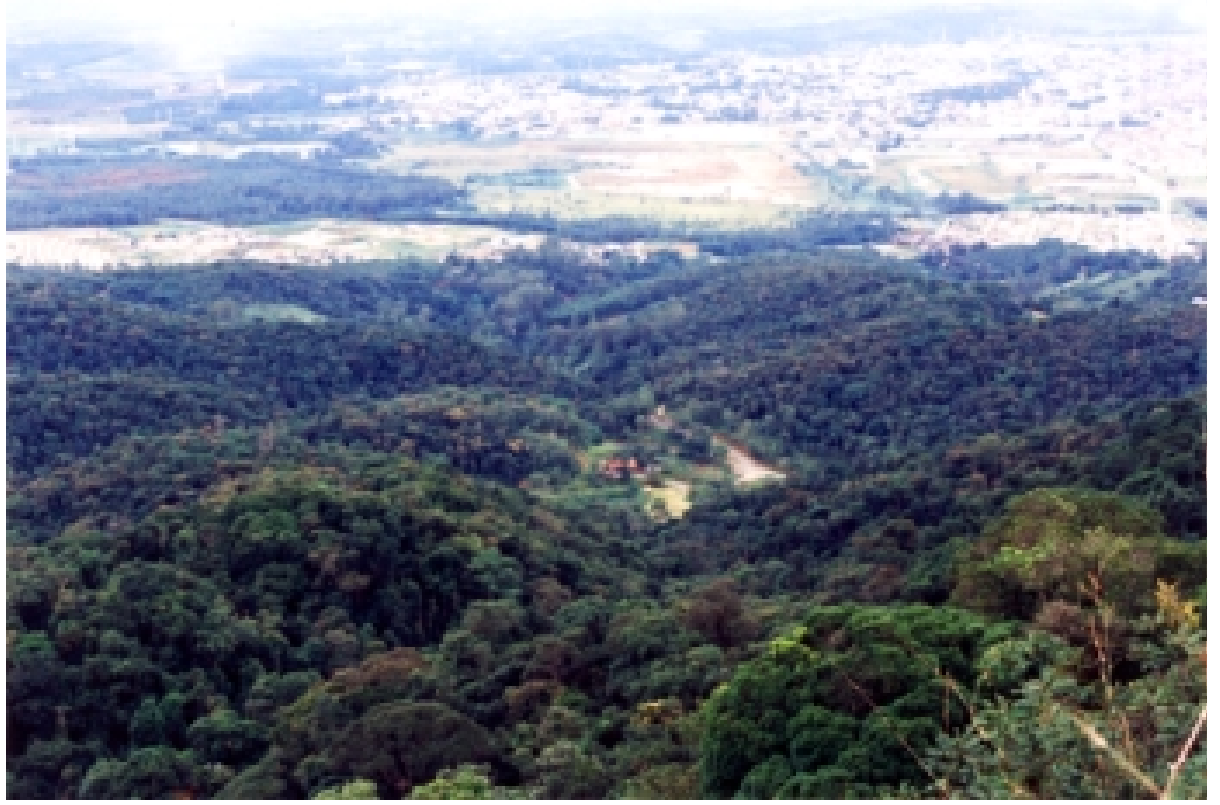

Figura 14 - Vista parcial da Serra do Itapety e área urbana de Mogi das Cruzes.

Fonte: Manna de Deus, 1995. 
Os olhares obtidos através das variadas técnicas desenvolvidas com os distintos grupos desta pesquisa são a base para a construção da Agenda 21 da Serra do Itapety.

Eles representam a fala, o discurso, a percepção, os sentimentos, a visão e as ações de cada um dos grupos envolvidos, cada qual apontando e defendendo sua posição e sua verdade, segundo teorias e práticas científicas, técnicas, políticas, poéticas, acadêmicas, militantes, populares, jurídicas, econômicas, enfim, individuais e coletivas.

Apresento em anexo os olhares de cada grupo, que foram sintetizados para fins de sistematização, sendo possível que cada sujeito participante desta pesquisa se reconheça em seu grupo, pois tudo que foi apontado como problema, solução e sonho está inserido nestas versões.

Após estas versões diversificadas, uma versão unificada dos problemas e soluções foi discutida e refletida durante a reunião que envolveu todos os grupos.

Ficou decidido que "os olhares" dos moradores, por relacionar-se diretamente a resoluções jurídicas pendentes e determinantes no modo de ocupação da Serra, seriam, naquele momento, excluídos das discussões, sendo analisados posteriormente a partir da formação de uma Comissão que tratasse com maior profundidade do assunto.

Devido à restrita divulgação desta reunião para os moradores envolvidos, estes não estavam presentes para expor nenhuma consideração sobre a decisão. Caracterizando-se isto numa falha, com vistas a ser contornada na continuidade desta pesquisa através da Comissão e também através de projetos já delineados, que desenvolverei após o encerramento do presente trabalho.

Alguns itens de forma geral nos Olhares sobre a Serra também foram excluídos pelos grupos, por considerarem impróprios. 
A seguir, a versão unificada dos "Olhares sobre a Serra do Itapety", incluindo apenas os problemas e as sugestões de soluções priorizadas e aceitas pelos presentes na reunião geral.

\subsubsection{Os problemas priorizados}

- Ocupação irregular (com suas conseqüências como: desmatamento, espécies ameaçadas, etc);

- Ausência de recursos financeiros;

- Ausência de fiscalização;

- Descaso das autoridades incluindo omissão contra irregularidades;

- Caçadores e extratores de plantas;

- Isolamento da Serra do Itapety / ilha cercada pelo urbano;

- Ignorância da população e do poder público sobre a importância da Serra do Itapety e sua legislação;

- Legislação deficiente/ lei 4529/85 confusa;

- Ausência de pressão ao poder público por parte da sociedade civil;

- Ausência de divulgação dos trabalhos realizados na Serra do Itapety, do que pode ser feito e do CEMASI;

- Queimadas;

- Especulação imobiliária;

- Pouco conhecimento da biodiversidade existente;

- Universidades mogianas com desempenho deficiente, sem grandes investimentos;

- Incompetência técnica do Poder Executivo na gestão de 1993;

- Ausência de demarcação da área do Parque Natural Municipal;

- Polícia Florestal desorientada;

- Plano de Manejo do Parque Natural Municipal com tímida aplicação;

- Falta de conhecimento técnico ameaçando os trabalhos já existentes para conservação e proteção; 
- Ausência de conhecimento dos vereadores para norteamento de ações;

- Impacto visual negativo;

- Face norte da Serra do Itapety esquecida, tomada por devastações;

- Poucas unidades de conservação na Serra do Itapety/ áreas das unidades existentes muito pequenas;

\subsubsection{As sugestões de soluções priorizadas}

- Revisão do Plano Diretor do município para contemplação da Serra do Itapety;

- Potencialização dos moradores da Serra do Itapety para formação de uma comunidade auto sustentável;

- Inserção de temas sobre meio ambiente específicos do município na educação formal;

- Criação de Secretaria Municipal de Meio Ambiente;

- Criação de um Fundo ou Fundação com programa de proteção ao meio ambiente;

- Compensação ambiental e/ou incentivo fiscal para empresas contribuírem na proteção, pesquisa e educação;

- Aplicação de multas severas aos infratores de leis;

- Ausência de infra-estrutura em locais de invasão;

- Debates sobre meio ambiente;

- Estudos de mecanismos por parte dos vereadores para complementar leis;

- Reprovação de projetos que desfigurem a Serra do Itapety;

- Desapropriação dos moradores irregulares;

- Educação ambiental para moradores, sociedade civil organizada e poder público;

- Mobilização da população para sensibilização e participação na cobrança às autoridades;

- Fiscalização rígida com utilização de meios viáveis como: motos e cavalos; 
- Atuação conjunta de todos os órgãos com parcerias entre poder público e sociedade civil;

- Investimentos de recursos financeiros por parte do setor privado e público, local, estadual, federal e internacional para proteção, pesquisa, educação, segurança e adoção da Serra por empresas privadas;

- Legislação mais clara e severa, com revisão da lei 4529/85 ou elaboração de nova lei;

- Transformação da Serra do Itapety em unidade de conservação - Área de Proteção Ambiental ou aumento da área das unidades existentes;

- Divulgação da Serra do Itapety com os seus problemas, democratização das informações geradas pelas pesquisas e trabalhos realizados pelo CEMASI;

- Potencialização da Serra do Itapety para o desenvolvimento de ecoturismo e turismo de aventura;

- Criação, participação e envolvimento de ONGs. 


\subsubsection{A Comissão da Agenda 21 da Serra do Itapety}

Ao final das discussões sobre a versão unificada dos problemas e soluções, outro resultado surgiu do consenso e reflexão na reunião geral. Foi a criação da Comissão da Agenda 21 da Serra do Itapety, composta por pessoas presentes à reunião, após decisão coletiva de quem dela gostasse e devesse integra-la, com representantes de cada grupo envolvido.

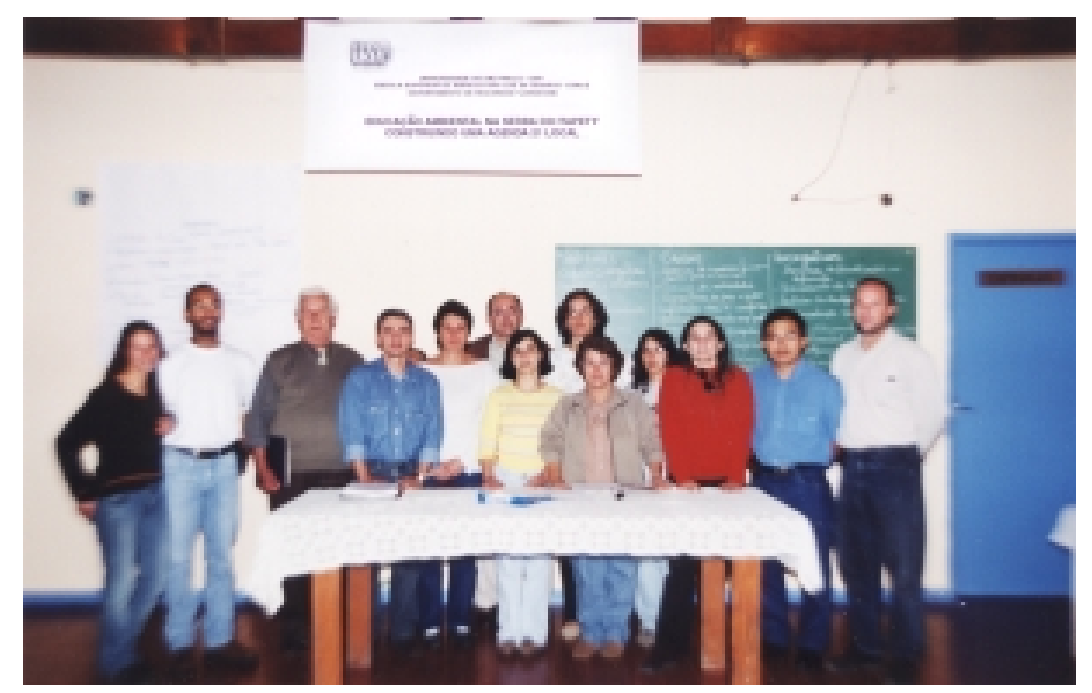

Figura 15 - Alguns integrantes da Comissão.

Com objetivos gerais de sistematização dos olhares unificados em forma de plano de ação e também coordenação da Agenda 21 da Serra do Itapety, esta Comissão iniciou, após sua formação, o desenvolvimento de suas atividades, com a definição dos objetivos e métodos a seguir.

Com as primeiras reuniões um pouco turbulentas, devido a divergências políticas, ideológicas, técnicas e outras, a Comissão passou por momentos de indefinições individuais, que acredito, levaram ao afastamento de alguns sem nenhum tipo de explicação.

Destaco algumas falas destas turbulências:

"...temos que definir muito bem tudo que vamos colocar, pois afinal, o que vamos fazer aqui é um trabalho técnico..." (técnica) 
“...esta sua pesquisa é falha, pois mostra apenas a visão dos moradores do lado horrível da Serra, e não onde eu moro que é maravilhoso..."

(técnica e moradora do entorno da Serra do Itapety)

“...é preciso muito cuidado com o que esta Comissão vai defender, pois temos uma vida fora dela, e não podemos nos comprometer..." (técnica)

Agora apresento algumas falas respostas e explicações sobre as anteriores:

“...a agenda 21 não é técnica, por isso tem os olhares diversos..." (vereadora)

“...claro, se fosse apenas técnica nós não estaríamos aqui..." (professora)

“...é importante que a Agenda contemple as várias visões para que seja de fato um documento resultante da participação da sociedade e do poder público...” (eu)

“...quando nós vamos, participar de qualquer coisa em nossa vida, sabemos o risco que corremos, e temos que assumir uma posição. Assim como tivemos liberdade para entrar nessa Comissão, temos para sair..." (professora)

A manifestação, quanto à visão apenas do "lado horrível" da Serra do Itapety, mencionada pela integrante da Comissão, representa o que esta pesquisa considerou como área de estudo, definida por todos os mapas como Serra do Itapety. 
O lado "maravilhoso" apontado pela mesma integrante da Comissão, não faz parte da Serra do Itapety, localizando-se em seu entorno, considerado nesta pesquisa, mas, de forma secundária.

Posso dizer que estas divergências, após discussões e reflexões, foram minimizadas, talvez porque as pessoas que apresentaram as primeiras falas, estejam ausentes já há várias reuniões.

Esta Comissão, já vem desenvolvendo ações de informação, reflexão e mobilização da sociedade organizada, buscando a garantia da proteção da Serra do Itapety e também de outros interesses sociais.

Dos 17 membros iniciais da Comissão, passamos para 18 por apresentação de grande interesse em participar, e em seguida caímos para 16, devido a 2 funcionários da Prefeitura Municipal terem se desligado da mesma por motivos particulares e consequentemente desligaram-se também do nosso grupo.

Um destes não fez nenhum tipo de comunicado para a Comissão, ausentando-se até hoje, enquanto o outro, colocou-se à disposição para colaborar no que fosse possível, mesmo não integrando mais o grupo.

Temos uma média de apenas 10 membros freqüentando constantemente as reuniões, com alguns não comparecendo em nenhuma até hoje.

Até o momento atual, nós estamos considerando integrantes da Comissão todos aqueles inscritos desde o seu início, mas, devido às ausências constantes de alguns, começamos a pensar em discutir até quando isto é saudável e eficiente no desenvolvimento das atividades.

Desta forma, nosso passo seguinte foi enviar uma correspondência para os integrantes não freqüentadores da Comissão, indagando-os sobre seus motivos de ausências, aguardando respostas e colocando-nos à disposição para uma conversa, no sentido de continuarem participando.

Assim, estamos no aguardo de respostas que possam definir nossas atitudes visando fortalecer o grupo participante da Comissão. 
Em algumas reuniões, temos a presença de pessoas que não integram a Comissão, mas que demonstram desejos de participar informalmente. Estas pessoas têm a liberdade de se expressar, opinar, fazendo assim parte das discussões e decisões da Comissão.

Após as primeiras 3 reuniões, turbulentas, já mencionadas, seguiram até hoje mais 5 , sendo estas realizadas com tranqüilidade e empenho dos integrantes em trabalhar nos objetivos definidos pela Comissão.

As discussões têm ocorrido em torno de cada item dos "Olhares", sem obstáculos pessoais de posição, função, partido, status social ou algum outro que impeça nossas manifestações verbais e até mesmo ações em torno do que nos comprometemos.

Passamos em todas as reuniões por assuntos delicados, que de alguma forma sempre relaciona-se a um de nós da Comissão, algumas vezes pelo cargo ocupado, outras pela ideologia ou filosofia defendida. Independente disso, temos nos dado o direito de discutir, refletir e decidir em conjunto cada detalhe, isto traz resultados que às vezes agrada uns e desagrada outros, mas, é fruto de um esforço coletivo.

\subsubsection{A sistematização dos "Olhares sobre a Serra do Itapety"}

Apresento a seguir os resultados até o momento, do trabalho da Comissão na sistematização dos "Olhares sobre a Serra do Itapety" em forma de plano de ação, constituindo desta forma, a Agenda 21 da Serra do Itapety.

\section{1) Objetivo}

Divulgar de forma ampla e irrestrita os problemas, as qualidades e potencialidades da Serra do Itapety, assim como os trabalhos realizados sobre ela, incluindo as informações geradas pelas pesquisas científicas. 
Metas

- Envolver um público de aproximadamente 100 mil pessoas no prazo de 1 ano;

- Democratizar as informações sobre a Serra do Itapety para todos os interessados.

Ações

1) Promover 3 campanhas anuais de sensibilização e informação junto à população de Mogi das Cruzes;

2) Promover 2 encontros anuais (técnico/acadêmico) para divulgação e debates;

3) Promover anualmente uma feira de exposição de trabalhos populares dos moradores da Serra do Itapety e de outros voltados para a mesma;

4) Publicar artigos científicos e populares em veículos adequados destinados a diferentes públicos;

5) Utilizar de forma ampla a mídia para informação e educação ambiental;

6) Apresentar trabalhos de divulgação nas escolas municipais e estaduais.

Responsáveis pelas ações

1) Prefeitura Municipal de Mogi das Cruzes, UMC, UBC, CEMASI, ONG's;

2) Prefeitura Municipal de Mogi das Cruzes, UMC, UBC, CEMASI, ONG's;

3) Prefeitura Municipal de Mogi das Cruzes, UMC, UBC, CEMASI, ONG's;

4) Prefeitura Municipal de Mogi das Cruzes, UMC, UBC, CEMASI, ONG's;

5) Prefeitura Municipal de Mogi das Cruzes, UMC, UBC, CEMASI, ONG's e Diretoria de Ensino de Mogi das Cruzes;

6) Prefeitura Municipal de Mogi das Cruzes, UMC, UBC, CEMASI, ONG's e Diretoria de Ensino. 


\section{2) Objetivo}

Fiscalizar rigorosamente a Serra do Itapety e seu entorno, evitando os impactos ambientais que provocam sua destruição

Metas

- Aumentar o número de fiscais dos órgãos responsáveis (Prefeitura Municipal, SMA-SP, Polícia Florestal);

- Ter ações de fiscalização diárias;

- Esclarecer e orientar adequadamente os fiscais responsáveis pela ação;

- Extinguir as áreas invadidas e devastadas.

Ações

1) Aplicação de multas severas ao agressor;

2) Encaminhamento de denúncias à Polícia Florestal e Ministério Público;

3) Promover palestras, encontros e cursos de aperfeiçoamento e orientação à Polícia Florestal;

4) Buscar apoio financeiro para o melhor desenvolvimento das atividades da Polícia Florestal;

5) Criar grupo voluntário de fiscais;

6) Utilizar a mídia para denúncias.

Responsáveis pelas ações

1) Prefeitura Municipal de Mogi das Cruzes, SMA-SP, Polícia Florestal e Ministério Público;

2) População em geral, sociedade civil organizada e poder público;

3) UMC, UBC, CEMASI, SMA-SP e Prefeitura Municipal;

4) Polícia Florestal, Prefeitura Municipal e SMA-SP;

5) Prefeitura Municipal, SMA-SP e Polícia Florestal;

6) Todos até agora citados. 


\section{3) Objetivo}

Transformar a Serra do Itapety em Unidade de Conservação Municipal categoria de manejo - APA - Área de Proteção Ambiental.

Metas

- Aumentar quantitativa e qualitativamente a área de preservação e conservação da Serra do Itapety;

- Ter um controle efetivo e seguro da área protegida;

- Garantir a proteção dos recursos naturais e históricos-culturais;

- Obter o reconhecimento e apoio nacional e internacional.

Ações

1) Criar Lei;

2) Revisar Lei 4529/85;

3) Realizar educação ambiental junto aos moradores e demais segmentos da sociedade e poder público;

4) Formar núcleos de educação ambiental e proteção ao longo da Serra do Itapety;

5) Dar apoio ao CEMASI e outros órgãos que queiram realizar trabalhos na Serra do Itapety;

6) Utilizar a mídia para esclarecimentos e divulgação;

7) Reprovar projetos que desfigurem a Serra do Itapety;

8) Impor limites às estruturas arquitetônicas.

Responsáveis pelas ações

1) Prefeitura Municipal de Mogi das Cruzes;

2) SMA-SP, UMC, UBC, CEMASI, ONG's, Ministério Público, Câmara Municipal;

3) Comissão da Agenda 21 da Serra do Itapety, CEMASI, UBC, UMC, ONG's, Prefeitura Municipal e empresas privadas; 
4) Comissão da Agenda 21 da Serra do Itapety, CEMASI, UBC, UMC, ONG's, Prefeitura Municipal e empresas privadas;

5) Prefeitura Municipal, Empresas privadas, SMA-SP e UBC e UMC;

6) Todos os citados até o momento.

7) Câmara Municipal, Prefeitura Municipal, SMA-SP, UBC e UMC;

8) Prefeitura Municipal e SMA-SP.

\section{4) Objetivo}

Criar corredores ecológicos

Metas

- Ampliar as áreas naturais com a possibilidade de conservação da biodiversidade.

Ações

1) Realizar pesquisas;

2) Buscar investimentos.

Responsáveis pelas ações

1) UBC, UMC, CEMASI, Prefeitura Municipal, ONG's;

2) Prefeitura Municipal, SMA-SP, UMC, UBC, CEMASI.

\section{5) Objetivo}

Demarcar a área do Parque Natural Municipal da Serra do Itapety e transformálo em unidade de conservação.

Metas

- Garantir a proteção;

- Coibir as invasões; 
- Potencializar sua área para pesquisa em conservação, preservação e realização de trabalhos educativos e recreativos.

Ações

1) Empenho conjunto dos órgãos responsáveis;

2) Criar decreto de unidade de conservação;

3) Investir recursos financeiros.

Responsáveis pelas ações

1) Prefeitura Municipal, SMA-SP, Emplasa, UMC, UBC e CEMASI;

2) Prefeitura Municipal;

3) Prefeitura Municipal, SMA-SP, empresas privadas.

\section{6) Objetivo}

Potencializar a Serra do Itapety para o desenvolvimento de ecoturismo, turismo de aventura e turismo rural.

Ações

1) Fundamentar o conhecimento técnico/ científico com o poder público;

2) Empenho da Prefeitura Municipal;

3) Realizar um plano de desenvolvimento sustentável.

Responsáveis pelas ações

1) Prefeitura Municipal, Ministério Público, UMC, UBC e CEMASI;

2) Prefeitura Municipal;

3) Prefeitura Municipal, UBC, UMC, CEMASI, ONG's e empresas privadas.

\section{7) Objetivo}

Inserir temas sobre meio ambiente, incluindo os específicos do município e região na educação formal municipal e estadual. 
Meta

- Ampliar a consciência ambiental do município.

Ações

1) Realizar reuniões com Diretoria de Ensino e Prefeitura Municipal;

2) Produzir material didático/ pedagógico de apoio na forma de periódico bimestral;

3) Realizar reuniões com os cursos de Pedagogia do município.

Responsáveis pelas ações

1) Comissão da Agenda 21 da Serra do Itapety e CEMASI;

2) CEMASI, UBC, UMC e empresas privadas;

3) Comissão da Agenda 21 da Serra do Itapety, UBC, UMC e CEMASI.

\section{8) Objetivo}

Construir Parque Urbano em área já destinada para este fim.

Meta

- Propiciar recreação a população de todos os níveis sociais e econômicos

Ações

1) Investir recursos financeiros;

2) Mobilizar a sociedade civil, incluindo a imprensa, para conquista deste espaço;

3) Executar obras.

Responsáveis pelas ações

1) Prefeitura Municipal e empresas privadas;

2) Comissão da Agenda 21 da Serra do Itapety e outros setores da sociedade organizada; 
3) Prefeitura Municipal.

\section{9) Objetivo}

Revisar o Plano Diretor para contemplação da Serra do Itapety.

Meta

- Criar instrumentos legais para proteção e preservação da Serra do Itapety.

Ação

1) Elaborar projeto de lei para proteção integral e sustentável.

Responsáveis pela ação

1) Poder executivo e legislativo

10) Objetivo

Desmembrar a Secretaria Municipal de Cultura e Meio Ambiente.

Metas

- Formar um corpo técnico;

- Ter um orçamento único e maior.

Ação

1) Realizar reunião da comunidade científica com o poder executivo, para esclarecimentos e apresentação de propostas.

Responsáveis pela ação

1) Comissão da Agenda 21 da Serra do Itapety, CEMASI, UBC e UMC. 


\section{1) Objetivo}

Criar Fundo ou Fundação para aplicação de recursos a programas de proteção ao meio ambiente.

Meta

- Investir recursos financeiros provenientes do setor público e privado, local, estadual, federal e internacional em proteção ambiental, pesquisa e educação ambiental.

Ações

1) Adotar o Parque Natural Municipal da Serra do Itapety, visando sua proteção, preservação, conservação e seus trabalhos educativos;

2) Aprovar lei já existente para isto;

3) Mobilizar a sociedade organizada para aprovação da lei.

Responsáveis pelas ações

1) Poder executivo e legislativo;

2) Comissão da Agenda 21 da Serra do Itapety

\section{2) Objetivo}

Desenvolver educação ambiental com a sociedade civil e poder público.

\section{Metas}

- Potencializar os moradores da Serra do Itapety formando comunidade auto sustentável;

- Ter programas de educação ambiental para sociedades sustentáveis e conservação;

- Alcançar o envolvimento e participação do poder público e sociedade civil;

- Ter sociedade civil e poder público unidos em harmonia pela qualidade de vida e do meio ambiente; 
- Fortalecer e emancipar os atores sociais.

Ações

1) Elaborar cartilha sobre a Serra do Itapety aos moradores e outros;

2) Organizar reuniões, oficinas e palestras para orientação e esclarecimento aos moradores sobre a Lei 4529/85 e as qualidades da Serra do Itapety;

3) Aplicar propostas de educação ambiental para sociedades sustentáveis e conservação destinadas aos moradores, poder público, e outros Segmentos da sociedade civil;

4) Investir recursos financeiros em programas de educação ambiental;

5) Realizar trabalhos de militância com os moradores da Serra do Itapety para potencialização da emancipação.

Responsáveis pelas ações

1) Prefeitura Municipal, UMC, UBC, CEMASI e empresas privadas;

2) Comissão da Agenda 21 da Serra do Itapety;

3) Comissão da Agenda 21 da Serra do Itapety, Prefeitura Municipal, UBC, UMC, CEMASI, ONG's e empresas privadas;

4) Prefeitura Municipal, SMA-SP, UBC, UMC e empresas privadas;

5) Comissão da Agenda 21 da Serra do Itapety.

Esta sistematização poderá sofrer algumas alterações após eventos para divulgação deste documento, permitindo através de debates e reflexões, a inclusão de novas sugestões.

A Comissão continuará atuando no cumprimento de seus objetivos, além de incluir-se como responsável por varias ações do Plano de Ação, caracterizando isto na sua continuidade mesmo após o documento - Agenda 21 da Serra do Itapety ser concluído. 


\section{CONSIDERAÇÕES FINAIS}

"Só criaremos espaços de transformação social se, previamente, criarmos espaços de desejo, de afeto entre as pessoas.

O sentido de emancipação, no pensamento pós-moderno, passa pela aquisição do fogo necessário para poder alimentar o desejo de viver: uma capacidade de amar e, ao mesmo tempo, uma competência para poder colocar desejos no mundo.

O amor é um ponto de vista para a constituição não alienada dos objetos de uma cultura. É o ponto de vista da emancipação."

( Luis Alberto Warat)

\subsection{Das manifestações dos grupos à construção da Agenda 21}

Esta pesquisa, construída e reconstruída, à medida que surgiam as oportunidades e obstáculos diante do planejamento previsto, acabou por privilegiar a participação de alguns grupos.

Possibilitou como planejado uma ampla participação dos alunos universitários; de forma inesperada teve o grande envolvimento dos técnicos e vereadores, enquanto os professores universitários tiveram poucas oportunidades neste caminho. 
Quanto aos professores dos ensinos fundamental e médio, a participação ainda que reduzida segundo o previsto no planejamento, pode ser considerada como priorizada nesta pesquisa.

Por motivos diversos de ausência de recursos financeiros e logísticos, foram necessárias algumas reduções nos espaços de participação para os grupos, destacando como inviável apenas a redução para os moradores.

Este grupo não teve até aqui, a oportunidade de refletir, dialogar ou mesmo defender suas posições, por mais que estas se mostrassem incoerentes com as características do local.

Desta forma, a participação deste grupo na construção da Agenda vem sendo discutida, planejada e organizada pela Comissão da Agenda 21 da Serra do Itapety, criada no decorrer desta pesquisa.

Espera-se com isto, a superação das lacunas criadas na participação dos moradores, que de alguma forma deverão inserir-se na Agenda 21 da Serra do Itapety e, desta vez, com as oportunidades necessárias para reflexões que levem às ações.

Assim, sendo a participação dos moradores restringida até o momento, sua ampliação é pretendida, através de propostas de inclusão deste grupo na Agenda 21. Ressaltando novamente que esta pesquisa independente dos vínculos acadêmicos, continuará no caminho do compromisso com a qualidade de vida, principalmente, de grupos minoritários como os moradores e a vida silvestre da Serra do Itapety.

Numa análise geral destes moradores, seguem algumas considerações sobre seus desejos, sonhos, representações, enfim sobre suas idéias, apresentadas ao longo deste trabalho.

Para Espinosa (1989), os corpos sempre são afetados por outros corpos de diversas formas, entendendo-se por corpo aquilo que exprime, que manifesta, sendo esta manifestação originária da essência que é constituída tanto na ordem das idéias como na das coisas. 
Seguindo este pressuposto, analiso a forma que os moradores da Serra do Itapety foram afetados, tendo como base a manifestação destes pelas palavras sobre suas memórias, desejos, representações e sonhos para o local em que vivem.

Percebemos uma boa parte dos moradores afetada pela existência das necessidades não contempladas em seus cotidianos acarretando em insatisfações, em ausência de memória, ausência de saber, ausência de desejos e sonhos.

Espinosa (1989, p.162) diz que "só tem realidade o que é necessário e o que não é necessário, mesmo que seja possível ou provável, é impossível em ato".

Assim, podemos compreender, que as necessidades dos referidos moradores é que os afetam e movem na manifestação da essência que os compõem, apresentando-se com uma realidade de ausências, conforme verificado.

Como tornar parte da realidade aquilo que intimamente não the é necessário?

Porque ter uma memória, um sonho, um desejo, ou manifestar uma representação para a Serra do Itapety, se a realidade encontrada fundamentase em necessidades básicas independentes do local em questão?

Se os moradores tivessem sido afetados pelos valores estéticos, técnicos, ou científicos do lugar, estes seriam manifestados quando chamados pela suas memórias, pois, "se o corpo humano foi uma vez afetado simultaneamente por dois ou vários corpos, sempre que for solicitado recordarse-á imediatamente dos outros" (Espinosa, 1989 p.86).

Ainda no mesmo tratado de Espinosa (1989, p.72), podemos compreender a ausência de idéias, de opiniões ou de desejos dos moradores, visto que "os modos de pensar como o amor, o desejo ou qualquer outro sentimento humano não podem existir num indivíduo se não se verifica neste mesmo indivíduo uma idéia da coisa amada ou desejada" . 
Se quisermos afetar estes moradores pela conservação da Serra do Itapety, antes de mais nada é fundamental que o que Ihes afetam hoje, seja resolvido, no sentido de tornar suas necessidades atendidas e, assim terem uma realidade de satisfação.

Desta forma, teriam como partir para o desejo de outras necessidades transformadas posteriormente em realidade.

A partir da existência da necessidade de conservação da Serra do Itapety para os moradores, seria então possível que estes desenvolvessem em suas essências, como diz Espinosa, uma idéia da coisa desejada ou amada.

Oposto ao espaço reduzido de participação dos Moradores, destaca-se o grande espaço oferecido aos Técnicos, que apresentaram-se com propostas firmadas no conhecimento, na técnica e na racionalidade sobre a problemática da Serra do Itapety e prováveis soluções.

Com oportunidades para reflexões e ações não somente no decorrer desta pesquisa, mas em todo o exercício profissional de cada um, demonstraram priorizar ou considerar apenas os saberes provenientes da lógica técnica instrumental.

Sousa Santos (2000, p.236), em suas análises da cidadania e emancipação, discorre sobre os "pilares" sustentadores para uma transformação da sociedade, são eles:

"pilar da regulação e da emancipação, este último, constituído por três dimensões em articulação - a racionalidade moral-prática do direito moderno; a racionalidade cognitivo-instrumental da ciência e da técnica modernas; e a racionalidade estético-expressiva das artes e da literatura modernas."

Chamando a atenção para a segunda dimensão apontada dentro do pilar da emancipação, podemos visualizar os Técnicos dentro do que é discutido pelo mesmo autor (p.236), dizendo que a "racionalidade cognitivo-instrumental 
desenvolveu-se em detrimento das demais racionalidades, com uma hipertrofia que transformou a própria ciência moderna através da hegemonia das epistemologias positivistas."

Os Técnicos, dotados de grandes conhecimentos sobre todo o contexto da Serra do Itapety, lançam propostas inovadoras, ousadas, capazes de solucionar muitos dos problemas apresentados, mas privam-se de envolvimentos que fujam de suas inteligências racionais, rumo a concretização de suas propostas.

Inseridos na "racionalidade cognitivo-instrumental", acabam por ignorar ou desconsiderar relações que devem estabelecer face a problemática existente, permeando entre outros, o político, o acadêmico e o popular.

Demo (2001), ressalta a necessidade de lembrar que uma decisão técnica, passa também pela política e pelo direito da comunidade em falar e ser ouvida, no caminho do seu convencimento independente da ausência de domínio técnico pela mesma.

No quadro geral, considero os Técnicos dentro de uma lógica racional predominante que configura-se num descompasso com suas qualidades anuladas por uma negação de trocas, tornando assim, crescente a degradação ambiental e social.

"A negação do outro leva à própria negação, enquanto que, a possibilidade do estabelecimento de diálogos interculturais, com toda a sua vivência de complexidade e riqueza, está intimamente ligada ao resgate da história em oposição à história de seu fim, da recuperação das diferenças semânticas que fundamentam o discurso do outro, por meio da troca que constitui o sujeito" (Tassara \& Damergian, 1996 p. 307).

Mesmo com a irracionalidade da lógica racional dos Técnicos, devo considerar o "dever unido a paixão", encontrado em alguns deles, como um 
motivo de suas ações, representando isto uma grande qualidade em seu conjunto.

Os que demonstraram esta característica, embora, seus métodos de ação possam ser da ordem "positivista", agem em sintonia com seus sentimentos mais fortes que os tiram da passividade em busca de melhorias.

Morin (1999, p.20), falando sobre o enfraquecimento ou fortalecimento dos conhecimentos pela afetividade e suas reações, diz que "há estreita relação entre inteligência e afetividade: a faculdade de raciocinar pode ser diminuída ou destruída pelo déficit de emoção."

Chamo a atenção para a necessidade de trabalhos criativos de educação ambiental com técnicos, que se colocam na posição dominadora do saber e poder, numa recusa de entrelaçamentos abertos de articulação com outras classes.

Se o saber e solução do Técnico fossem auto-suficientes e eficazes, a Serra do Itapety não teria sido tão devastada, principalmente nos últimos dez anos, isto visivelmente e comprovado nesta pesquisa. Atentando-se para o fato de, justamente, nos últimos 15 anos entrar em vigor a lei para sua proteção, nestes últimos anos surgirem inúmeras ONG's com fins técnicos de proteção e, também as universidades que se fundamentaram e se estruturaram para realização de trabalhos técnicos.

Com pretensões de transformação social, ambiental e mais especificamente a transformação do diagnóstico sócioambiental da Serra do Itapety, devemos buscar mudanças paradigmáticas, no sentido de mobilização da nossa capacidade de sentir e agir contemplando novas e amplas dimensões.

Refiro-me a construção de uma subjetividade coletiva, firmada em "indivíduos capazes de sentir o que está dentro deles, capazes de autoconhecimento, espécie de sabedoria fundamentada mais no amor que no medo, uma revolução humanista que se contraponha ao status quo" (Tassara \& Damergian 1996, p.310). 
Se muitos dos Técnicos, sentem, pensam e atuam na perspectiva reducionista da "racionalidade cognitivo-instrumental", por outro lado, figuramse os Professores dos Ensinos Fundamental e Médio como frutos desta mesma visão, mas distanciados do compartilhar de tal perspectiva.

Apresentaram-se extremamente receptivos ao novo, ao diálogo, às críticas e reflexões, manifestando sentimentos imanentes de alegria.

Explica-nos Espinosa (1989), que a alegria que pode estar acompanhada de uma causa exterior, por sua vez, propicia a potência de ação, visto que este sentimento representa o lado forte de uma paixão, capaz de nos mover.

O interessante nisto, é saber que nos esforçaremos sempre para manter em nós aquilo que nos dá a atividade, por termos absorvido a essência de tal coisa que nos mantém em movimento, sendo este esforço existente por tempo indefinido, destruído apenas por uma causa exterior (Espinosa, 1989).

A partir daí, destaco o fundamental papel da educação ambiental, como instrumento gerador e mobilizador das forças e potências de sujeitos, num estímulo constante, que facilite a desejada transformação da história de sofrimento individual e coletivo.

A criação de espaços para reflexões, diálogos, trocas sociais e culturais, tornam-se imprescindíveis para a conquista da emancipação, que vem da criticidade, autonomia, consciência e afetividade.

Estes espaços devem ser recheados de estímulos aos sentimentos alegres, que provocam a passagem da passividade para atividade, considerando ainda, que se faz necessário persistir intensamente na idéia e imagem do desejado.

"Quando alguém se contempla e também à sua capacidade de agir, alegra-se. Esta alegria será mais favorecida quanto mais o homem imaginar que é louvado pelos outros, imaginando assim, que os outros são afetados por ele, consequentemente esforçar-se-á por imaginar ainda mais o que Ihe move" (Espinosa p.142). 
Num sentido contrário aos resultados da análise dos Professores dos Ensinos Fundamental e Médio, surgem os Professores Universitários.

Contrário, no que diz respeito aos seus sentimentos imanentes, que manifestaram-se tristes, caracterizando-se então na "potência do padecer que é viver ao acaso dos encontros, pondo nos outros o sentido de minha própria potência de ação" (Sawaia, 2001, p.125).

A paixão como passividade, encontra-se neste grupo com discurso dentro do "imobilismo derrotista", ou seja, ao mesmo tempo que manifestam afetividade pela Serra do Itapety, colocam-se como impotentes para qualquer transformação, configurando-se assim uma paixão triste.

Outro ponto a destacar destes professores, é a forma que se relacionam com a universidade, quando em categorização apresentada no capítulo 3 , encontram-se aqueles distanciados do "fazer" cotidiano universitário, tornandose para eles, incompreensíveis ou irreconhecíveis assuntos e atividades desenvolvidas pelas Universidades há mais de dez anos.

Nesta direção, Sorrentino (2001, p.218-219), nos faz compreender estes professores através do "conceito de participação ligado ao conceito de pertencimento, de sentir-se pertencente, este conceito como oposto ao de alienação, emergindo ainda o da identidade, como capacidade de visualizar, identificar e compreender seu espaço e tempo. Esta compreensão possibilita uma potência no sentido de transformação, uma possibilidade maior de você interferir no seu espaço."

Numa mescla de manifestações, os Alunos Universitários chegaram trazendo características dos Técnicos e Professores dos Ensinos Fundamental e Médio, distanciando-se bastante do discurso impotente dos Professores Universitários.

No início desta pesquisa, estes Alunos, puderam expor e dialogar sobre educação ambiental e a forma que poderiam contribuir para a melhoria da 
qualidade de vida na Serra do Itapety, sendo neste momento conferida a aproximação com as características dos Técnicos.

Mostraram-se inseridos na tradicional "educação bancária" (Freire, 1987), de visão restrita e unidirecional, que faz do educando um cofre para depósitos do "rico e único saber" dos educadores.

De certa forma, isto é coerente e também esperado, visto que os Alunos Universitários vieram deste tipo de educação e cultura carregada de preconceitos, centrados na tradição da racionalidade técnica-cognitiva.

Por outro lado, assim como os Professores dos Ensinos Fundamental e Médio, apresentaram-se dispostos e abertos a participação, cada um movido pela sua subjetividade, pela sua alegria de realizar sua vontade, tornaram realidade aquilo que lhes eram necessário.

Destaca-se neste grupo, uma importante e significativa transformação ocorrida no transcorrer desta pesquisa, com ampliação da visão sobre educação ambiental incluindo o despertar para criticidade necessária em processos de emancipação.

É possível afirmar, que estes Alunos vivenciaram esta pesquisa, numa construção de conhecimentos e participação crítica, criativa e consciente.

Destaco neste momento, a importância da pesquisa com intervenções educativas como um caminho para a conquista do fortalecimento de sujeitos, que se constróem construindo nossa história, desejando espaços políticos, educativos e culturais numa ética humanista.

"As intervenções, enquanto, instâncias de reflexões, são propostas para a desejada recuperação da autonomia, permitindo ainda aos indivíduos, a construção de narrativas de identidade subsidiando a consciência do processo de colonização das alternativas de futuro pelas forças sistemáticas” (Tassara 1998, p. 21). 
Refiro-me agora, ao Vereadores, formados por um conjunto de técnicos, alunos universitários e professores, mas, antes de tudo, políticos.

E como políticos apresentaram-se, receptivos à exposição de suas idéias, destacando-se seus discursos de justificativas que os isentam de responsabilidades.

Ao mesmo tempo, este grupo reconhece e afirma, que dentro de seu papel, pouco ou simplesmente nada fazem para contribuir para a melhoria da qualidade do meio ambiente e consequentemente da qualidade de vida.

Dallari (2001), discursando sobre nosso conhecimento do bem e do mal, do justo e do injusto, diz do uso de nossa inteligência, que cria argumentações, pretextos e desculpas para nossas atitudes reconhecidas por nós como erradas, mas, convenientemente interessantes para nossos interesses.

Chamo atenção, também, para o uso assistencialista da Câmara Municipal, camuflando este espaço significativo para socialização de informações, reflexões e ações, através de benefícios pequenos e individuais.

De acordo com Demo (2001, p.166), este tipo de assistência "pode ser um fantástico engodo, sobretudo quando é usada para alimentar a pobreza política das pessoas excluídas."

É necessário ocuparmos a Câmara Municipal e outros espaços semelhantes, como auxílio em investigações e esclarecimentos para a formação de nossa opinião crítica e consciente, quanto aos atos políticos comprometidos seriamente com a sociedade e os contrários a estes.

Isto pode nos orientar, em direção ao fortalecimento da existente política séria e honesta, que por sua vez enfraquecerá os atos políticos corruptos e demagógicos.

Neste caminho, esta pesquisa gerou bons e inovadores resultados ao encontrar nesta mesma Câmara, políticos honestos e sensibilizados para o engajamento em processos que visam a melhoria da qualidade de vida através da emancipação de sujeitos. 
Passamos nesta pesquisa, por idéias construídas pela restrita racionalidade técnico-cognitivo aos sentimentos diversos, aflorados, anterior e durante este trabalho. Da impotência imobilizadora de sentimentos tristes à potência de ação pelas alegrias, do compromisso assumido e cumprido ao esquecido e ignorado.

Nesta passagem por sentimentos, conhecimentos, reflexões e ações, esta pesquisa, na utopia criada, buscou a integração dos diferentes, num respeito às singularidades de cada um, tentou uma busca pelo outro que acrescentasse individual e coletivamente, sem a anulação de nenhum, mas, pelo sentido emancipatório de todos.

Não sendo possível realizar inteira e satisfatoriamente a utopia criada, acredito ter possibilitado um início de fortes provocações em muitos sujeitos que juntos ou sozinhos darão continuidade a esta utopia e a muitas outras que poderão ser criadas.

"A utopia é a exploração de novas possibilidades e vontades humanas, ela destaca o que não existe como parte integrante do que existe, mas que está silenciada. Ela aponta para o que é radicalmente melhor que a humanidade tem direito de desejar e por que merece lutar" (Sousa Santos 2000 p. 323). 
ANEXOS 


\section{Anexo A - Artigo de jornal sobre o Encontro Técnico Ambiental.}

O DIÁRIO - Mogi das Cruzes, sexta-feira, 16 de Fevereiro de 2001 - CIDADES - 3

\section{Agenda 21 vai proteger a Serra}

$\nabla$ Documento que deve ficar pronto no final do ano poderá evitar novas invasões

erra do Itapeti: $5,2 \mathrm{mil}$ hectares, exuberante flora da Mata Atlântica, 300 moradias irregulares, áreas
desmatadas e alvo de exploradesmatadas e alvo de explorção imobiliária. Para evitar in vasóes e punir infraçōes amnatural de Mogi das Cruzes ganhará até o final do ano a Agenda 21, documento que está sendo claborado pelo Centro de Monitoramento Ambiental da Serra do Itape (Cemasi).

Ontem, representantes do Ministério Público, Prefeitupresas, Organizaçőes NãoGovernamentais (ONGs), universidades e Polícia Floretal se reuniram para definir primeiras açōes conjuntas que podem ser tomadas para garantir a melhor preservação d Serra do Itapeti.

O encontro técnico ambiental é o primeiro de uma sć. rie, que vai entvolver moradonico e alunos universitírios dos ensinos fundatán médio com a proposta de conhecer o ponto de vista de cada un.

Medidas como a intensificação da fiscalização na árc de preservação ambiental $d$ Serra do Itapeti, demarcaçáo da extensao do Parque Natupeti, criacīo de corredores
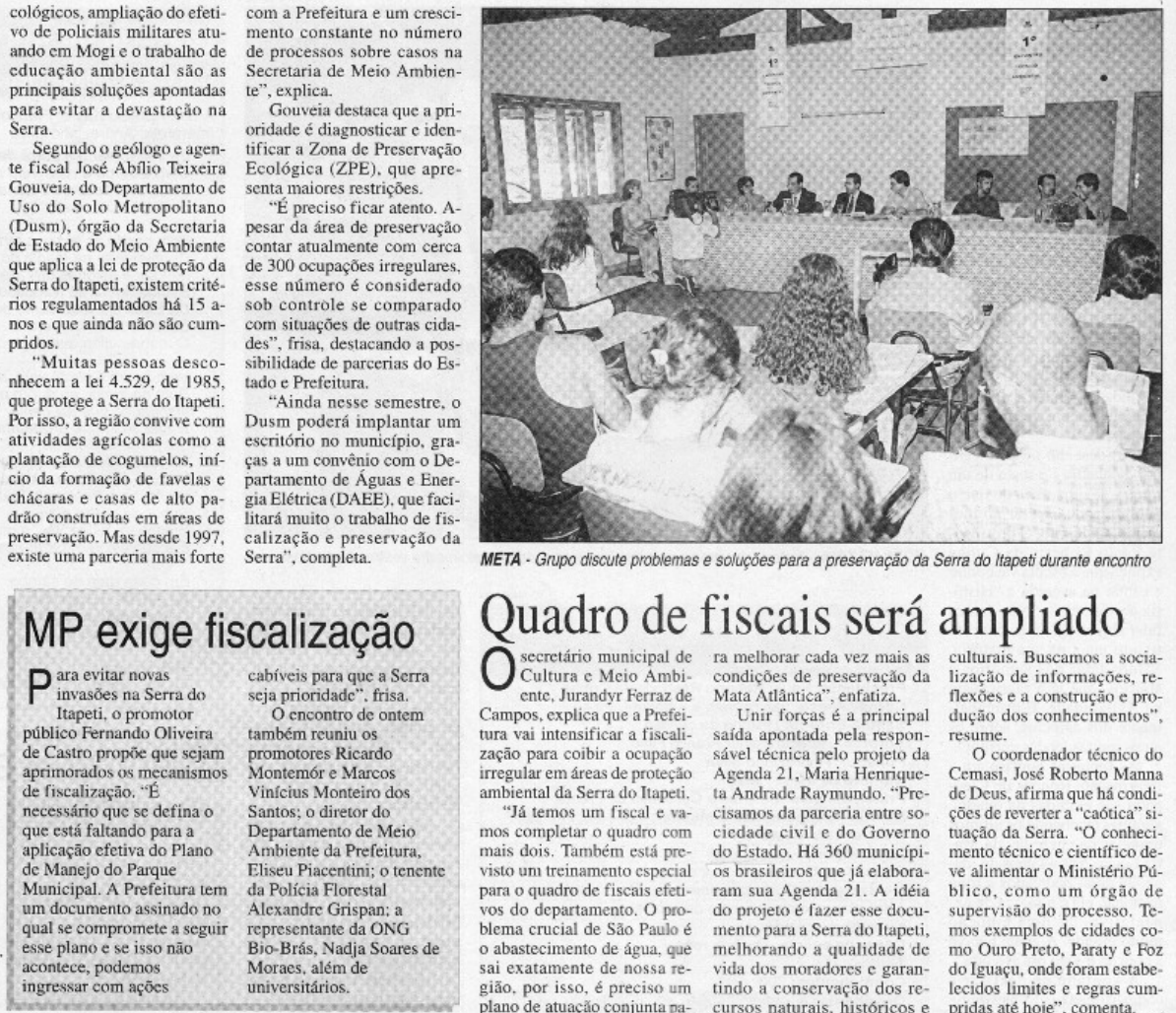

META - Grupo discute problemas e solucōes para a presenvaço da Serra do ltapeti durante encontro Quadro de fiscais será ampliado Secretário municipal de ra melhorar cada vez mais as culturais. Buscamos a sociacntc, Jurandyr Ferraz de Mata Atlântica", enfatiza. Unir forças é a principal dução dos conhecimentos" tura vai intensificar a fiscali- saida apontada pela respon- resume. zaçăo para coibir a ocupaçáo savel tecrnica pelo projeto da O coordenador técnico do irregular em areas de proteçáa Agenda 21, Maria Henrique- Cemasi, Jose Roberto Mann "Í́ temos um fiscal e va- cisamos da parceria entre so- fōes de, . mais dois. Também está pre- do Estado. Há 360 municípi- mento técnico e científico devisto um treinamento especial os brasileiros que ja elabora- ve alimentar o Ministério Púpara o quadro de fiscais efeti- ram sua Agenda 21. A idéia blico, como um órgão de vos do departamento. O pro- do projeto é fazer esse docu- supervisão do processo. Tcblema crucial de São Paulo é mento para a Serra do Itapeti, mos exemplos de cidades coo abastecimento de água, que melhorando a qualidade de mo Ouro Preto. Paraty e Foz sai exatamente de nossa re- vida dos moradores c garan- do Iguaçu, onde foram estabe giấo, por isso, e preciso um tindo a conservaçăo dos re- lecidos limites e regras cum 
Anexo B - Opinião dos alunos universitários sobre a concepção de educação ambiental.

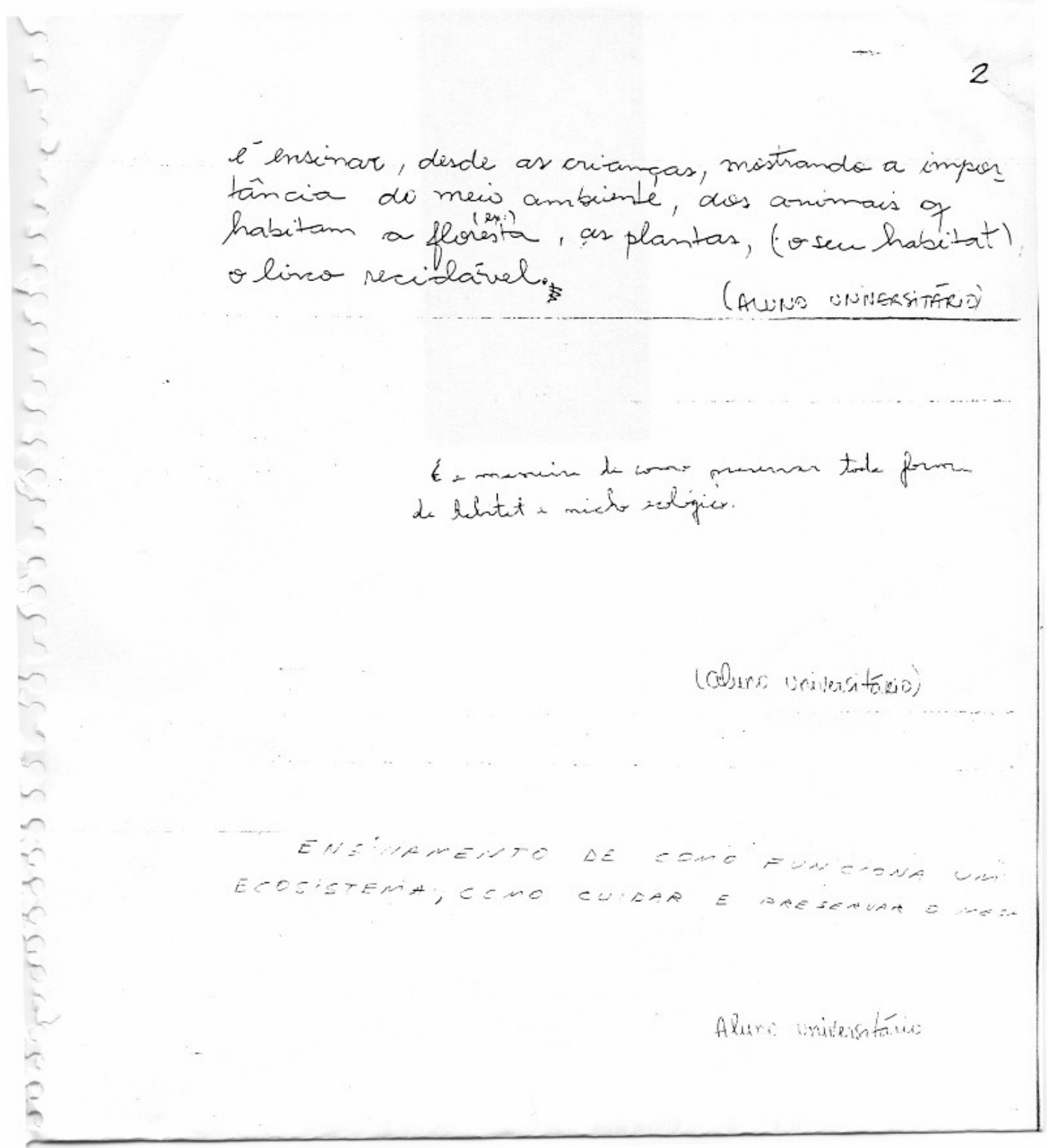




\section{Anexo C - Protocolo de intenções da Prefeitura Municipal de Mogi das Cruzes com a Bio Bras para a construção da Agenda 21 do município.}

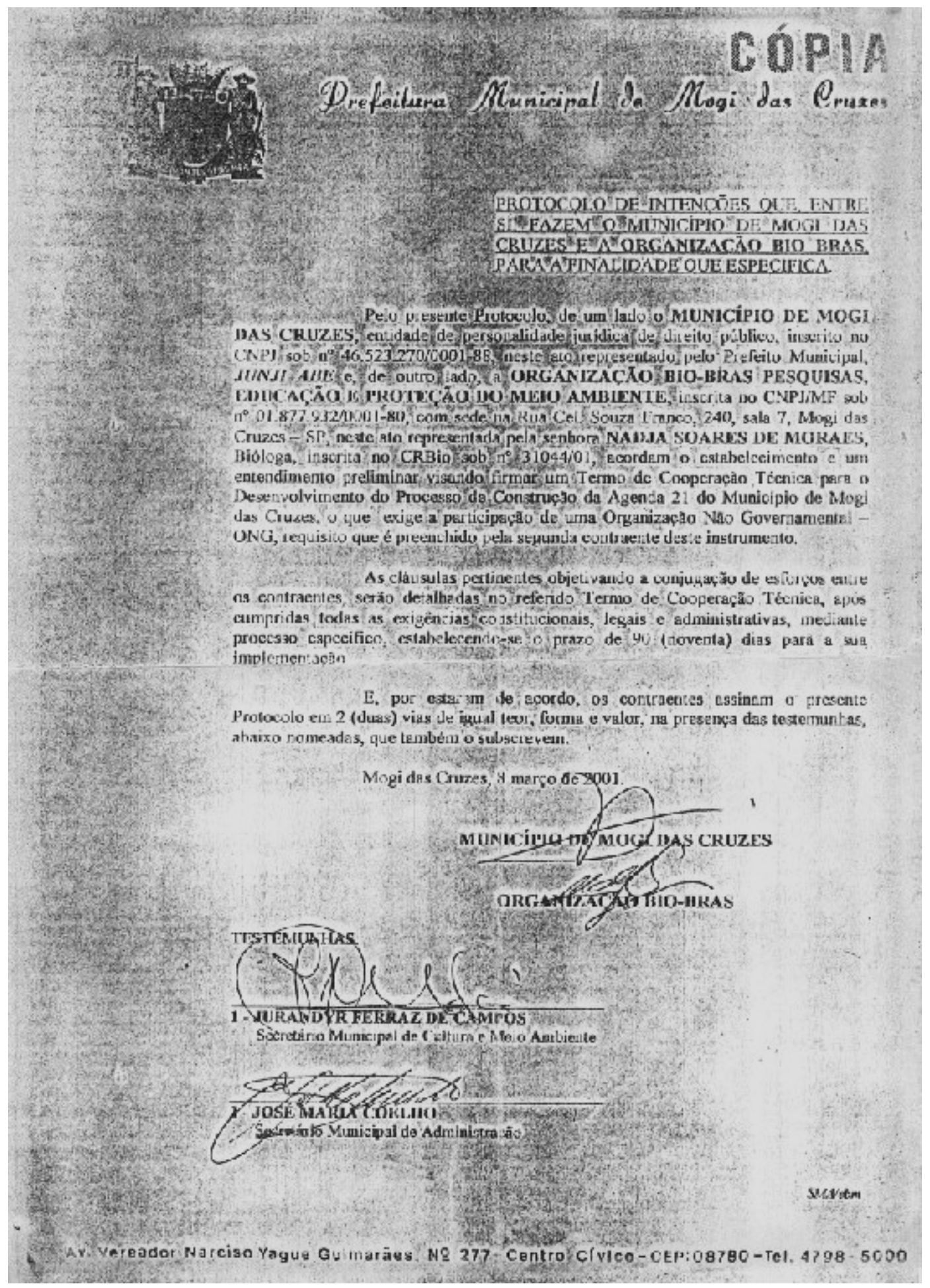




\title{
Anexo D - Ata da sessão na Câmara Municipal para criação da Comissão Especial de Vereadores da Agenda 21 de Mogi das Cruzes.
}

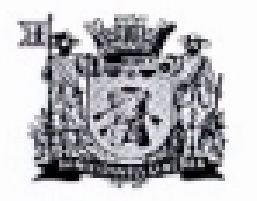

\author{
Camara Allunicipal de fflagi das Cruzes

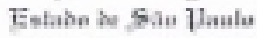

ATA DA SESSİO ORDINARIA DO DIA 21 DE AGOSTO DE 2.001

Consulto o Plenário que se considere objeto de deliberaçẫo o Projeto de Resoluçào de $n^{\circ}$ 013/2001, de autoria da Vereadora Sonia Sampaio, que dispôe de constituiçăo de Comiselo Especial de Vereadores - CEV - Agenda 21 Local e dí outras providências, com a finalidade de buscar subsidios para a elaboraça da Agenda 21 de nossa cidade. Com a palavra a Vereadera Senia Sampaio; senhor Presidente e senhares Vereadores, ea gostaria de explicar o que significa esta CEV, mas primeino dizer o seguinte: alguns dicas atrás cu me pegzei pensando se o masso municipio estaria fazendo ou teria algwme inicialiva no sentido de estar elaborando a nossa Agenda $2 /$ Local, e fuit, atrawis da intemet, buscar algumas iniciativas realizadas en cldades do nosso país e fiquei com aguele material que demonstrova alguns inabalhos jä realizados, quando, para minha surpresa, na semana passada, recebi em minha sala Maria Henriqueta Andrade Raymundo, bubloga, especialisa em educaçẫo ambienal, mestranda em Recursos Florestais pela LASP - ESAIQ. E a Henriqueta me dizia que era objeto de estado de sel mestrado essa quesiäo da "Agenda 21 Local da Serra do liapery", e figuei surpresa como as coisas se canjugam em determinados momeniox. Eil sel que vórios das senhores vereadores foram procurados pela mestranda sobre seu Projeto de mestrado "Educapato Ambiendal na Serra do Hapety - canstrwindo uma Agenda 2f"e comversando com a Henrigueta, cxpes a ela a minha vonsade de estar prowocando essa discussäo ew Mogi dess Cruzes à medida em que nàn exisle pelo menos algwua inicialiva de men conhecimento por parte de nenhuma emidade, seja as Universidades, seja o municipio, atravids da Prefeurura au outros óngalos da cidade e fiquei pensando como a Caimara Mtuicipal poderia dar um passo nessa questâo tão imporiante, inümeras cidades brasileiras já esfão discutindo sua Agenda $2 /$ reunindo centenas de entidades, centenas de pessaas nessa discussồo. Por issa, Senhor Presidente, em discassido com minha assessoria e cow a preipria Nenriqueta, a idéla de fazermos uma CEV, naso para elaburar a Agenda 21 e sim para levamar swhsiallos e encaminhar, sob forma de relateino, postenormene ao Sewhor

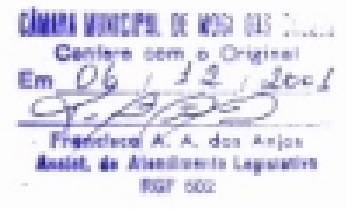




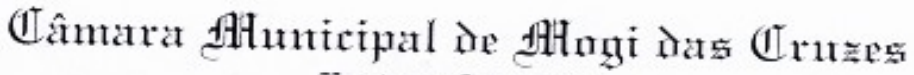

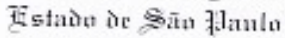

Prefeito, as Universidades, enfim, especialmente ao Poder Público Municipal para que se comece em Mogi a fazermos a nossa Agenda 21 Local. Sabemos que a possibilidade é tão ampla, que, por exemplo, uma escola pode ter sua Agenda, um bairro, a Universidade, ou seja é possivel todos se envolverem nesta tarefa. Em termos de mundo já há um caminho andado, o Brasil já fez e já caminhou na construção da Agenda 21, inclusive o Brasil sediou a Rio-92 a conferência das Nações Unidas sobre o Meio Ambiente e Desenvolvimento Humano e a mais importante reunião da ONU para discutir essa questão. $O$ Brasil assinou o documento se comprometendo a fazer a sua Agenda 21 , em Mogi das Cruzes falta muito para isso se concretizar. O objetivo dessa CEV, e eu gostaria que os vereadores que viessem pra ela tivessem bastante clareza do nosso papel, o papel de estimular o debate, de reunir pessoas e de levantar subsídios para que nós possamos apresentar depois este relatório a quem de direito, entao, Senhor Presidente, só gostaria de justificar essa Comissão e a necessidade de iniciarmos este trabalho para estimular a elaboração da Agenda 21 de nossa cidade. Obrigada. Presidente da Câmara: Não havendo manifestação contrária de Vereador está considerada objeto de deliberação o Projeto de Resolução n ${ }^{\circ}$ 013/2001, encaminha-se para a Secretaria da Casa para fazer constar da pauta da Ordem do Dia da presente sessão.

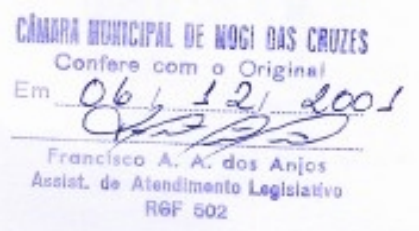




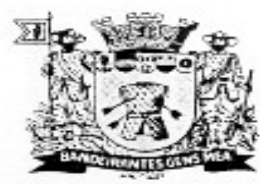

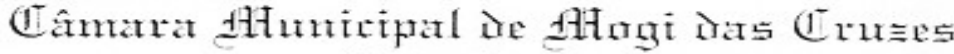

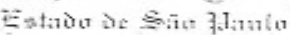

RESOLUCĀO $010 / 01$

(Dispõe sobre constituiçăo de Comissão Especial de Vereadores - CEV - Agenda 21 Local - e dí outras providências).

FACO SABER QUE A CÂMARA APROVOU E EU, NOS TÊRMOS DO INCISO IV DO ARTIGO 66, DA LEI ORGÂNICA DO MUNIĆ́PIO, DE 05 DE ABRIL DE 1.990, PROMULGO A SEGUINTE RESOLUÇ̃̃:

ARTIGO $1^{\circ}$ - Fica criada a Comissão Especial de Vereadores - CEV nos termos do artigo 54, da Resolução $\mathrm{n}^{\circ} 005 / 01$ (Regimento Interno), composta por 05 (cinco) Membros, com a finalidade de buscar subsídios para a elaboração da AGENDA 21 LOCAL de Mogi das Cruzes.

ARTIGO 2" - O prazo de funcionamento da Comissão Especial de que trata o artigo anterior será de 180 (cento e oitenta) dias

ARTIGO $3^{\circ}$ - A Presidència da Cầmara indicará os Vereadores que irāo compor a Comissão de que trata esta Resolução, conforme determina o Regimento Interno (Resoluçāo no 005/01).

ARTIGO 4" - As despesas decorrentes da execução desta Resolução correrāo por conta das dotaçōes próprias consignadas no orçamento da Câmara Municipal.

ARTIGO 5" - Esta Resolução entrará em vigor na data de sua publicação, revogadas as disposições em contrário.

GABINETE DA PRESIDENCLA DACÂMARA MUNICIPAL DE MOGI DAS CRUZES, em 22 de agosto de 200 L $4400^{\circ}$ da Fundação da Cidade de Mogi das Cruzes.

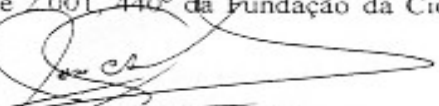

\section{IOSÉA AHORTO CUCO PEREIRA}

SECRETARIA ADMINISTRATIVA DA CÂMARA MUNICIPAL DE MOGI DAS CRUZES, em 22 de agosto de $2.001,440^{\circ}$ da Fundação da Cidade de Mogi das Cruzes. 


\section{Anexo E - Divulgação na internet da comissão especial de vereadores e sua primeira reunião.}

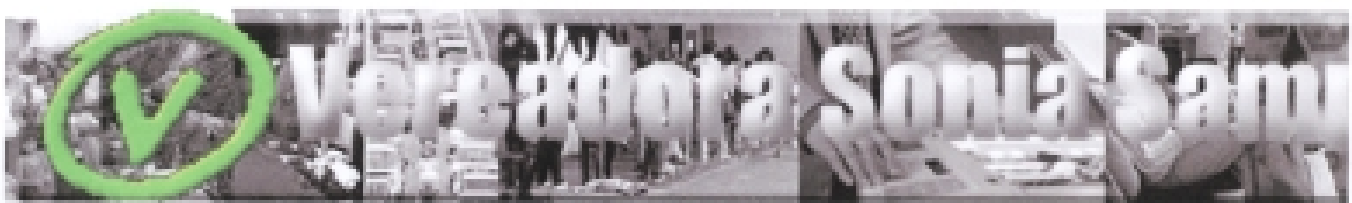

Home I Partido Verde | Asseasoria | Cadantre-se | Mocolen | Contato

Geral

Bartido Verde Noticias

Assesworia

Projetes

Mecbea

Cadastre-se

Contate

Indicesôes

Requerimentes

Link Py

Leis

Lei Organica

Lel do Transporte

Downloads

Begimente Imterno

Voce Sabia

\section{AGENDA 21}

Foi constituida uma Comissão Especial de Vereadores (CEV), Projeto de Resoluçăo đa vereadora SONIA SAMPAIO-PVaprovado na sessāo de 22/08, objetivando buscar subsidios para a elaboraçāo da AGENDA 21 LOCAL de Mogi das Cruzes. Presidida por SONIA, a CEV constituida pelos vereadores Sadao Sakai, Inês Paz, Jolindo Renó e Olimpio Torniyama, deve ter sua primeira reuniāo na próxima quarta-feira (29)tendo como convidada a bióloga Henriqueta Raymundo, para o

A V estabelecimento das diretrizes do trabalho.

As reuniōes da CEV serão abertas acs interessados.

Informe-se das próximas reuniōes no SITE da vereadora ou diretamente em nosso Gabinete (4798-9525 ou 9529). 


\section{Anexo F - Ata da segunda reunião da CEV.}

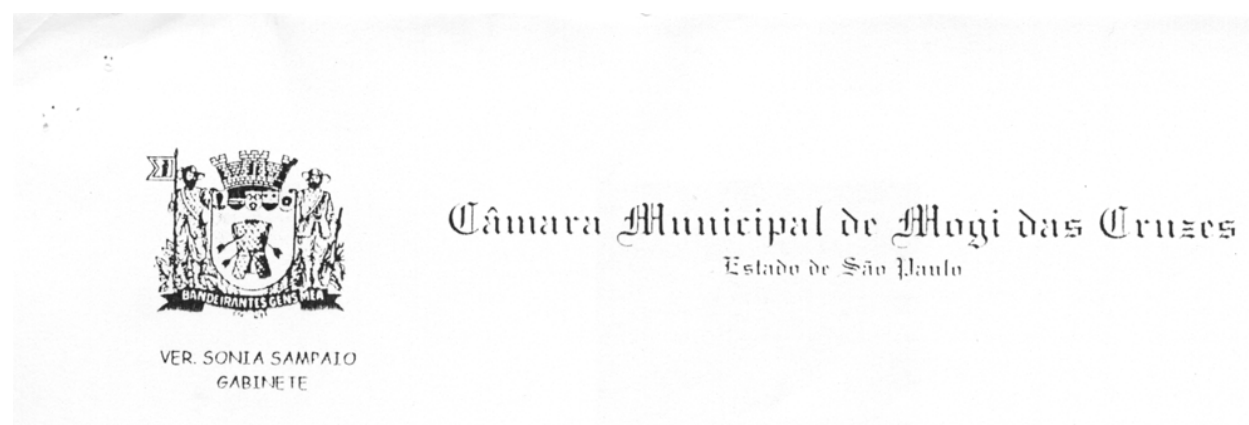

\section{ATA DE REUNIÃO DA CEV - RESOLUÇÃO Nº $010 / 01$}

Ata da Comissão Especial de Vereadores constituida pela Resolução $\mathrm{n}^{\circ}$ 010/01, de 22 de agosto de 2.001, nos termos do Artigo 54 da Resolução $n^{\circ}$ 005/01 (Regimento Interno), com a finalidade de buscar subsidios para elaboração da Agenda 21 Local e nomeada pelo Ato da Presidência $n^{\circ}$ 040/01, de 22 de Agosto de 2.001. No dia 10 de Setembro ano de 2.001, na sala Dr. Sérgio Nogueira, nesta Edilidade, reuniram-se às $10 \mathrm{H} 00$, os vereadores membros da comissão, Sonia Sampaio, Inês Paz, Rinaldo Sadao Sakai, Jolindo Rennó Costa e a bióloga Maria Henriqueta, $1^{\text {a }}$ convidada da CEV e que passa a assessorar a Comissão a convite da presidenta vereadora Sonia Sampaio. Os convidados desta reunião foram os senhores João Francisco Chavedar, Secretário de Planejamento e Urbanismo, e Jurandyr Ferraz Campos, Secretário de Cultura e Meio Ambiente. O Sr. Jurandyr informou que a Prefeitura já havia assinado convênio com a Biobrás para a implantação dos primeiros estudos da Agenda 21, quando da visita do Diretor de Florestas e Biodiversidade do Ministério do Meio Ambiente ao Primeiro Fórum de Desenvolvimento Sustentável do Alto Tietê. Segundo ele, infelizmente, por falta de recursos não havia saido do papel, e que a CEV da Agenda 21 era uma boa oportunidade para sua implementação, colocando-se à disposição naquilo que fosse possivel. Com a palavra o Sr. João Francisco Chavedar, Secretario Municipal de Planejamento e Urbanismo, iniciando, ele cumprimenta a todos e agradece a oportunidade de aprendizagem em conjunto da possibilidade da criação de uma Agenda Municipal e' tentar implantar uma agenda como essa é coisa para dez anos, e estamos iniciando hoje. A questão ambiental é um assunto que veio para ficar e nós já estamos um pouco atrasados, não só pelo Poder Público mas pela própria comunidade acadêmico-ciêntifica, nós poderiamos ter avançado um pouco mais neste assunto. O problema no Brasil é que há um hiato muito grande entre o que se discute academicamente; a classe cientifica tem uma distância muito grande entre o que se vai discutir e se aplicar, aquilo que se ganha de conhecimento e aquilo que vai virar legislação e depois execução. Fico muito grato por estar participando deste assunto, até porque envolve a Secretaria de Planejamento, nós temos diversos instrumentos de intervenção urbanistica no municipio que estão em fase de implantação ou em

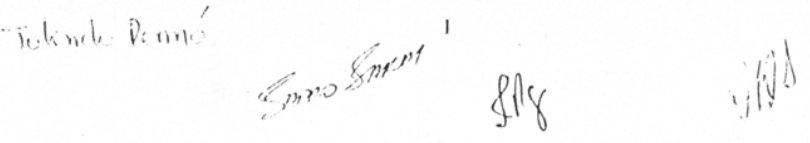




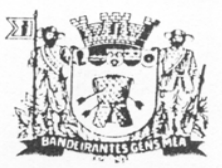

\author{
(T)

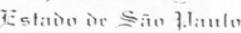

VER. SONIA SAMPAIO

GABINETE fase de serem reestruturados ou elaborados, um deles é a implantação do Plano Diretor. Nós temos hoje um Plano Diretor aprovado, mas longe de ser aplicado; o grande desafio é implementá-lo. Se vamos demorar dois anos para elaborar uma Agenda, temos um prazo de maturação da própria Agenda. Hoje é perigoso implantar completamente o Plano, colocar várias ações do plano diretor e que não pode ter mais volta, tipo: revisão da lei de zoneamento do municipio, sem ter um norte da Agenda 21. Hoje nós não temos uma Agenda 21 que cria possibilidade de desenvolvimento sustentável a nivel de discussão, nem mesmo setorialmente, quem dirá espacialmente. Espaço que temos que criar dentro de uma revisão num plano maior do municipio. A Agenda 21 é de uma certa maneira um grande guarda chuva, pelo menos hoje vejo algumas açöes que estão dentro do guarda chuva, os corredores ecológicos que devem ser incorporados ao Plano Diretor e deve ser urgentemente implantado dentro da revisão da Lei de zoneamento ou mesmo de Legislação de Uso e Ocupação de Solo no municipio. Mesmo que não seja nas áreas urbanas, nós precisamos legislar nos usos adequados, mesmo que seja nas áreas rurais, onde o próprio INCRA pode estar legislando. Outro assunto importante é a criação dos corredores ecológicos, uma série de ações ambientais, que nenhuma legislação nossa, a nivel municipal, conseguimos legislar. A cada legislação de um córrego, ela vê a questão da saúde publica. A Agenda 21 tem que ter um espaço que norteie as discussões sobre uma série de fatores que vão estar envolvidas no Código de Edificaçōes, e o Vereador Jolindo é quem vai ajudar, criar um código de edificações hoje. Sem discutir estas questöes ambientais e estas questōes que estão embutidas dentro da Agenda 21 Local, eu acho prematuro aprovar um Código hoje que possa vir a ser uma algema ao municipio sem uma discussão mais ampla. Então, hoje, nada melhor que estar discutindo a própria Agenda 21 imaginando que ela seja este grande guarda chuva nas discussões destes diversos instrumentos de intervenção urbana que estão intimamente ligados a Secretaria de Planejamento. Finalizando o grande gancho que a Secretaria de Planejamento no Municipio pode ajudar na elaboração da Agenda 21 é a discussão mais ampla do capitulo 07 da Agenda 21 da Eco 92 que fala especificamente sobre assentamentos humanos; a Secretaria do Planejamento estará totalmente aberta e auxiliando no que for possivel. Com a palavra a vereadora Sônia Sampaio diz que era esta a idéia quando foi feito o projeto da Comissão Especial: levantar subsidios para esta discussão da Agenda 21 em Mogi, mesmo sabendo que, não é um trabalho só da Prefeitura ou só da

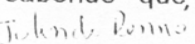
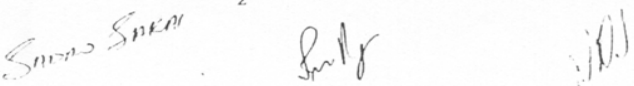


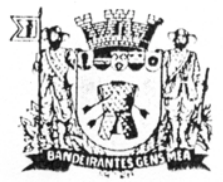

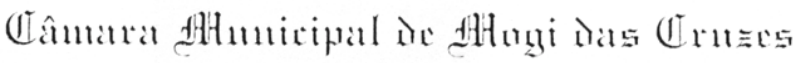

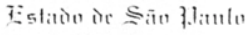

VER. SONIA SAMPAIO

GABINETEniversidade, é preciso envolver toda a cidade nesta questão. Primeiro: um Código ou um Plano Diretor ou uma Agenda 21 têm que ser dinâmicas, o que não pode ser mudado a cada meia hora, então temos que ter tranqüilidade, porque Mogi tem anos de administraçöes que não se preocuparam com estas questöes. Com a palavra o vereador Jolindo Rennó, comenta a respeito da explanação referente à parte ambiental, que è bastante complexa, porque mexe com todo mundo, principalmente com a natureza, e como item principal na comunidade, que é dentro de um processo de planejamento, é o Plano Diretor, que a médio e longo prazo vai nortear o crescimento da cidade; e o Estatuto da Cidade também faz parte do Plano Diretor, e temos que saber no futuro aonde vamos colocá-lo, e a agenda 21 também está integrada neste aspecto. E o mais importante é que são projetos de planos que tem que ter a participação da comunidade. Com relação aos Corredores de Uso Múltiplo, enquanto nós näo temos estes projetos aprovados - veta e depois aprova - eu gostaria que fosse feita uma análise nestes corredores, para ver se realmente aquilo proposto está dentro de uma situação adequada. Num diagnóstico rápido, eu gostaria de fazer algumas colocações a respeito da Secretaria de Cultura e Meio Ambiente, relacionadas à preocupação da Prefeitura com relação aos Corredores Ecológicos. Encaminhamos para Brasilia, ao Ministério do Meio Ambiente, um anteprojeto com levantamento fotográfico da região, mostrando esta viabilidade. Isto com relação a um dos possiveis corredores ecológicos, porque temos outros também, estamos trabalhando com urgência para atender às necessidades fundamentais do planejamento urbanistico de áreas criticas. À medida em que avançarmos com o projeto da Agenda 21, nós não podemos deixar de lado o Código de Fiscalização e Defesa do Meio Ambiente. Antes da Câmara dar entrada no mesmo projeto, o Prefeito já havia nomeado uma Comissão para estarmos estudando a nossa contribuição a nivel da Prefeitura, e discutirmos o projeto através do José Roberto e a Universidade de Mogi das Cruzes. Estão agendando um encontro que seria na semana do dia da árvore, para discutir a questão do Meio Ambiente no Municipio com enfoque na questão do Código de Fiscalização e Defesa do Meio Ambiente. Vereadora Sonia Sampaio afirma a importância da colocação do vereador, em relação ao Código do Meio Ambiente. É importante ser feita uma emenda, e pergunta ao Secretario Chavedar como é feita a implantação do Plano Diretor? E o senhor Secretário, Chavedar, responde que estão em vias de se contratar a Emplasa, que elaborou todo o plano. Para implantação do plano é necessária uma pequena revisão em algumas diretrizes já colocadas. Vamos imaginar um
Il, $, 1, P, 111$,
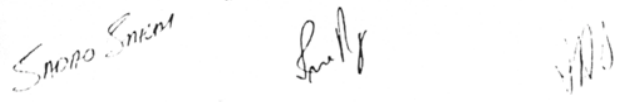


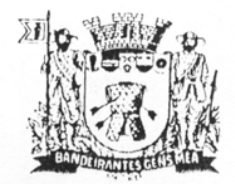

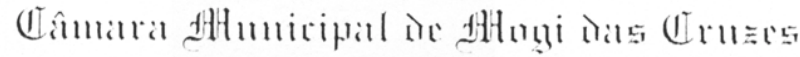

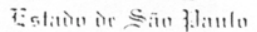

VER. SONIA SAMPAIO

GABINE' F́mapa da cidade visto de um satélite, o Plano Diretor está sempre em cima e separa sempre dois grandes montantes, as ações espaciais e as setoriais; planos de habitaçāo, eu tenho que ter instrumentos para legislar sobre o tema habitação; instrumento para educação; instrumentos para legislar sobre sistema viário do municipio. Se a Secretaria hoje tivesse que implantar o plano, ai ela não faria mais nada nos próximos quatro anos. Então nós precisamos de alguém para nos auxiliar na elaboração de estratégia de implantação das açōes setoriais e espaciais; a Emplasa, na pessoa do sr. Sérgio Zaratin é a mais indicada para nos auxiliar na elaboração, e nós teremos durante oito meses uma sala especifica, aberta para a comunidade inteira que vai criar instrumentos. Quando se fala de implantação, é descer do aviäo e caminhar no plano. Hoje o Plano Diretor de Mogi é a mesma coisa que nada, porque nós ainda estamos em cima do aviäo, não colocamos o pé na realidade, ou seja, nas classes menos favorecidas. Nós temos um Plano, só não conseguimos legislar sobre ele; então, a Prefeitura precisa implementar um Plano. Uma coisa é você legislar pela cidade legal, a outra é entender a cidade real; então, quando há uma mudança de uso em determinadas áreas, é salutar que se crie o zoneamento, o problema é o jeito que a emenda vem para nós, ela não transforma num corredor, ela transforma um corredor num quarteirão, então as respostas dadas são favoráveis, não vamos estar vetando, mas que será objeto de revisão quando tiver a lei de zoneamento. A Agenda 21 não é o Poder Executivo que vai legislar e fiscalizar, e sim a própria comunidade. Mas Código de Defesa do Meio Ambiente passa a ser legislação, e ai é lei, e nós vamos fiscalizar, e não passa da próxima gestão estadual a criação das micros regiōes; não dá para discutir regiăo metropolitana, tão próxima de Guarulhos, quando Guarulhos entra para discutir com milhões de habitantes. Vamos discutir a micro região, e quando se tratar de micro, temos que ter algo para discutir a respeito de meio ambiente. - Com a palavra vereadora Inês Paz, que inicia dizendo sentir uma preocupação mais acentuada agora por causa da escassez dos recursos naturais: o plano apagäo, o uso da água, em outro aspecto näo só Mogi, mas pegando o caso Mogi, ela está sendo organizada por um projeto, e esta administração tem um objetivo. Primeira questão colocada é a seguinte: as modificações, as questões enquanto executivo, que estão vendo, discutindo, em termos de planejamento, meio ambiente, vocês já estão vendo esta mudança para ter uma adequação do plano diretor aprovado, da agenda 21, já esta tendo esta discussão, porque, primeiro: o que eu tenho observado, enquanto parlamentar, quando se discute questäo do meio ambiente em Mogi, alguns
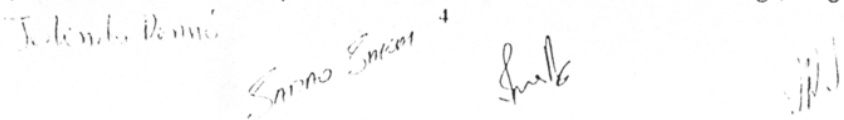


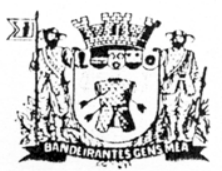

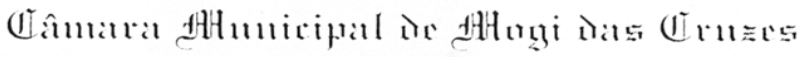
Estation in situ p.liantu

VER. SONIA SAMPAIO

GABINE IE

vereadores antigos dizem assim: o problema é só reposição, a gente mexe aqui e repõe lá, é assim mesmo que temos que enfrentar; segundo, eu ouvi que está sendo feito um desvio do rio Oropó, ele está sendo discutido dentro desta preservação do meio ambiente, dentro do Plano Diretor, ou é bem como acontece aqui na Câmara esta criação do corredor múltiplo, que é para atender um amigo, uma pessoa, está sendo discutido na Secretaria, pegando estas questōes mais amplas; a questão da moradia, toda uma série de leis que vamos fazer, temos que pensar no futuro, mas o que já está existindo, em termos de prioridades, a questão do saneamento básico, como vai se resolver; quanto aos corredores múltiplos, qualquer projeto que venha para a Câmara que mexa com o meio ambiente, as respostas é que repōe em outro lugar, vocês não podem interferir nisto; quanto à audiência publica que tivemos aqui, do Código do Meio Ambiente, tinha um dado que era questão do ser humano, está havendo um deslocamento de gente que está vindo de outras áreas. Nós vamos permitir que haja esta invasão? Que tipo de medida poderia ser tomada? Existe este tipo de preocupação quando vocês discutem?- Com a palavra Secretário Jurandyr diz que nem tudo que envolve a questão do meio ambiente é discutido com a Secretaria, mas quase tudo é discutido, diretamente ou indiretamente. A verdade é que duas Secretarias estão trabalhando muito unidas, a Secretaria de Planejamento e Urbanismo do Chavedar e a minha, mesmo porque estamos quase que diariamente conversando e discutindo, porque todas as questōes que envolvem o Meio Ambiente, são obrigadas a passar pela Secretaria, porque se não tiver o nosso parecer, fica ilegal; amanhã ou depois eles podem estar respondendo por isto. Quanto à questão do córrego, ainda não passou, porque é uma questão que veio da gestão anterior e o córrego foi desviado do leito natural; com relação ao corredor ecológico, como com relação a outros aspectos, mesmo antes de assumir a Secretaria, por causa destas medidas, não foi por conta da crise que se estabeleceu agora, mas muito antes de acontecer esta crise do apagão nós já estávamos preocupados com estas questōes. Quanto à complexidade, é claro que o corredor ecológico é complexo, é como a própria preocupação ambiental, dentro da questão ambiental, é uma questão absolutamente prioritária, ou nós estabelecemos as conexões entre as ilhas de remanescentes florestais, conexão entre elas, e nós estaremos em condiçōes de salvar estes remanescentes da mata atlântica através do salvamento de toda fauna, ou então nós não teremos como salvar estes remanescentes sem salvar a fauna. $E$ se nós não salvarmos a fauna j. limil.: i'cini.

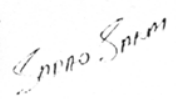

5
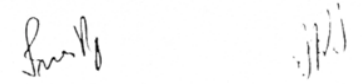


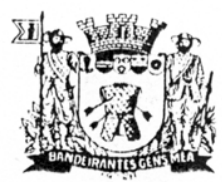

\author{
(T)

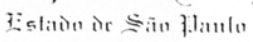

VER. SONIA SAMPAIO

GABINETE

e nem os remanescentes, não teremos água no futuro, é uma questão de absoluta necessidade.- Com a palavra, a Vereadora Sonia Sampaio diz que depois de ter a Ata em mãos, poderá se aprofundar nas questões que a Vereadora Inês colocou. - Com a palavra Secretário Chavedar diz que na medida do possivel a gente tenta sentar com todos os secretários na definição de uma proposta de um planejamento mais estratégico. Sem a implantação do Plano, fica dificil de ter instrumentos para argumentar tecnicamente com os secretários; o meu equacionamento é técnico e não político, sempre justificando e passando para as pessoas de direito. A posição técnica, sem estar em desacordo com a Secretaria de Planejamento, tudo que passou pela secretaria com envolvimento de diversos secretários, sempre foi naquele momento a posição técnica mais acertada. Dentro de uma visão política, com relação aos corredores, já tivemos uma conversa informal entre mim, o Prefeito, o Vereador Jolindo e o Presidente da Câmara Cuco Pereira, onde estamos tentando, com a ajuda dos Vereadores, arrumar uma maneira de fazer com que a ansiedade de diversos vereadores seja um pouco freada nas questões da criação dos corredores. E uma saida politica que achamos é a vinda de alguns diretores da área de Uso e Ocupação do Solo, Irineu, Humberto e outros, e os próprios Secretários, e fazer uma explanação explicando o porquê da não colocação e, se for necessária a criação de um corredor ou atividade que a própria Secretaria de Planejamento fosse ouvida no auxilio da elaboração de um Projeto de Lei como este. Não adianta ficar esperando por nós, porque vamos demorar um pouco; se precisa criar um corredor na José Glicéreo de Melo, então vai uma equipe inteira de projeto naquela área, vamos fazer uma analise urbanistica inteira, e pegar todas as atividades que possam ser colocadas, incluindo aquela que é o ensejo do vereador, mas vamos criar toda uma sistemática, uma metodologia para poder analisar este corredor com a própria parceria da Secretaria de Planejamento, junto com Associação do Engenheiros e Arquitetos, IAB, Universidades. Dependendo da complexidade do projeto, como este é o primeiro ano e é de muita ansiedade, e de alguma maneira a Secretaria de Planejamento está conseguindo colocar os seus projetos, que na verdade não são projetos para mostrar para o publico, a Secretaria de Planejamento nunca existiu, e frutos desta Secretaria só serão colhidos daqui a uns seis, sete, oito anos. Vamos fazer força para que a própria Câmara aprove isto, nesta gestão a gente aprove o Conselho Municipal de Planejamento, onde as ações de planejamento serão discutidas no âmbito da cidade com a participação popular. A criação do Conselho Municipal, sendo o primeiro passo para criação do IPUC Mogi, com relação à costura politica, acho que não sou a pessoa mais capacitada para discutir o melhor encaminhamento. - Com a palavra vereador Sadao Sakai, que cumprimenta os Secretários pela presença e explana a respeito das questões em referência, e que se Tolimu limm,
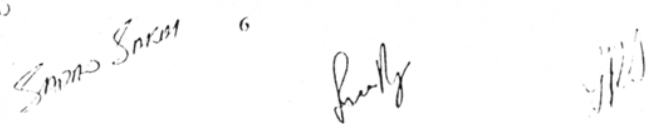


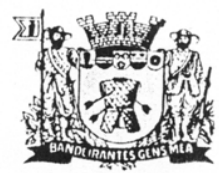

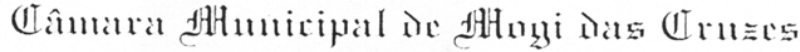

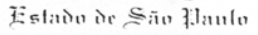

VER. SONIA SAMPAIO

GABINETFosse para tratar do assunto de assentamento humano demoraria uma semana, porque da forma desorganizada que está sendo efetuada no municipio, a gente vê que é uma questão até criminosa, sem fiscalização nenhuma, e que para inicio esta reunião está sendo bastante proveitosa. Eu pretendo frequentar mais a Secretaria para realmente discutir todas as questões ambientais de planejamento, porque Mogi das Cruzes na questão de meio ambiente, está bastante abandonada. - Agradecendo a oportunidade, Secretário Chavedar diz que Agenda 21 só vai ser bem feita se costurarmos isto e se for de uma maneira muito bem feita, e na verdade como ela é um guarda chuva, nós não vamos conseguir conclui-la se nos próximos noventa dias não conseguirmos ter os conceitos de elaboração da Agenda muito bem definida. Nós não vamos perder o fio da meada dos outros instrumentos se dentro de um prazo curto conseguirmos definir o conceito, a coluna central da Agenda. Nós temos como desenvolver outros instrumentos, e a Prefeitura continua sendo a menor parte. A Secretaria não faz nada sem transparência junto à classe técnica, nem o desenho de praça e nem projeto. Ela não faz projeto, ela é a caneta, é o instrumento; quem faz são os arquitetos convidados, a classe artística, são estas pessoas que fazem. A Agenda 21 continua, o Executivo e o Legislativo sendo instrumentos para elaboração de um projeto como este, a comunidade precisa ser ouvida, não pode ter um pacote e sim um processo de construção. vereadora Sonia Sampaio diz que as questōes levantadas nos fazem debruçar sobre a metodologia. E que os pontos levantados da primeira reunião: que entidades, que forças vivas vamos chamar para abrir o leque, porque considero os vereadores e as secretarias como instrumentos da população. Passando a palavra ao senhor Jurandyr que agradece a oportunidade valiosa e complementando a colocação do Vereador Sadao, que neste ante projeto da Maria Henriqueta, no item 10 , formação de grupo de trabalho, poderia servir como roteiro para o início da preocupação conceitual, com ampla participação da comunidade organizada e articulada servirão de apoio ao Fórum Ambiental, então o caminho é exatamente este. A questão ambiental do municipio é bastante complexa, nós temos oportunidade de estar abrindo o leque dos projetos para que os vereadores tenham uma informação mais correta, e grande parte destes problemas nós herdamos do passado e estamos preocupados. Uma das primeiras colocações do Prefeito é no sentido de estarmos congelando estas preocupações dentro do possivel e temos contado também com a comunidade através de denúncias, todas as denúncias, seja qual for a região, nós estamos atento. $E$ concluindo, a complexidade, temos o problema da agricultura, um -Julinde Remní
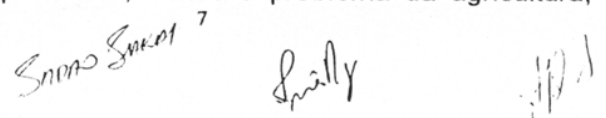


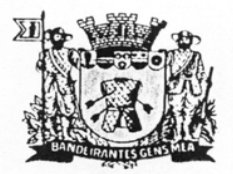

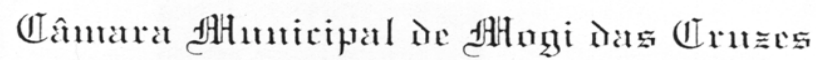 \\ Estutu ite Siñ jilutu
}

VER. SONIA SAMPAIO

GABINETE dos grandes responsáveis de despejos de metais no Tietê vem da agricultura, e a Agenda 21 é o único caminho que temos para num conjunto estarmos contemplando no sentido de realmente termos um desenvolvimento sustentável, válido e que as nossa comunidade possa estar confiando no Poder Publico, Executivo e Legislativo. Vereadora Sonia Sampaio diz já conhecer o projeto que o Secretário tem em mãos do CEMASI e, em nome da Comissão, agradeçe a presença de todos os Vereadores, dos Secretários, funcionários, e que temos um longo caminho, e a partir da reunião de hoje, as observações que aqui foram feitas, vamos ser capazes de formular este subsidios que queremos para elaborar a Agenda 21 em Mogi das Cruzes e todos seräo avisados da próxima reunião. Esta reunião teve seu término as $12 \mathrm{~h} 05$ do mesmo dia, e esta Ata vai assinada pelos membros participantes desta reunião de instalação.

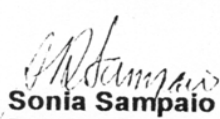

Sonia Sampaio

Presidente da CEV

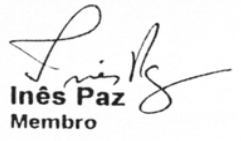

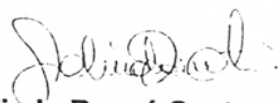

Jolindo Rennó Costa

Membro

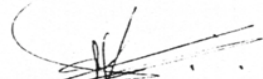

Rinaldo Sadao Sakai

$$
\text { curente }
$$

Olímpio Osamu Tomiyama

Membro 


\section{Anexo G - Os olhares sobre a Serra do Itapety de cada grupo da pesquisa.}

\section{TÉCNICOS}

\begin{tabular}{|c|c|c|}
\hline PROBLEMAS & SOLUÇÖES & SONHOS/DESEJOS \\
\hline 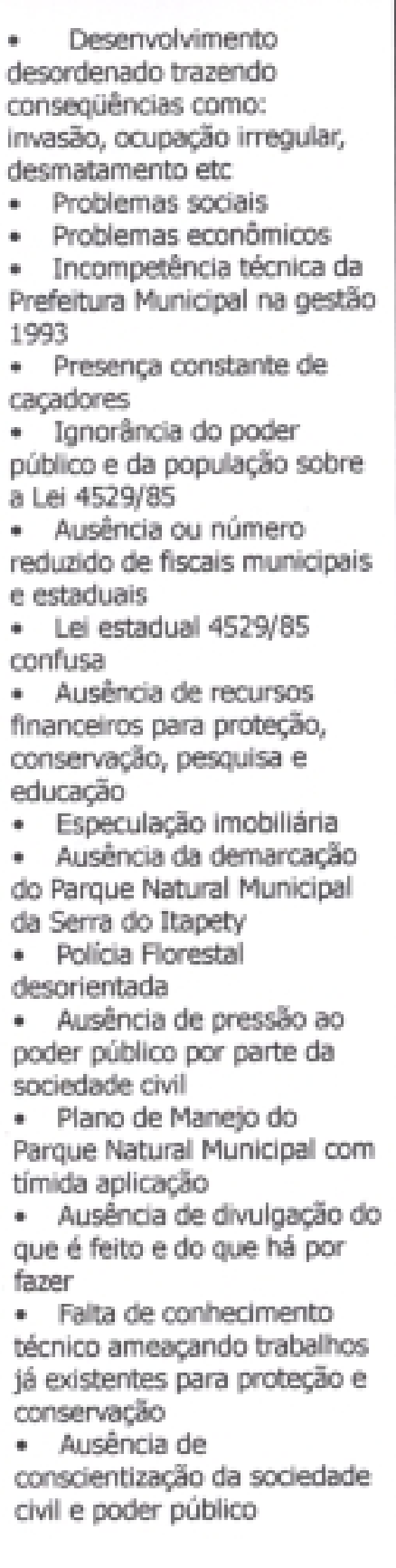 & 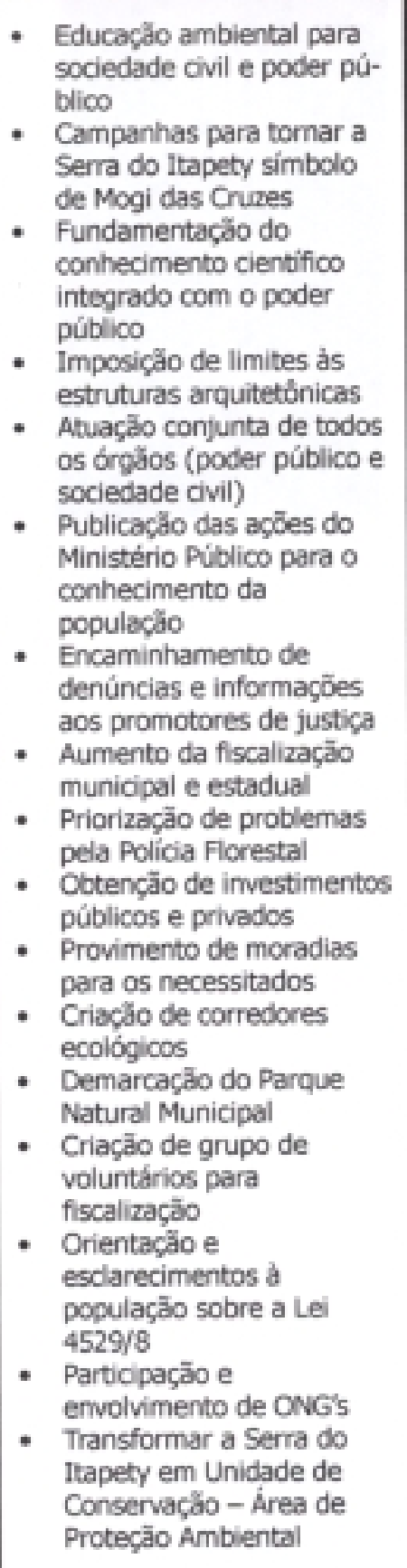 & $\begin{array}{l}\text { - Preservaçäo total } \\
\text { - Investimentos sociais } \\
\text { Conscientizaçäo geral da } \\
\text { importăncia da } \\
\text { preservação e } \\
\text { conservação } \\
\text { - Que a Serra do Itapety } \\
\text { seja um referencial da } \\
\text { preservaçăo ambiental } \\
\text { - Que haja educaçäo, } \\
\text { fiscalizaçăo e divulgação } \\
\text { - Educação ambiental para } \\
\text { cidadania }\end{array}$ \\
\hline
\end{tabular}




\begin{tabular}{|c|c|c|}
\hline PROBLEMAS & SOLUÇÖES & SONHOS/DESEJOS \\
\hline & 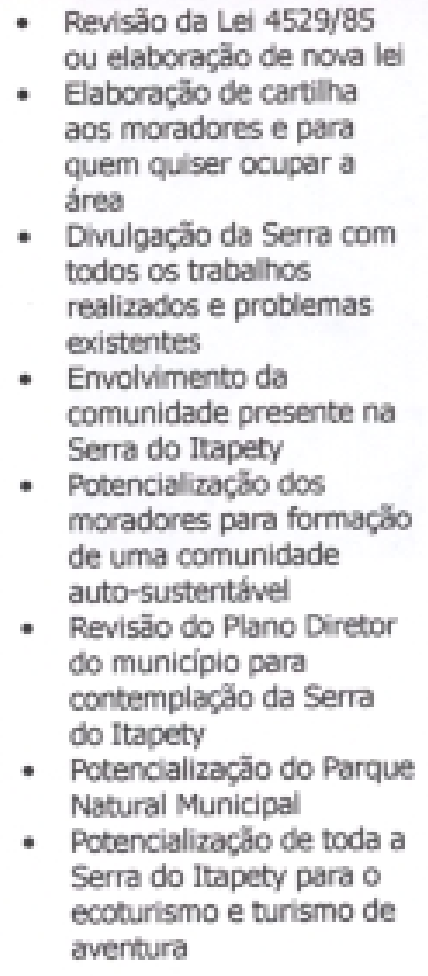 & \\
\hline
\end{tabular}




\section{ALUNOS UNIVERSITÁRIOS}

\begin{tabular}{|c|c|c|}
\hline PROBLEMAS & SOLUÇÕES & SONHOS/DESEJOS \\
\hline $\begin{array}{l}\text { - Descaso das } \\
\text { autoridades } \\
\text { - Expansäo urbana } \\
\text { desordenada, com várias } \\
\text { interferências antrópicas } \\
\text { - Ausência de recursos } \\
\text { financeiros para proteçä́, } \\
\text { educação e fiscalizaçäo } \\
\text { - Ausência de fiscalizaçäo } \\
\text { - Ausência de } \\
\text { conscientização } \\
\text { - Isolamento da Serra do } \\
\text { Itapety, colocando em risco a } \\
\text { biodiversidade } \\
\text { - Poucas unidade de } \\
\text { conservaçäo na Serra do } \\
\text { Itapety } \\
\text { - Legislaç̃o deficiente } \\
\text { - Valores humanos } \\
\text { deficientes como: falta de } \\
\text { respeito ao próximo, } \\
\text { solidariedade, sensibilidade e } \\
\text { etc. }\end{array}$ & $\begin{array}{l}\text { - Transformar toda a } \\
\text { Serra do Itapety em unidade } \\
\text { de conservaçdo } \\
\text { - Educaçäo ambiental } \\
\text { para sociedade civil e poder } \\
\text { público } \\
\text { - Desapropriação das } \\
\text { propriedades irregulares } \\
\text { - Investimentos do } \\
\text { governo municipal para } \\
\text { proteçäo, pesquisa, } \\
\text { educaçăo e segurança } \\
\text { - Pesquisas para novas } \\
\text { descobertas } \\
\text { - Fechamento do Parque } \\
\text { Natural Municipal } \\
\text { - Construçăo de parque } \\
\text { urbano na cidade } \\
\text { - Obtençäo de apoio da } \\
\text { iniciativa privada para } \\
\text { investimentos na proteçäo, } \\
\text { pesquisa e educação }\end{array}$ & 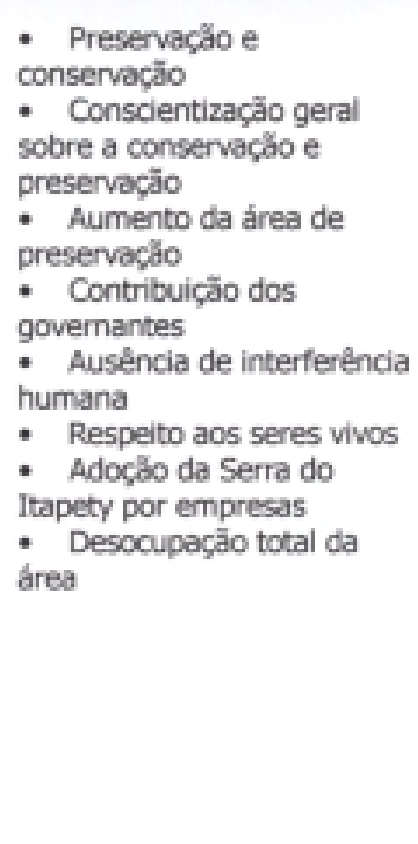 \\
\hline
\end{tabular}




\section{MORADORES}

\begin{tabular}{|c|c|c|}
\hline PROBLEMAS & SOLUÇÕES & SONHOS/DESEJOS \\
\hline 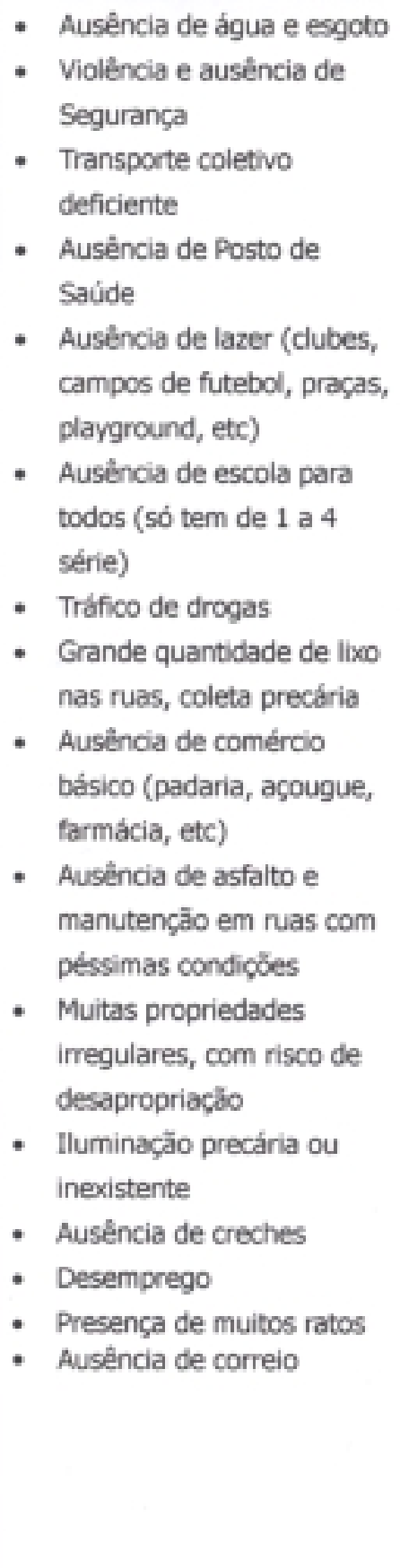 & 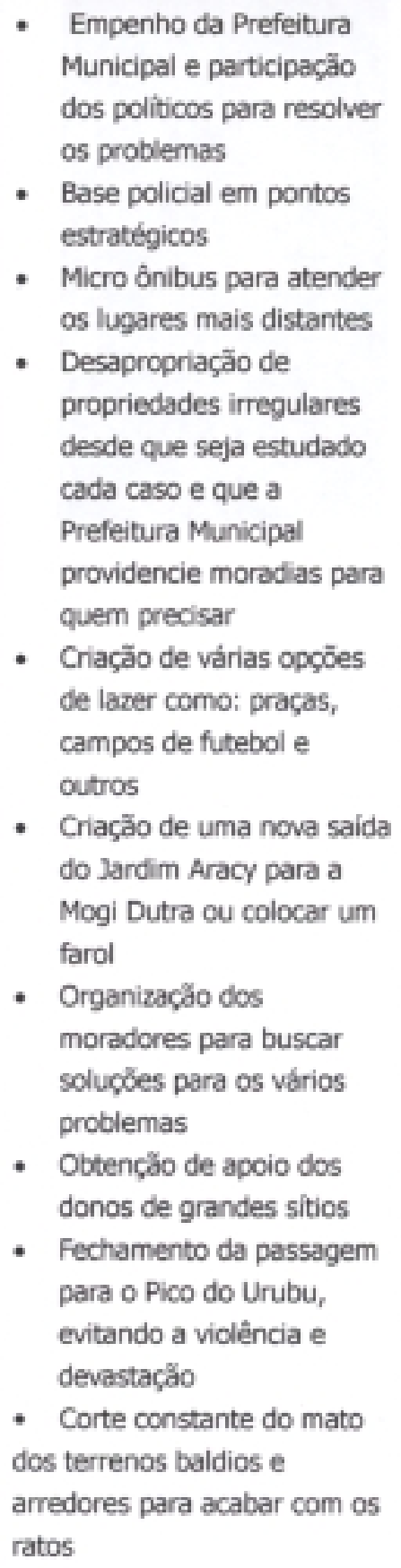 & $\begin{array}{l}\text { - Ver a preservação e } \\
\text { conservação do local } \\
\text { - Parque Natural } \\
\text { Municipal reaberto para } \\
\text { lazer } \\
\text { - Ter segurança } \\
\text { - Ter área de lazer } \\
\text { - Legalização das } \\
\text { propriedades } \\
\text { - Ir embora deste lugar } \\
\text { - Ter emprego }\end{array}$ \\
\hline
\end{tabular}


PROFESSORES DOS ENSINOS FUNDAMENTAL E MÉDIO

\begin{tabular}{|c|c|c|}
\hline PROBLEMAS & SOLUÇÕES & SONHOS/DESEJOS \\
\hline $\begin{array}{l}\text { - Descaso das autoridades } \\
\text { en nivel municipal, estadual } \\
\text { e federal } \\
\text { - Ausência de recursos } \\
\text { financeiros para educação e } \\
\text { pesquisa } \\
\text { - Ausêncla de fiscalização } \\
\text { - Ocupação desordenada } \\
\text { - Omissło do poder } \\
\text { público que permitiu } \\
\text { irregularidades } \\
\text { - Desmatamento para } \\
\text { atividades diversas }\end{array}$ & $\begin{array}{l}\text { - Educação ambiental para } \\
\text { conscientização dos } \\
\text { moradores e restante da } \\
\text { sociedade } \\
\text { - Mobilizaçäo da populaçăo } \\
\text { para sensibilizaçäo e } \\
\text { participação na cobrança ds } \\
\text { autoridades } \\
\text { - Empenho das autoridades } \\
\text { e população no cumprimento } \\
\text { de seus deveres } \\
\text { - Fiscalização efetiva } \\
\text { Uvilizaçăo ampliada da mídia } \\
\text { para denúncias e educaçăo } \\
\text { - Campanhas educativas e } \\
\text { de mobilização } \\
\text { - Divulgação dos trabalhos } \\
\text { realizados pelo Cemasi } \\
\text { - Legislação mais clara e } \\
\text { severa } \\
\text { - Parcerias entre poder } \\
\text { público, empresas privadas, } \\
\text { universidades e cutros }\end{array}$ & $\begin{array}{l}\text { - Equilibrio } \\
\text { - Preservaçäo } \\
\text { - Consolentização da } \\
\text { importâncla da preservação } \\
\text { - Respeito a todas as } \\
\text { formas de vida } \\
\text { - Autoridades } \\
\text { empenhadas na } \\
\text { preservação e conservação. }\end{array}$ \\
\hline
\end{tabular}




\section{PROFESSORES UNIVERSITÁRIOS}

\begin{tabular}{|c|c|c|}
\hline PROBLEMAS & SOLUÇÕES & SONHOS/DESEJOS \\
\hline $\begin{array}{l}\text { - Ausência de vontade } \\
\text { política (municipal, estadual } \\
\text { e federal) } \\
\text { - Ausência de fiscalizaçăo } \\
\text { - Ocupaçäo irregular com } \\
\text { várias consequências: } \\
\text { desmatamentos, espécies } \\
\text { ameaçadas etc. } \\
\text { - Ausência de cobrança da } \\
\text { sociedade para a } \\
\text { preservaçäo e conservação } \\
\text { - Exploraçäo geral como a } \\
\text { caça e extraçăo de plantas } \\
\text { - Problemas sociais } \\
\text { - Ausência de divulgaçăo } \\
\text { dos trabalhos realizados na } \\
\text { Serra do Itapety } \\
\text { - Trabalhos realizados sem } \\
\text { planejamento } \\
\text { - Cemasi muito distante e } \\
\text { restrito, sem divulgaçäo } \\
\text { - Poucos conhecimentos } \\
\text { da biodiversidade existente } \\
\text { - Serra como iliha cercada } \\
\text { pelo urbano que a pressiona } \\
\text { - Universidade com } \\
\text { desempenho deficiente, sem } \\
\text { grandes investimentos na } \\
\text { Serra do Itapety } \\
\text { - Ausência de } \\
\text { investimentos de forma geral } \\
\text { - Visitas ao Parque Natural } \\
\text { Municipal que provocam } \\
\text { impactos negativos para a } \\
\text { biodiversidade } \\
\text { - Queimadas }\end{array}$ & $\begin{array}{l}\text { - Educaçăo ambiental geral } \\
\text { - Trabalhos com a } \\
\text { comunidade buscando sua } \\
\text { participação } \\
\text { - Investimentos por parte } \\
\text { do poder público e do setor } \\
\text { privado } \\
\text { - Universidade mais } \\
\text { atuantes } \\
\text { - Fiscalizaçäo efetiva } \\
\text { podendo ser com motos e } \\
\text { cavalos } \\
\text { - Treinamento de fiscais } \\
\text { - Divulgaç̆o dos trabalhos } \\
\text { realizados } \\
\text { - Formaçäo de núcleos de } \\
\text { educaçäo ambiental e } \\
\text { proteção ao longo da Serra } \\
\text { do Itapety, com a } \\
\text { participaçăo đa comunidade, } \\
\text { poder público e } \\
\text { universidades } \\
\text { - Utilização de projetos já } \\
\text { existentes que se encontram } \\
\text { engavetados } \\
\text { - Democratizaçăo de } \\
\text { informações geradas pelas } \\
\text { pesquisas } \\
\text { - Remanejamento dos } \\
\text { moradores das propriedades } \\
\text { irregulares } \\
\text { - Desernvolvimento de } \\
\text { ecoturismo } \\
\text { - Maior apoio ao Cemasi } \\
\text { - Aprimoramento do } \\
\text { Convênio entre Prefeitura/ } \\
\text { Universidades, buscando } \\
\text { apoio de empresas privadas }\end{array}$ & $\begin{array}{l}\text { - Preservação para futuras } \\
\text { geraç̆es } \\
\text { - Maior apoio e vontade } \\
\text { politica para a preservaçäo } \\
\text { - Ampliaçăo dos trabalhos e } \\
\text { divulgaçäo deles } \\
\text { - Que a Serra do ltapety } \\
\text { faça parte da vida de todos } \\
\text { - Que seja toda desocupada } \\
\text { - Desenvolvimento } \\
\text { sustentável } \\
\text { - Conciliar lazer com a } \\
\text { preservaçăo }\end{array}$ \\
\hline
\end{tabular}




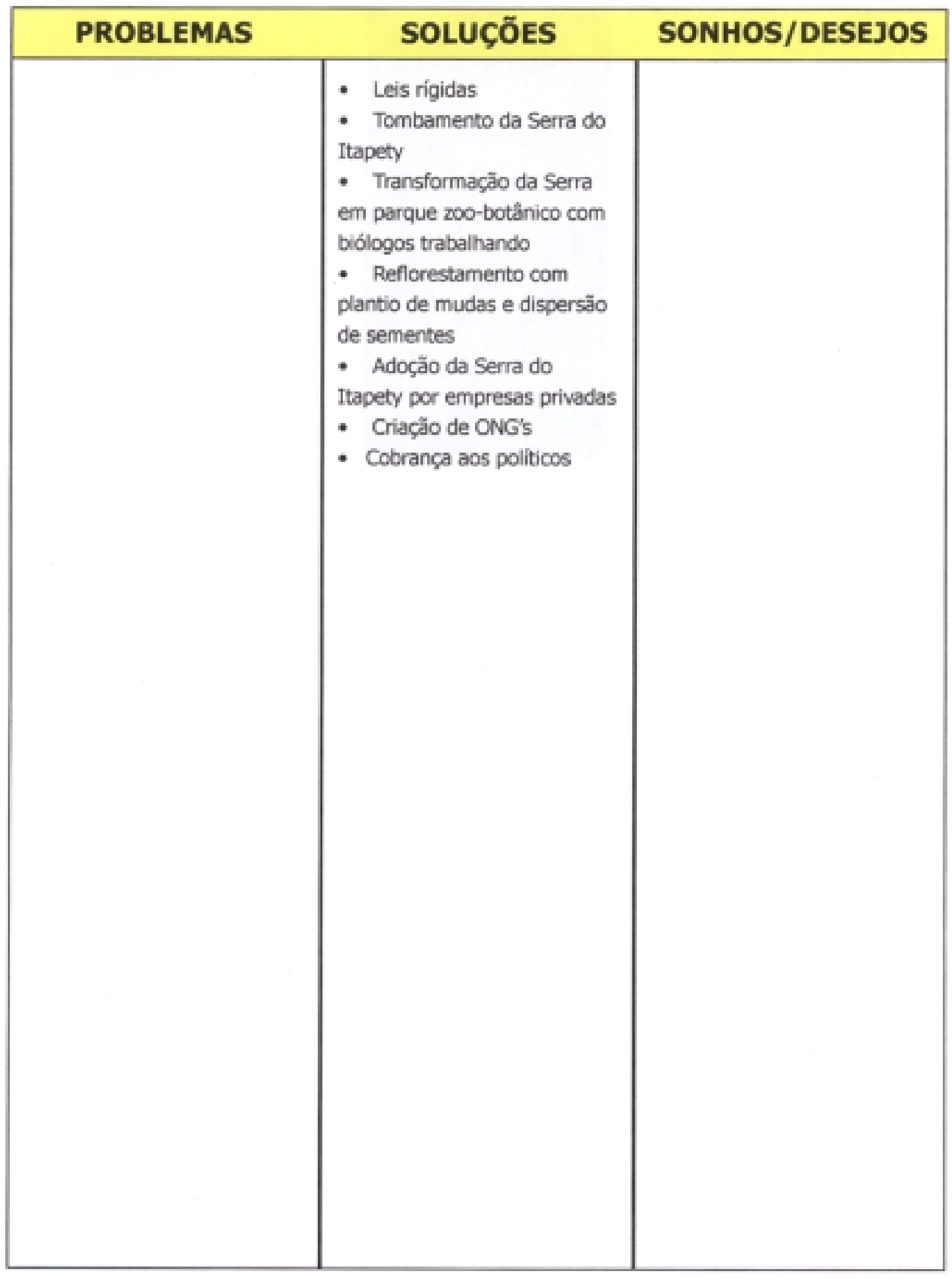




\section{VEREADORES}

\begin{tabular}{|c|c|c|}
\hline PROBLEMAS & SOLUÇÕES & SONHOS/DESEJOS \\
\hline $\begin{array}{l}\text { - Ocupação irregular com } \\
\text { inúmeras consequêtncias } \\
\text { - Austencia de recursos } \\
\text { financeiros } \\
\text { - Omissäo das autoridades } \\
\text { que durante anos permitiram } \\
\text { ocupaçöes irregulares } \\
\text { - Presença de caçadores } \\
\text { - Parque natural Municipal } \\
\text { fechado ou com visitas } \\
\text { restritas } \\
\text { - Ausência de fiscalização } \\
\text { - Especulaçäo imobiliária } \\
\text { - Impacto visual negativo } \\
\text { provocado por inúmeras } \\
\text { antenas e cutras } \\
\text { degradaçöes } \\
\text { - Problemas sociais } \\
\text { - Ausência de } \\
\text { conhecimento dos próprios } \\
\text { vereadores para } \\
\text { norteamento de açöes } \\
\text { - Poder público municipal } \\
\text { sem autonomia } \\
\text { - Face norte da Serra do } \\
\text { Itapety esquecida, tomada } \\
\text { por devastaçöes }\end{array}$ & 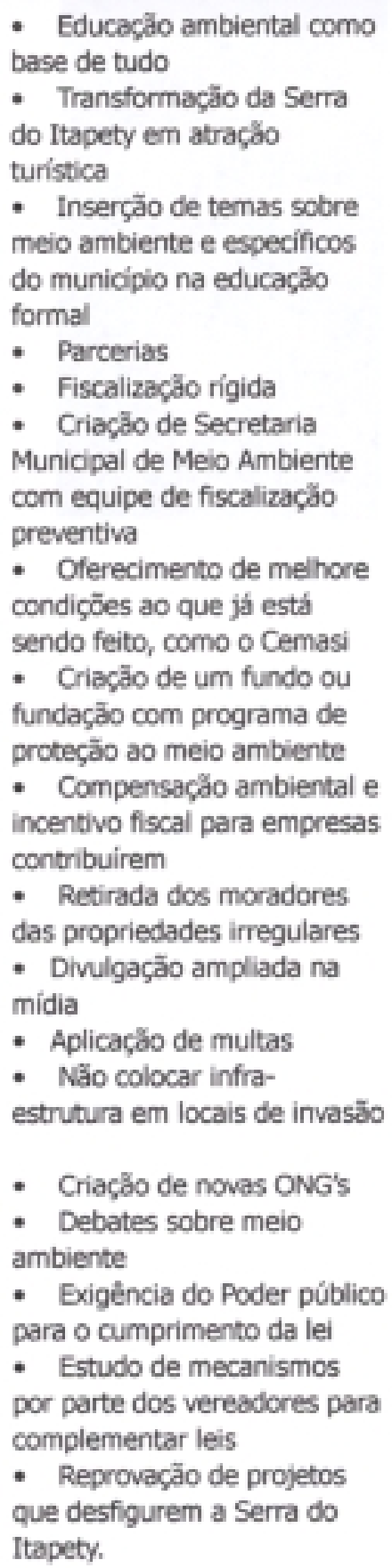 & $\begin{array}{l}\text { - Preservaçäo para futuras } \\
\text { geraç̄es } \\
\text { - Olhar da cidade para a } \\
\text { Serra do Itapety e nắo o } \\
\text { contrário } \\
\text { - Que possamos entender } \\
\text { que a Serra do Itapety é } \\
\text { nosso cartão postal } \\
\text { - Que a Serra faça parte da } \\
\text { vida da populaçăo de forma } \\
\text { coerente com a preservação }\end{array}$ \\
\hline
\end{tabular}




\title{
Anexo $\mathrm{H}$ - Ofício referente à reunião geral para discussão dos olhares sobre a Serra do Itapety.
}

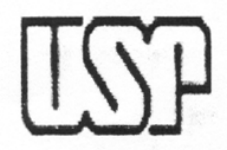

\author{
UNIVERSIDADE DE SÃO PAULO - USP \\ ESCOLA SUPERIOR DE AGRICULTURA LUIZ DE QUEIROZ - ESALQ \\ DEPARTAMENTO DE RECURSOS FLORESTAIS
}

Mogi das Cruzes, 14 de setembro de 2001.

IImo Sr.

José Eduardo Cavalcanti Teixeira

Vereador - Câmara Municipal de Mogi das Cruzes

A Universidade de São Paulo /Escola Superior de Agricultura Luiz de Queiroz através de seu Departamento de Recursos Florestais, vem desenvolvendo o projeto "Educação Ambiental na Serra do Itapety - Construindo uma Agenda 21 local" com a participação da sociedade civil e poder público.

Como parte deste projeto, acontecerá uma reunião entre os segmentos envolvidos com este trabalho objetivando discutir e negociar a Agenda 21 da Serra do Itapety.

Desta forma, temos a honra e satisfação em convidá-lo para participar desta reunião no dia 20 de setembro de 2001 , no período das $13 \mathrm{~h} 30$ às $17 \mathrm{~h} 30$ no Centro de Visitantes do Parque Natural Municipal da Serra do Itapety.

Encontra-se anexo parte do produto "Olhares sobre a Serra do Itapety" base para as discussões da reunião. Outras opiniões, sugestões e comentários serão interessantes para o referido produto, por favor entre em contato.

Sua participação é de extrema importância para o desenvolvimento de nossas reflexões e ações.

Atenciosamente,

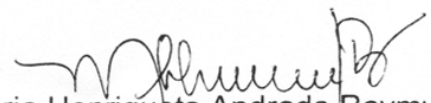

Maria Henriqueta Andrade Raymundo

Responsável Técnica do Projeto

USP/ESALQ

Confirme sua presença, faça sugestões! (11)4791-8109/ email henriquetaandrade@zipmail.com.br

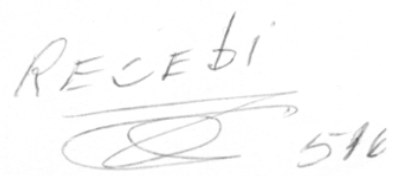


Anexo I - Correspondência sobre confirmação de presença na reunião geral.
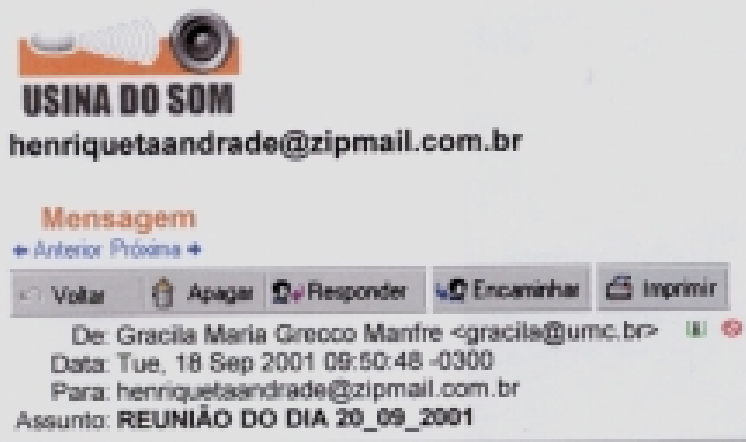
Anexo J - Documento da criação da Comissão da Agenda 21 da Serra do Itapety.

\section{COMISSÃO DA AGENDA 21 DA SERRA DO ITAPETY}

No dia 20 de setembro de 2001, realizou-se no Parque Natural Municipal da Serra do Itapety, reunião entre os diversificados setores da sociedade civil e poder público para discussão do relatório, "Olhares sobre a Serra do Itapety" resultado do projeto "Educação Ambiental na Serra do Itapety / Construindo uma Agenda 21 Local" (USP/ESALQ).

Desta reunião, resultou a criação da Comissão da Agenda 21 da Serra do Itapety com a aprovação de todos os presentes.

Esta Comissão com 17 membros, divididos em coordenação e integrantes, tem os seguintes objetivos:

1. Discutir e avaliar os problemas e sugestões para soluçōes apresentadas pelos diversos segmentos envolvidos no Projeto "Educação Ambiental na Serra do Itapety - Construindo uma Agenda 21 Local";

2. Sistematizar um Plano de Ação ( Agenda 21) para a Serra do Itapety, a partir do relatório "Olhares sobre a Serra do Itapety";

3. Promover ampla reunião/encontro para divulgação, discussão e análise da Agenda 21 da Serra do Itapety;

4. Incorporar e sistematizar outras contribuições, editando nova versão da Agenda 21 da Serra do Itapety;

5. Publicar a Agenda 21 da Serra do Itapety;

6. Coordenar e monitorar a implantação da Agenda 21 da Serra do Itapety.

A seguir coordenação e integrantes desta Comissão:

Coordenação:

Maria Henriqueta Andrade Raymundo

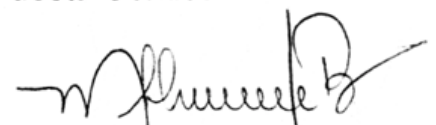

Escola Superior de Agricultura Luiz de Queiroz / Centro de Monitoramento Ambiental da Serra do Itapety

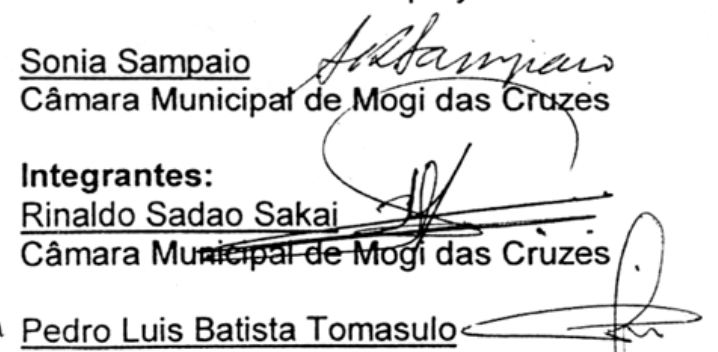

Universidade de Mogi das Cruzes / Uniyersidade Braz Cubas 


\section{Vanda Trettel}

Universidade Braz Cubas

Lourdes Aparecida Martinez

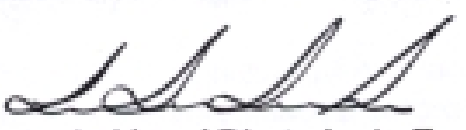

EE Prof. Dr. Rubens Mercadante de Lima / Diretoria de Ensino de Mogi das Cruzes

Vânia Aparecida Gonçalves

EE Isabel F. da Silva /Diretoria de Ensino de Mogi das Cruzes

Marlon de Melo malostat:

Curso de Ciếncias Biológicas da Universidade de Mogi das Cruzes

Cristiandréa Ciciliato

Curso de Ciências Biológicas da Universidade Braz Cubas .

Josemir Ferraz Campos

Secretaria Municipal de Culturare Meio Ambiente - Prefeitura Municipal de Mogi das Cruzes

Erineuda Ventura

Secretaria Municipal de Planejamento e Urbanismo - Prefeitura Municipal de Mogi das Cruzes

Lucila Manzatti leculs $m \operatorname{mon} y / t$

Centro de Monitoramento Ambiental da Serra do Itapety - Cemasi

Conceicąo Aparecida Cardoso Mocaes Amoras

Centro de Monitoramento Ambiental da Serra do Itapety - Cembasi

Ana Maria Abreu Sandim

Instituto dos Arquitetos do Brasil-Regional de Mogi das Cruzes

Rubens Guilhemat

Universidade de Mogi das Cruzes

Heloisa Pomaro

Moradora do entorno da Serra do Itapety

Silvio Pomaro

Morador do entorno da Serra do Itapety

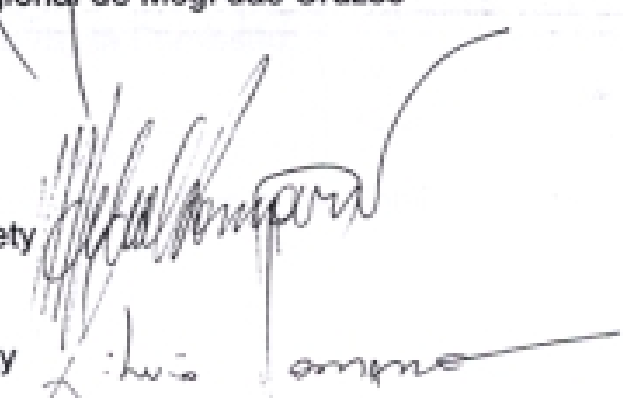




\title{
Anexo K - Ofício sobre a primeira atividade organizada pela Comissão da Agenda 21 da Serra do Itapety.
}

\author{
COMISSÃO EXECUTIVA DA AGENDA 21 DA SERRA DO ITAPETY
}

Mogi das Cruzes, 01 de novembro de 2001.

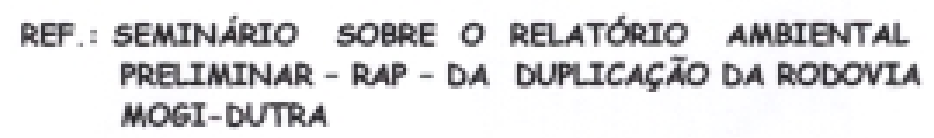

Contamos com sua participação para o seminário acima referido, a ser apresentado pela GEOTEC no dia 09 de novembro próximo, às 14 h., no Auditório Vip do Campus I da Universidade Braz Cubas.

Un trecho da Serra do Itapety é considerado Área de Proteçäo Ambiental - APA -, e qualquer intervençäo nessa área exige estudos de impacto ambiental, o que o DER - Departamento de Estradas de Rodogem -, responsável pelo projeto de duplicação, providenciou junto à GEOTEC, empresa contratoda para a elaboraçăo de um Relatório Ambiental.

Embora a Secretaria Estadual do Meio Ambiente tenha solicitado estudos complementares ao DER, a COMISSÄO EXECUTIVA DA AGENDA 21 Serra do Itapety julga importante que a comunidade mogiana tenha este primeiro contato com as questöes ambientais colocadas no RAP, para que esse assunto passe a ser tratado com maior conhecimento e objetividade.

Desde já, gratas pela presença

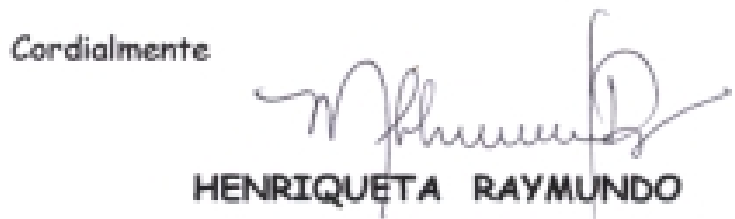

Coordenadoras da

Comissão Executiva da Agenda 21 Serra do Itapety

Ilmo. Sr.

CAETANO ANTONIO CAMARGO

Supervisor de Ensino da Diretoria de Ensino de

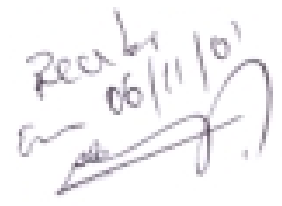
Mogi das Cruzes 


\section{REFERÊNCIAS BIBLIOGRÁFICAS}

AB'SABER, A. A universidade brasileira na conceituação da educação ambiental. Educação brasileira, v.15, n.31, p.107-117, 1993.

ALVES, R. Entre a ciência e a sapiência: o dilema da educação. São Paulo: Loyola, 1999. 148p.

AMARAL, H. K. Políticas públicas em meio ambiente. In: SORRENTINO, M.; TRAJBER, R.; BRAGA, T.(Coord.). Cadernos do III fórum de educação ambiental. São Paulo: Gaia, 1995. p.93-99.

ANTUNIASSI, M. H. R. Educação ambiental e democracia. In: SORRENTINO, M.; TRAJBER, R.; BRAGA, T.(Coord.). Cadernos do III fórum de educação ambiental. São Paulo: Gaia, 1995.

AVANZI, M. R. Educação ambiental e educação para cidadania experiências locais nas bacias dos rios Piracicaba e Capivari. São Paulo, 1998. 148p. Dissertação (Mestrado) - Faculdade de Educação, Universidade de São Paulo.

BARBIER, R. A escuta sensível na abordagem transversal. In: BARBOSA, J. G. (Coord.). Multirreferencialidade nas ciências e na educação. São Carlos: UFSCAR, 1998. p.168-197.

BORDA, F. O. Aspectos teóricos da pesquisa participante: considerações sobre o significado e o papel da ciência na participação popular. In: BRANDÃO, C.R. Pesquisa participante. São Paulo: Brasiliense, 1982. $211 \mathrm{p}$. 
BRASIL. Ministério do Meio Ambiente. Construindo a Agenda 21 Local. Brasília: MMA, 2000. 90p.

BRÜGGER, P. Educação ou adestramento ambiental? São Paulo: Letras contemporâneas, 1994.

CALDEIRA, T. P. D. 0 cotidiano dos moradores da periferia e o que pensam do poder e dos poderosos. São Paulo: Brasiliense, 1984. p.143-288: Imagens do poder e da sociedade.

CASTRO, R. S.; SPAZZIANI, M. L. "Vygotsky e Piaget: contribuições para Educação Ambiental. In: NOAL, F.O.; REIGOTA, M.; BARCELOS, V.H.L. Tendências da educação ambiental brasileira. 2.ed. Santa Cruz do Sul: EDUNISC, 2000. 263p.

COSTA, L. R F. Estratégia de planejamento. Ciência e cultura, v.38, p.1366-1373, 1986.

CRESPO, S. Educar para a sustentabilidade: a educação ambiental no programa da Agenda 21. In: NOAL, F.O.; REIGOTA, M.; BARCELOS, V.H.L. Tendências da educação ambiental brasileira. 2.ed. Santa Cruz do Sul: EDUNISC, 2000. 263p.

DALLARI, D. Direito de participação. In: SORRENTINO, M. (Coord.). Ambientalismo e participação na contemporaneidade. São Paulo: EDUC/FAPESP, 2001. p.85-114.

DEMO, P. Participação e avaliação: projetos de intervenção e ação. In: SORRENTINO, M. (Coord.). Ambientalismo e participação na contemporaneidade. São Paulo: EDUC/FAPESP, 2001. p.163-173.

DEMO, P. Pesquisa e construção de conhecimento: metodologia científica no caminho de Habermas. Rio de Janeiro: Tempo brasileiro, 1994. 125p. 
DIAS, G. F. Educação ambiental: princípios e prática. São Paulo: Gaia, 1994.

ESPINOSA, B. Ética. Trad. de J. Carvalho, J. F. Gomes e A. Simões. 4.ed. São Paulo: Nova Cultural, 1989. 235p.

FERRREIRA, L. C. Sustentabilidade e democracia no poder local. Ambiente e sociedade, v.1, n.1, p.63-78, 1997.

FOUCAULT, M. A verdade e as formas jurídicas. Trad. R. C. M. Machado e E. J. Morais. Rio de Janeiro: Nau, 1999. 160p.

FREIRE, P. Pedagogia do oprimido. Rio de Janeiro: Paz e Terra, 1987.

GONÇALVES, C. W. P. Meio ambiente, ciência e poder: diálogo de diferentes matrizes de racionalidade. In: SORRENTINO, M. (Coord.). Ambientalismo e participação na contemporaneidade. São Paulo: EDUC/FAPESP, 2001. 229p.

GUIMARÃES, R. P. Agenda 21 e desenvolvimento sustentável. Debates Sócio Ambientais, n.11, p.1-3, nov./fev. 1998/1999.

INSTITUTO ECOAR PARA A CIDADANIA. Agenda 21 do pedaço. São Paulo, 1997.

JACOBI, P. R. Educação ambiental para cidadania. In: SÃO PAULO (Estado). Secretaria do Estado do Meio Ambiente / Coordenadoria de Educação Ambiental. Educação, meio ambiente e cidadania: reflexões e experiências. São Paulo, 1998.

JACOBI, P. R. Participação popular e a construção de uma nova institucionalidade. Debates Sócio Ambientais, n.6, p.1-2, fev./mar./abr./maio. 1997.

JUNQUEIRA, A. T. M.; LEITE, L. G. Política municipal do meio ambiente. In: SORRENTINO, M.; TRAJBER, R.; BRAGA, T. (Coord.). Cadernos do III fórum de educação ambiental. São Paulo: Gaia, 1995 p.100-114. 
KELSEN, H. A democracia. São Paulo: Martins fontes,1993.

KRANZ, P. Pequeno guia da agenda 21 local. Rio de Janeiro: Secretaria Municipal do Meio Ambiente SMA/RJ, 1996.

LEFF, E. Ecologia y capital. Barcelona: Siglo Veintuino, 1994.

LUCKESI, C.; BARRETO, E.; COSMA, J. et al. Fazer uma proposta metodológica. São Paulo: Cortez, 1984. 232p.

LÜDKE, M.; ANDRÉ, M.E.D.A. Pesquisa em educação: abordagens qualitativas. São Paulo: E.P.U., 1986.

MAFFESOLI, M. A sociologia como conhecimento de socialidade. In: BARBOSA, J. G. (Coord.). Multirreferencialidade nas ciências e na educação. São Carlos: UFSCAR, 1998. p.98-105.

MANNA DE DEUS, J. R.; MANZATTI, L.; TOMASULO, P. L. B. Plano de manejo Parque Natural Municipal da Serra do Itapety. Mogi das Cruzes: Centro de Monitoramento Ambiental da Serra do Itapety / Universidade Braz Cubas / Universidade Mogi das Cruzes, 1995. 125p.

MINNIMI, N.; POMPÉIA, S. Nossa agenda ambiental. In: Muda o mundo Raimundo: educação ambiental no ensino básico do Brasil. Brasília: WWF, 1997. 188p.

MORIN, E. Os sete saberes necessários à educação do futuro. 2.ed. Brasília: UNESCO, 2000. 115p.

NOVAES, R. C. Desenvolvimento sustentável na escala local: a Agenda 21 local como estratégia para a construção da sustentabilidade. Campinas, 2001. 180p. Dissertação (Mestrado) - Instituto de Filosofia e Ciências, Universidade Estadual de Campinas.

PATTON, M.Q. Qualitative evaluation and research methods. New York: Sage, 1990. 
PREFEITURA DO MUNICÍPIO DE MOGI DAS CRUZES. Plano diretor do município de Mogi das Cruzes Período 1999/2005: plantas e delimitações. Mogi das Cruzes, 1999.

PREFEITURA DO MUNICIPIO DO RIO DE JANEIRO. Secretaria Municipal do Meio Ambiente. Construindo nosso futuro: agenda 21 local, guia do cidadão. Rio de Janeiro, 1996.

RAMOS, L. F. A. Meio ambiente e meios de comunicação. São Paulo: ANNABLUME, 1995. 160p.

REIGOTA, M. Educação Ambiental: autonomia, cidadania e justiça social. Debates Sócio Ambientais, n.7, p.6-7, set. 1997.

SACARDO, G. A. Participação e subjetividade num programa de educação ambiental. São Paulo, 2001. 160p. Tese (Doutorado) - Faculdade de Saúde Pública, Universidade de São Paulo.

SACHS, I. Estratégias de transição para o século XXI: desenvolvimento e meio ambiente. Trad. de M. Lopes. São Paulo: Estudio Nobel, 1993. $103 p$.

SANSOLO, D. G.; MANZOCHI, L. H. Educação escola e meio ambiente. In: SORRENTINO, M.; TRAJBER, R.; BRAGA, T.(Coord.). Cadernos do III fórum de educação ambiental. São Paulo: Gaia, 1995. 226p.

SANTANA, J. E. Democracia e cidadania: o referendo como instrumento de participação política. Belo Horizonte: Del Rey, 1995. cap.2, p.83-86: Referendo e plebiscito.

SANTOS, B. S. Pela mão de Alice: o social e o político na pósmodernidade. 7.ed. São Paulo: Cortez, 2000. 348p.

SÃO PAULO (Estado). Secretaria do Estado do Meio Ambiente. Programa estadual para a conservação da biodiversidade. São Paulo, 1998. 
SÃO PAULO (Estado). Secretaria do Estado do Meio Ambiente. Agenda 21, conferência das Nações Unidas sobre Meio Ambiente e Desenvolvimento. São Paulo, 1992. 383p.

SAWAIA, B. B. Participação social e subjetividade. In: SORRENTINO, M. (Coord.). Ambientalismo e participação na contemporaneidade. São Paulo: EDUC/FAPESP, 2001. p.115-133.

SIRKIS, A. Ecologia urbana e poder local: a agenda 21 local. Rio de Janeiro: Fundação Ondazul, 1999.

SORRENTINO, M. Avaliação de processos participativos. In: SORRENTINO, M. (Coord.). Ambientalismo e participação na contemporaneidade. São Paulo: EDUC/FAPESP, 2001. p.217-223.

SORRENTINO, M. De Tbilisi a Thessaloniki: a educação ambiental no Brasil. In: CASCINO, F.; JACOBI, P.; OLIVEIRA, J.F. de. (Org.). Educação, meio ambiente e cidadania: reflexões e experiências. São Paulo: SMA/CEAM, 1998. 122p.

SORRENTINO, M. Educação ambiental e universidade: um estudo de caso. São Paulo, 1995. 263p. Tese (Doutorado) - Faculdade de Educação, Universidade de São Paulo.

SORRENTINO, M. Educação ambiental: avaliação de experiências recentes e suas perspectivas. In: PAGNOCCHESCHI, B. (Coord.). Educação Ambiental: experiências e perspectivas. Brasília: INEP, 1993. p.7-30.

TASSARA, E. T. O. Ambientalismo e participação na contemporaneidade: reflexões sobre o ciclo de seminários. In: SORRENTINO, M. (Coord.). Ambientalismo e participação na contemporaneidade. São Paulo: EDUC/FAPESP, 2001. p.209-229. 
TASSARA, E. T. O. Utopia e anti-utopia: o ressuscitar da história. In: SOUZA, L.; FREITAS, M. F. O.; RODRIGUES, M. M. P. (Org.). Psicologia: reflexões (im)pertinentes. São Paulo: Casa do Psicólogo, 1998.

TASSARA, E. T. O.; DAMERGIAN, S. Para um novo humanismo: contribuições da psicologia social. Estudos avançados, p.291-316, 1996.

TASSARA, E. T. O. Globalização, paradigmas e utopias: questões de método na pesquisa social contemporânea. Coletâneas ANPEPP, v.1, n.13, p.83-95, set. 1996.

TASSARA, E. T. O. Educação Ambiental: conhecimento e política no contexto da crise ambiental. In: SORRENTINO, M.; TRAJBER, R.; BRAGA, T. (Org.). Cadernos do III fórum de educação ambiental. São Paulo: Gaia, 1995. p.39-43.

TELLES, V. S. Sociedade civil e a construção de espaços públicos. In: DAGNINO, E. (Org.). Os anos 90: política e sociedade no Brasil. São Paulo: Brasiliense, 1994.

THIOLLENT, M. Metodologia de pesquisa ação. São Paulo: Cortez, 1985. $107 p$.

TRAJBER, R.; MANZOCHI, L. H. (Coord.). Avaliando a educação ambiental no Brasil: materiais impressos. São Paulo: Gaia, 1996. 212p.

VIEZZER, M.; RODRIGUES, C. L.; MOREIRA, T. Enfoque de educação popular e gênero; "somos todos sujeitos e não objetos." In: TRAJBER, R.; MANZOCHI, L. H. (Org.). Avaliando a educação ambiental no Brasil: materiais impressos. São Paulo: Gaia, 1996. p.121-152.

VIEZZER, M.; OVALLES, O. (Org.). Manual latino-americano de educação ambiental. São Paulo: Gaia, 1994. 
WEID, N. V. D. A formação de professor em educação ambiental à luz da Agenda 21. In: PÁDUA, S.M.; TABANEZ, M.F. Educação Ambiental: caminhos trilhados no Brasil. Brasília: IPÊ, 1997. 289p.

WEID, N. V. D. et al. 21 perguntas e respostas para você saber mais sobre a Agenda 21 Local. Rio de Janeiro: Comissão pró Agenda 21 Rio de Janeiro, 1996. 